


\section{KYRGYZ REPUBLIC COUNTRY GENDER ASSESSMENT}

DECEMBER 2019 
(C) 2019 Asian Development Bank

6 ADB Avenue, Mandaluyong City, 1550 Metro Manila, Philippines

Tel +632 8632 4444; Fax +63286362444

www.adb.org

Some rights reserved. Published in 2019.

ISBN 978-92-9261-944-2 (print), 978-92-9261-945-9 (electronic)

Publication Stock No. TCS190593-2

DOI: http://dx.doi.org/10.22617/TCS190593-2

The views expressed in this publication are those of the authors and do not necessarily reflect the views and policies of the Asian Development Bank (ADB) or its Board of Governors or the governments they represent.

ADB does not guarantee the accuracy of the data included in this publication and accepts no responsibility for any consequence of their use. The mention of specific companies or products of manufacturers does not imply that they are endorsed or recommended by ADB in preference to others of a similar nature that are not mentioned.

By making any designation of or reference to a particular territory or geographic area, or by using the term "country" in this document, $\mathrm{ADB}$ does not intend to make any judgments as to the legal or other status of any territory or area.

This work is available under the Creative Commons Attribution 3.0 IGO license (CC BY 3.0 IGO)

https://creativecommons.org/licenses/by/3.0/igo/. By using the content of this publication, you agree to be bound by the terms of this license. For attribution, translations, adaptations, and permissions, please read the provisions and terms of use at https://www.adb.org/terms-use\#openaccess.

This CC license does not apply to non-ADB copyright materials in this publication. If the material is attributed to another source, please contact the copyright owner or publisher of that source for permission to reproduce it. $\mathrm{ADB}$ cannot be held liable for any claims that arise as a result of your use of the material.

Please contact pubsmarketing@adb.org if you have questions or comments with respect to content, or if you wish to obtain copyright permission for your intended use that does not fall within these terms, or for permission to use the ADB logo.

Corrigenda to ADB publications may be found at http://www.adb.org/publications/corrigenda.

Notes:

In this publication, "\$” refers to United States dollars, and "Som" to the som of the Kyrgyz Republic.

ADB recognizes "Kyrgyzstan” as the Kyrgyz Republic.

On the cover: ADB-supported projects in the Kyrgyz Republic expand economic opportunities for women, upgrade transport and energy infrastructure, ensure access to water and sanitation for women, and improve the quality of education (ADB Photo Library). 


\section{Contents}

Tables, Figures, and Boxes

Acknowledgments

Abbreviations vii

Executive Summary

I. Introduction 1

A. Purpose of This Report 1

B. Methodology 1

II. Overview of the Country Situation 2

A. Economic and Political Context 2

B. Gender Equality Indicators and Policies in the Kyrgyz Republic $\quad 8$

C. Commitments, Policies, and Mechanisms Promoting Gender Equality 9

D. Gender-Responsive National Documentation and Legislation 9

E. Gender-Responsive Structures and Mechanisms 12

F. Contribution of Civil Society to Gender Equality Policy and Practice 13

G. Contribution of International Development Agencies to Gender Equality 14 Policy and Practice

$\begin{array}{ll}\text { III. Crosscutting Gender Equality Issues } & 15\end{array}$

A. Gender Stereotypes and Sociocultural Norms $\quad 15$

B. Women's Economic Empowerment 16

C. Gender Dimensions of Human Development 20

D. Women's Unpaid Care Work and Time Poverty 27

E. Women's Resistance to External Shocks 28

F. Leadership and Decision-Making $\quad 29$

IV. Mainstreaming Gender in ADB Operations in the Kyrgyz Republic 30

A. ADB Gender Policy 30

B. ADB in the Kyrgyz Republic $\quad 30$

C. Mainstreaming Gender in ADB Priority Sectors in the Kyrgyz Republic 32

V. Lessons and Conclusions

A. Addressing Gender Equality Issues in the Kyrgyz Republic 52

B. Improving Gender Mainstreaming in ADB Priority Sectors 54

References $\quad 56$

Appendix: Gender Entry Points and Design Features in ADB's Priority Sectors $\quad 63$ 


\section{Tables, Figures, and Boxes}

\section{Tables}

1 Composition of Output by Percentage of Gross Domestic Product

2 Human Development Index Ranking for Former Soviet Union Countries in Central Asia, 2018

3 Human Development Index Trends in the Kyrgyz Republic, 2012-2018

4 Gender Inequality Index Ranking for Former Soviet Union Countries in Central Asia, 2018

5 Percentage of Women Employed in Various Sectors, 2012-2016

6 Unemployment among Women and Men, 2012-2016 19

7 Maternal Mortality Ratios for the Kyrgyz Republic, 2012-2016 22

8 Official Figures on Domestic Violence in the Kyrgyz Republic, 2014-2017 24

\section{Figures}

1 Average Gross Domestic Product Growth Rate, 2001-2013

2 Women and Men Employed in the Informal Sector, 2003-2012

\section{Boxes}

1 Bride Kidnapping in the Kyrgyz Republic 23

2 ADB Support for Addressing and Preventing Domestic Violence in Mongolia 26

3 ADB Gender Categories and Requirements for Gender Mainstreaming 31

4 Scaling Up Female-Managed Small and Medium-Scale Enterprises 34

5 ADB Investments in the Transport Sector in the Kyrgyz Republic 36

6 Key Points from ADB Gender and Transport Tool Kit 40

7 ADB Investments in the Energy Sector of the Kyrgyz Republic 41

8 Key Points from Gender and Energy Tool Kit 44

9 ADB Investments in Water and Sanitation Provision in the Kyrgyz Republic 46

10 ADB Investments in Sustainable Natural Water Resources and Resilience 46 


\section{Acknowledgments}

This country gender assessment (CGA) was written by Alyson Brody, international gender expert, with significant research contribution from Luz Lopez Rodriguez, national gender expert.

The CGA was prepared under the Asian Development Bank (ADB) regional technical assistance (RETA) 9088: Strengthening Gender-Inclusive Growth in Central and West Asia. The overall CGA process was supervised and managed by the Central and West Asia Department (CWRD) gender and development team, composed of Mary Alice Rosero (social development specialist on gender and development); Aidai Bedelbaeva and Gulfia Abdullaeva, national implementation consultants of the Kyrgyz Republic Resident Mission; and Leavides G. Domingo-Cabarrubias (technical assistance gender coordinator). Maria Ava Golda Destura and Fritz Tadeo Tuliao provided overall administrative support. Gulkayr Tentieva, a senior economics officer from the Kyrgyz Republic Resident Mission, is also acknowledged for the overall support in facilitating meeting appointments with the staff, the government, nongovernment organizations, and development partners. Luz Lopez Rodriguez, the international gender consultant for the CGA, drafted this report with inputs from the CWRD gender team.

The full support of the CWRD management team made the production of this CGA possible. We express our deep gratitude to Candice McDeigan, Kyrgyz Republic Resident Mission country director; Nianshan Zhang, advisor and head of the Portfolio, Results, Safeguards and Gender Unit; Hong Wei, deputy director general; Sean O'Sullivan, former director general; and Werner Liepach, director general.

We are also grateful for the valuable inputs of sector specialist peer reviewers from the different divisions. They are Sohail Hasnie (principal energy specialist), Energy Division; Rajesh Vasudevan (senior economist, Regional Cooperation and Operations Coordination Division; Laisiasa Tora (economist, Public Management, Financial Sector, and Trade Division); Yuji Miyaki (public management specialist), Public Management, Financial Sector, and Trade Division); Ruoyu $\mathrm{Hu}$ (urban development specialist, Urban Development and Water Division); and Veronica Mendizabal Joffre (social development specialist, gender and development, East Asia Department, and peer reviewer from the Gender Equity Thematic Group).

The team is grateful to the Kyrgyz Republic Resident Mission staff and partners from the government, civil society organizations, and academia who shared data and analysis in a series of individual meetings and group discussions.

We thank for their cooperation the Ministry of Labor and Social Development, Ministry of Statistics, Ministry of Finance, Ministry of Education and Sciences, Agency for Vocational Education, Ministry of Economy, and Ministry of Transport and Roads of the Government of the Kyrgyz Republic. We most appreciate the participation during consultations of the 
representatives from the following international agencies: Food and Agriculture Organization (FAO) of the United Nations, National Democratic Institute (NDI), United Nations Development Programme (UNDP), United Nations Children's Fund (UNICEF), UN Women, United States Agency for International Development (USAID), and World Food Programme (WFP). We are also grateful to the representatives of the University of Central Asia, the American University of Central Asia, and nongovernment organization partners from the Rural Women's Association, the Gender Research Center, and other independent gender consultants who participated in small group and individual consultations. 


\section{Abbreviations}

\begin{tabular}{|c|c|}
\hline $\mathrm{ADB}$ & Asian Development Bank \\
\hline $\mathrm{ADF}$ & Asian Development Fund \\
\hline BPFA & Beijing Platform for Action \\
\hline CAREC & Central Asia Regional Economic Cooperation \\
\hline CCDRWR & Climate Change and Disaster Resilient Water Resources Sector Project \\
\hline CEDAW & Convention on the Elimination of All Forms of Discrimination against Women \\
\hline CGA & Country Gender Assessment \\
\hline $\mathrm{CSO}$ & civil society organizations \\
\hline CPS & Country Partnership Strategy \\
\hline DMC & developing member country \\
\hline EC & European Commission \\
\hline EGM & effective gender mainstreaming \\
\hline EU & European Union \\
\hline GAD & gender and development \\
\hline GAP & gender action plan \\
\hline GBV & gender-based violence \\
\hline GDP & gross domestic product \\
\hline GEN & gender equity as a theme \\
\hline GFP & gender focal point \\
\hline GGGI & Global Gender Gap Index \\
\hline GII & Gender Inequality Index \\
\hline GRB & gender-responsive budgeting \\
\hline HDI & Human Development Index \\
\hline HPP & hydropower plant \\
\hline ICIP & Investment Climate Improvement Program \\
\hline ICT & information and communication technology \\
\hline IOM & International Organization for Migration \\
\hline ISDP & Issyk-Kul Sustainable Development Project \\
\hline IWMP & Issyk-Kul Wastewater Management Project \\
\hline JFPR & Japan Fund for Poverty Reduction \\
\hline $\mathrm{km}$ & kilometer \\
\hline MDG & Millennium Development Goal \\
\hline MFI & microfinance institution \\
\hline MLSD & Ministry of Labor and Social Development \\
\hline MMR & maternal mortality ratio \\
\hline MSME & micro, small, and medium-sized enterprise \\
\hline NAPGE & National Action Plan on Gender Equality \\
\hline NGE & no gender element \\
\hline NGO & nongovernment organization \\
\hline NGS & National Gender Strategy \\
\hline NSC & National Statistical Committee \\
\hline NSDS & National Sustainable Development Strategy \\
\hline PSM & public sector management \\
\hline PVE & primary vocational education \\
\hline
\end{tabular}


RETA regional technical assistance

STEM science, technology, engineering, and mathematics

SESSD Strengthening the Education System Sector Development

SVESDP Second Vocational Education and Skills Development Project

SDG Sustainable Development Goal

SGE some gender elements

SMEs

SVE secondary vocational education

small and medium-sized enterprises

TVET technical vocational education and training

UNDP United Nations Development Programme

WEDP Women's Entrepreneurship Development Program

WID women in development

WRGE women's rights and gender equality

WSS

water supply and sanitation

WUA water users association

WUG water user groups 


\section{Executive Summary}

\section{Economic and Political Context}

The Kyrgyz Republic is a small, landlocked country that shares borders with Kazakhstan to the north, Uzbekistan to the west, Tajikistan to the southwest, and the People's Republic of China to the southeast. The population of the Kyrgyz Republic as of January 2016 was 6.2 million, with about two-thirds living in rural areas. The country was part of the former Soviet Union until 1991, when it became independent and entered a period of transition toward a market-led economy and began to put in place the necessary democratic structures and processes. There have been two revolutions in the Kyrgyz Republic since independence, sparked by anger over corruption in the government-the first in 2005 and the second in 2010. Following the second revolution, the Kyrgyz people voted for the introduction of a new constitution, marking the shift to a parliamentary democracy. Eight successive prime ministers have been elected up to 2018, none remaining in post for long. The current one is Prime Minister Muhammetkaliy Abulgaziyev, an independent politician not affiliated with any political party, who was elected in April 2018.

Following its independence from the former Soviet Union, the Kyrgyz Republic transitioned to a system of economic liberalization. Economic growth has been steady but very slow compared to other neighboring former Soviet Union countries. Economic growth averaged $5 \%$ between 2013 and 2017, but the country's reliance on gold production and exports contributed to sharp fluctuations. From a peak of $10.9 \%$ growth in 2013, external shocks-such as the Russian Federation's economic slowdown-caused a dramatic drop during 2014-2015, with growth dropping to $1.7 \%$ in 2015 . There has been little change in the last 4 years, with average growth of only $4.2 \%$ between 2015 and 2018. According to the World Bank data, the gross domestic product (GDP) was $\$ 6.8$ billion in 2016, compared with $\$ 6.2$ billion in 2011 .

The Kyrgyz Republic fares poorly in terms of global development indicators, compared to other former Soviet Union countries in the region. In 2018, it was ranked 122nd out of 189 countries and territories in the United Nations Development Programme (UNDP) Human Development Index (HDI). The country lags behind its neighbors, such as Kazakhstan, which was ranked 58th in the 2018 HDI; and Uzbekistan, which was ranked 105th.

Around a quarter of the country's total population lives below the poverty line of Som31,151which is equivalent to approximately $\$ 446-$ per capita per year. Extreme poverty is low, however, affecting only $0.8 \%$-around 49,000 -of the population. Women in the Kyrgyz Republic are disproportionately affected by poverty and are worst hit by a reduction in employment opportunities, coupled with a widening gender wage gap. The capacity for women of childbearing age to take on formal employment is also undermined by the withdrawal of state-run systems of family and childcare support. 


\section{International Indicators on Gender Equality}

The Kyrgyz Republic has achieved near gender parity in education enrollment and literacy rates. However, it fares poorly in the key global indicators of women's labor force participation, women's leadership, and maternal mortality ratio. Women's economic participation remains low at $48.2 \%$ compared to $75.7 \%$ for men. Women's political empowerment is also low with only $16 \%$ of seats in the Parliament in 2018. The maternal mortality ratio is extremely high at 76 deaths per 100,000 live births. These persistent areas of gender inequality resulted in a ranking of 91st in a total of 189 countries in the 2017 gender inequality index (GII). The country has an overall composite score of 0.392 based on its progress in the key indicators on maternal mortality, adolescent birth rate, gender parity in secondary education, and political representation. This puts the country behind many other former Soviet Union countries in the region: for example, Kazakhstan is 43rd in the GII, Armenia is 55th, and Uzbekistan is 59 th.

\section{Commitments, Policies, and Mechanisms Promoting Gender Equality}

The Kyrgyz Republic has ratified several key international human rights conventions on human rights and gender equality. These include the Convention on the Elimination of All Forms of Discrimination against Women (CEDAW) on 10 February 1997, and the Optional Protocol of CEDAW (OP-CEDAW) on 22 June 2002. In 2000, the country submitted its first report on the implementation of the CEDAW Convention to the CEDAW Committee.

The Constitution of the Kyrgyz Republic, amended in 2010, enshrines the principles of inalienable human rights and gender equality but fails to recognize discrimination on the grounds of sexual orientation, gender identity, or disability.

The Law "On State Guarantees of Equal Rights and Equal Opportunities for Men and Women" was passed in August 2008. This law is the most significant, comprehensive piece of legislation designed to ensure equality between women and men. The law prohibits acts based on traditional or customary laws that contravene the principles of equality it enshrines. It also sets out provisions for ensuring its effective implementation, including requiring state bodies and local government authorities to submit annual evaluation reports for the systematic collection of statistical data, and for enforcement processes where alleged breaches of the law can be formally reviewed.

The Kyrgyz Republic's first long-term National Gender Strategy (NGS) on Achieving Gender Equality by 2020 was adopted in 2012 in compliance with CEDAW. The NGS outlines the following five pivotal areas for achieving gender equality: (i) strong, effective institutional mechanisms; (ii) economic empowerment; (iii) an education system that promotes gender equality; (iv) access to justice for women; and (v) gender-equitable political participation. The NGS is further elucidated through national action plans on gender equality.

The Gender Policy Department of the Ministry of Labor and Social Development oversees the implementation of the NGS. The National Council for Gender Development was established in May 2012 as an advisory body chaired by the Deputy Prime Minister. It comprises ministers, deputy ministers, and heads of oblasts (provincial governments). 
However, the 2015 CEDAW concluding observations identified weaknesses, including (i) a lack of political will to implement gender commitments, (ii) lack of coordination across the various elements of the national machinery, and (iii) limited capacity and authority of the responsible agencies to implement gender policy. The National Statistics Committee produces and publishes gender statistics, including the annual report, Women and Men in the Kyrgyz Republic.

\section{Key Gender Equality Issues}

\section{Gender Stereotypes and Sociocultural Norms}

Since the country's independence, there has been a resurgence of conservative gender norms. Stereotypes promoted by the state, media, and other actors portray women as primarily mothers and wives, and research indicates that these ideas have influenced thinking among Kyrgyz women and men. Women's presence in public sector roles has also diminished, largely due to the erosion of subsidized childcare facilities. CEDAW has drawn attention to the negative implications of these stereotypes for women's empowerment, to gender-based violence, and harmful practices, such as child marriage and bride kidnapping.

\section{Women's Economic Empowerment}

The economic transition in the Kyrgyz Republic resulted in a huge loss of formal sector jobs, affecting both men and women. Of the total number of people employed in the country, only $25 \%$ are in the formal sector, while $76 \%$ of the economically active population are selfemployed. Women were particularly hit hard. In 1991, 81.6\% of the employed women were in the formal labor force, many were working in public sector institutions, and supported by public state-funded services and provisions that included day care centers, kindergartens, extended maternity leave, and access to basic health care. By 2007, the employment rate for women was almost halved at $42.3 \%$. This was partly due to the loss of these former Soviet Union-era jobs previously occupied by women, and to women's reduced capacity to take up full-time work in the absence of subsidized childcare. In 2018, just over $40 \%$ of the workforce is female, compared to $59 \%$ male. The employment gap is particularly significant for women aged 20-34, who are most likely to leave formal employment to care for young children and infants.

Data show gender segregation in the types of employment undertaken. Women predominate in the following sectors: health and social services-with $83.6 \%$ of the labor force being female; education-80.6\%; and hotels and restaurants $-58.4 \%$. In contrast, highly paid technical sectors are dominated by men. Men account for $84.4 \%$ of employees in the mining industry; $90.5 \%$ in the production of gas, electricity, and water; $89.3 \%$ in the transport and communication sector; and 96.5 in the building industry. The predominance of women in lower-paid sectors is reflected in the considerable gender wage differential, with women receiving on average just $74.3 \%$ of men's earnings in 2012, and $75.3 \%$ in 2016. Aggregate unemployment figures remain high, but women comprise the majority of the unemployed. In 2016, the unemployment rate was $8.7 \%$ for women, compared with $6.2 \%$ for men. 


\section{Gender Dimensions of Human Development}

\section{Education}

The Kyrgyz Republic has a high level of enrollment in education and near gender parity at the primary level. This changes at the secondary level where the number of girls graduating significantly outnumbers that of boys. Enrollment during school year 2013-2014 in upper secondary education comprised $50.2 \%$ boys and $56.7 \%$ girls. The cost of education is likely to be a contributing factor to this gender imbalance, especially in rural areas where families are most likely to withdraw their male (and sometimes female) children to help in the household income.

\section{Violence against Women}

There has been a steep increase in incidences of bride kidnapping (ala kachu) in the 2 decades after independence-despite this practice being officially made illegal in 1994. There is also a growing trend of early marriage, which is partly linked to the practice of bride kidnapping. In $2014,12.7 \%$ of female respondents aged $20-49$ who participated in a national statistical survey said they married, or entered into an unregistered marriage, when they were below the age of 18 .

\section{Domestic Violence}

Domestic violence is widespread and prevalent in the Kyrgyz Republic. Based on government figures, an estimated $23 \%$ of all women aged 15-49 have experienced physical violence at least once. This rises to $28 \%$ for married or formerly married women, with $4 \%$ reporting exposure to sexual violence and $14 \%$ to emotional abuse at the hands of their current or former partners. Of those experiencing abuse, only $39 \%$ had sought assistance. Evidence from women's nongovernment organizations in the country suggests that the actual numbers are far higher as the majority of domestic violence cases go unreported.

The Law on Social and Legal Protection Against Violence in the Family was adopted in 2003. The law sets out the responsibilities of social services in supporting people escaping from domestic violence, and includes measures to prohibit perpetrators from contacting the victim. It also calls for least one shelter space to be provided per 10,000 people. In practice, the implementation of this law has been poor. Few cases were brought to court and state provision of safe houses and shelters for victims was minimal.

In April 2017, a new Law on the Prevention and Protection Against Family Violence replaced the earlier 2003 law. This revised law allows anyone who is aware of domestic violence occurring to report it. In addition to recognizing physical, sexual, and psychological violence, the new law also recognizes economic violence.

\section{Women's Unpaid Care Work and Poverty}

A time budgeting study conducted in 2015 found that, on average, women and adolescent girls spend 4 hours and 30 minutes per day on household chores, which accounts for $18.8 \%$ of their time every day, whereas men and adolescent boys spend only around 1 hour and 20 minutes or 
$6.5 \%$ of their time on these activities. The study indicated that women spend twice the amount of time per day on childcare compared with men. It also indicated that men spend on average less than a third of their time on unpaid domestic work, which is much less than women. Low access to free or subsidized childcare and poor provision of early childhood education exacerbate this burden of unpaid care work, which undermines women's potential to enter the labor market. In 2017 , only $18 \%$ of children who are under 7 years received preschool education.

\section{Women's Resilience to External Shocks}

In the Kyrgyz Republic, climate change and environmental degradation have led to a situation of deteriorating soil quality; water scarcity; and other phenomena such as floods, mudflows, and earthquakes-all of which are having a disproportionate effect on women and girls. For example, women and girls are often the most affected by water shortages, as they need access to water for tasks such as cooking, cleaning, and bathing the children. In times of scarcity, they may restrict their own personal use, which can lead to psychological and physical discomfort during menstruation. The UNDP has reported that women and girls in poorer households are obliged to spend more time collecting water as nearby sources dry up. Evidence also indicates that male farmers have better access to water for irrigation during times of drought. Even though women are often primary users of water, their representation in relevant decisionmaking bodies is generally low. A UNDP study in 2013 found that women accounted for only $18 \%$ of water users association members.

\section{Women's Political Representation}

Women's political representation is relatively low in the Kyrgyz Republic, falling dramatically during the initial period of transition when the former Soviet Union's policy of guaranteeing $33 \%$ women in the Council of People's Deputies was dissolved. After the 2002 elections, women accounted for only 6.7\% of deputies in the Kyrgyz Republic Parliament (Jogorku Kenesh). By 2005, the Parliament was solely composed of men. The adoption of a mandatory gender quota of $30 \%$ in the revised Election Code in 2007 and 2011 helped improve women's representation in elected office at national and local levels. In 2017, women accounted for $19.2 \%$ parliamentarians in the Jogorku Kenesh. Despite a considerable increase in female political representation, the number of women in office has not yet reached the $30 \%$ threshold identified by the Beijing Platform for Action (BPFA) as critical for effective participation in decision-making.

\section{Gender Mainstreaming in ADB Sectors}

ADB has supported sustainable development efforts in the Kyrgyz Republic since 1994. Its previous Country Partnership Strategy (CPS), 2013-2017, which is reviewed in the second section of the report, focused on five key sectors: public sector management, transport, energy, water and sanitation, and education. The CPS identified actions to support the implementation of the government's NGS, with a focus on increasing women's economic opportunities-which includes through education and skills training. It also highlighted the expected impacts of improved transport and energy infrastructure for women and men, and the benefits of better water and sanitation for women-such as reduction in time poverty 
because of more readily available water sources. The recently introduced CPS 2018-2022 pledges to reduce inequalities by promoting job diversification and women's entrepreneurship and improving the quality of secondary and higher education.

A number of programs in the CPS 2013-2017 included gender-responsive elements leading to emerging positive impacts in the target sectors and communities. Good gender practices are evident in the majority of ADB-funded public sector management programs, which recognized the need to create an enabling environment for female entrepreneurs and to boost women's employment as part of a broader economic growth strategy. ADB also contributed considerably to potentially gender transformative approaches in the Kyrgyz education sector. Examples include initiatives revising school curricula and promoting gender awareness among teaching staff, which address gender biases and stereotyping. Other programs are encouraging girls to study science, technology, engineering, and mathematics (STEM) and other nontraditional subjects to increase their employment opportunities.

There are clear examples of gender mainstreaming in the water and sanitation sector, particularly in projects focused on sustainable natural water resources. These include the participatory approach to reflect the voices and needs of diverse male and female end users.

Improved household access to energy is likely to have reduced the burden of unpaid care work for many women by reducing the time and effort needed to collect traditional fuel. The move away from fossil fuels in households should also help reduce the risk of respiratory illnesses and other conditions. However, there is a lack of verifiable gender impact data for the energy sector. Transport programs, including the Central Asia Regional Economic Cooperation (CAREC) -which is rehabilitating major transport corridors within the Central Asia region-had not included any gender elements at the time of this review. However, this should change with the recent introduction of a comprehensive gender action plan, which is designed to ensure gender-responsive project planning and implementation. 


\section{Introduction}

\section{A. Purpose of This Report}

The Asian Development Bank (ADB) has been operational in the Kyrgyz Republic since 2000, working closely in partnership with the government in areas that include public sector management, water and sanitation, transport, energy and energy. ADB takes a gender-integrated approach to all its work, to ensure the programs it funds meet the specific needs of both women and men, and-where possible-contribute toward the achievement of broader gender equality goals. As part of the gender mainstreaming process, $\mathrm{ADB}$ commissions country gender assessments (CGAs) to map key gender equality issues and concerns across multiple areas, with a focus on the sectors that are supported through ADB funding. This is the second CGA for the Kyrgyz Republic, following the first one that was published in 2005.

Part two of this CGA provides a comprehensive, up-to-date gender analysis of key socioeconomic areas and issues for the yrgyz Republic, including equality of rights, political representation and voice, economic opportunities and employment, education, health, violence against women, climate change adaptation, and women's time poverty. Part three is focused on the six core sectors for ADB support as outlined in its previous Country Partnership Strategy (CPS) for 2013-2017. The section reviews progress and identifies gaps in gender mainstreaming and provides key recommendations for each sector to inform future planning.

The report will be of primary interest to ADB staff and partners in the Kyrgyz Republic and the Central Asia region, but it is also relevant to a wide range of other development actors who are designing or undertaking projects in the country and region.

\section{B. Methodology}

This report is based on a comprehensive desk review of the latest statistical data and qualitative research on gender and development in the Kyrgyz Republic. It also benefits from primary information during key informant interviews and focus group discussions with a wide range of stakeholders-including ADB's implementing partner agencies and ministries, and relevant ADB staff (Appendix 1). 


\section{Overview of the Country Situation}

\section{A. Economic and Political Context}

The Kyrgyz Republic is a small landlocked country with a land area of about 200,000 square kilometers. It borders Kazakhstan to the north, Uzbekistan to the west, Tajikistan to the southwest, and the People's Republic of China to the southeast. The country is characterized by mountainous terrain, with $90 \%$ of the territory being more than 1,500 meters above sea level (Scalise and Undeland 2016). The country comprises nine administrative divisions; seven provinces (oblasts)-Batken, Jalal-Abad, Issyk-Kul, Naryn, Osh, Talas, and Chui; and two administratively independent cities-the capital, Bishkek, and the second largest city, Osh. The country's population as of January 2016 was 6.2 million, with around two-thirds living in rural areas. ${ }^{1}$ The rural population live in 453 rural municipalities (or ail aimak), which comprise 1,884 villages. Of the urban population, around $60 \%$ live in the cities of Bishkek and Osh (Dyldaev 2017). There are three levels of governance in the Kyrgyz Republic: national, provincial (oblast), and local self-government (FAO 2016).

The country is very ethnically diverse. Ethnic Kyrgyz accounts for $73.5 \%$ of the total population, while $14.7 \%$ are Uzbek and $5.5 .0 \%$ are of Russian origin. Other smaller ethnic minorities include Dungans (1.1\%), Uighurs (0.9\%), Tajiks (0.9\%), Turks (0.7\%), Kazakhs (0.6\%), and Tatars (0.5\%) (NSC 2016a). Approximately 75\% of the population is Muslim, the majority of whom are Sunni. Around $20 \%$ are Russian Orthodox and the remaining $5 \%$ belongs to minority religious groups (Equal Rights Trust 2016). The Kyrgyz Republic was part of the former Soviet Union until 1991 when it became independent and entered a period of transition toward a market-led economy and began to put in place the necessary democratic structures and processes.

The run-up to independence was marked by economic instability and political turmoil. In 1990, ethnic tensions escalated between the Kyrgyz and Uzbeks around the city of Osh, which resulted in hundreds of deaths, followed by a state of emergency. A period in 1990 also saw anti-communist government protests led by the Kyrgyzstan Democratic Movement. These resulted in the election of a reformist president, Askar Akayev, whom the State Emergency Committee in Moscow made an unsuccessful attempt to depose in 1991. On 31 August 1991, the Supreme Soviet declared the Kyrgyz Republic's independence from the Soviet Union. Presidential elections resulted in the formal election of Akayev, who went on to win further elections in 1995 and 2000. ${ }^{2}$ Large-scale protests over high energy prices and alleged vote rigging in 2005, known as the Tulip Revolution, resulted in the end of Akayev's presidency. Akayev was replaced by Kurmanbek Bakiyev, one of the leaders of the opposition-the People's

1 Figures are as of 2016. See World Bank. 2016. Kyrgyz Republic. https://data.worldbank.org/country/kyrgyzrepublic (accessed October 2018).

2 The democratic nature of the elections is in question. Akayev was the only presidential candidate in the first formal election and was accused of ballot rigging by United Nations observers (ADB 2005). 
Movement of Kyrgyzstan. A period of protracted instability ensued, and a second revolution sparked in 2010, culminating in the President's resignation and the formation of an interim government headed by the former Foreign Minister Roza Otunbayeva, who was part of the opposition party. In May 2010, Otunbayeva became the transition president of the country for a period designated by a special decree of the Interim Government of the Kyrgyz Republic.

Under the interim president, the Kyrgyz people voted for the introduction of a new constitution, which would shift power in the country toward a parliamentary democracy. ${ }^{3}$ The new constitution was introduced in July 2010, and under its auspices, the Kyrgyz Republic became a sovereign state governed by the rule of law. Under Article 1 of the Constitution of the Kyrgyz Republic, the authority to act on the behalf of the people rests solely on the president and the Parliament. The Parliament-the Jogorku Kenesh-is composed of 120 deputies who are elected for 5 -year terms through a system of proportional representation. After the introduction of the constitution in 2010, the first parliamentary election took place and a coalition of three parties was formed, headed by Parliamentary Speaker Akhmatbek Keldibekov. A member of the Social Democratic Party of Kyrgyzstan and a parliamentary deputy-Almazbek Atambayev-was voted president in 2011. Eight successive prime ministers have followed, none remaining in post for long. The current Prime Minister is Muhammetkaliy Abulgaziyev, an independent politician not affiliated with any political party, who was appointed in April 2018.

\section{Socioeconomic Context}

Following its independence from the former Soviet Union, the Kyrgyz Republic embraced policies underpinned by principles of economic liberalization. In the early 1990s, the government undertook reforms that included an ambitious privatization program. Many stateowned enterprises were closed or sold, and the number of people working for government organizations decreased considerably (Ibraeva, Moldosheva, and Niyazova 2011). By 1994, nearly all services were registered to private owners (ADB 2014a).

However, the country experienced a far-from-smooth transition to a market-based economy. Soon after leaving the former Soviet Union, the country's economy dipped sharply into a deep recession. Unemployment increased dramatically due to the sudden introduction of macroeconomic reforms to open the economy to foreign trade and privatize state assets, coupled with the loss of subsidies and intra-country trade from the Russian Federation (Equal Rights Trust 2016). The average GDP growth rate between 2001 and 2013 was only $4.4 \%$, the lowest growth rate when compared to other former Soviet Union countries in the region (Figure 1).

Between 2013 and 2017, growth averaged 5.5\%, driven mainly by gold production and exports, but there were sharp fluctuations during this period (ADB 2018a). According to World Bank data, the GDP was $\$ 6.8$ billion in 2016, compared with $\$ 6.2$ billion in 2011 (World Bank, n.d.c). Factors contributing to this disappointing performance have been the breakdown in trade in goods with other former Soviet Union states, the withdrawal of state subsidies, political instability, and the volatility of gold prices. The country's geographical location, miles

3 This period was marked by violence instigated by supporters of Bakiyev in alliance with local criminals, which targeted the Uzbek population in Osh and Jalal-Abad. Hundreds died, mostly Uzbeks, and hundreds of thousands more were displaced as a result (Equal Rights Trust 2016). 
Figure 1: Average Gross Domestic Product Growth Rate, 2001-2013

$(\%)$

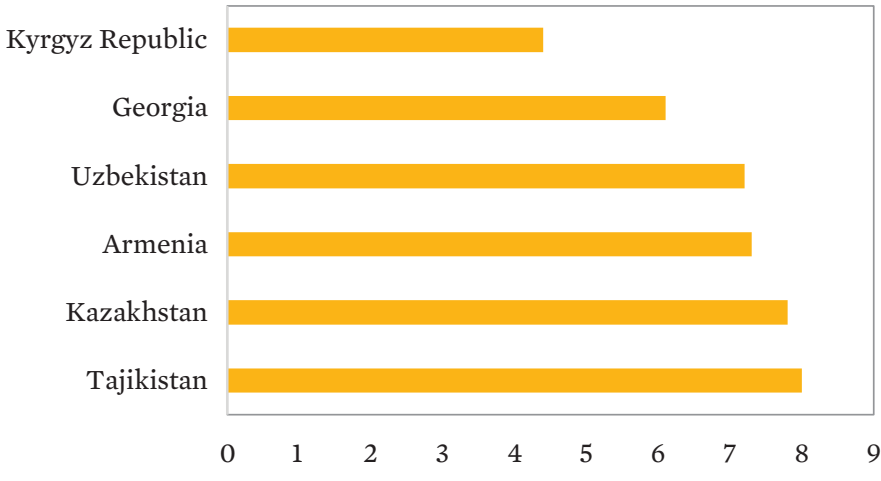

Source: Adapted from ADB. 2014a, p. 11.

away from any seaport, coupled with its lack of natural resources, compound the country's susceptibility to both external and internal shocks.

The structure of the economy is dominated by services, industry, and agriculture, as shown in Table 1 (ADB 2017b). Despite the relatively small contribution to the economy-only $14 \%$ in 2016-agricultural sector is crucial as a source of employment, income, and food security for the large rural population (Scalise and Undeland 2016).

\section{Table 1: Composition of Output by Percentage of Gross Domestic Product} (at current basic prices)

\begin{tabular}{|llllll|} 
& 2012 & 2013 & 2014 & 2015 & 2016 \\
\hline Agriculture & 18.5 & 16.4 & 16.6 & 15.4 & 14.0 \\
Industry & 24.5 & 27.6 & 25.5 & 27.5 & 28.3 \\
Services & 57.0 & 56.0 & 57.8 & 57.1 & 57.3 \\
\hline
\end{tabular}

Source: ADB (2017b).

The Kyrgyz Republic also fares poorly in terms of other global development indicators, compared to other former Soviet Union countries in the region. In 2018, it was ranked 122nd out of 189 countries and territories based on a Human Development Index (HDI) score of 0.67 in 2018, a rise of only 2 percentage points since 2012. This HDI ranking places the country in the category of medium human development. The country lags behind its neighbors: Kazakhstan, which was ranked 58th in the 2018 HDI; and Uzbekistan, which was ranked 105th (ADB 2017b). 


\section{Table 2: Human Development Index Ranking for Former Soviet Union Countries in Central Asia, 2018}

\begin{tabular}{lcl} 
Country & HDI Ranking & \multicolumn{1}{c}{ Status } \\
Kazakhstan & 58 & Very high human development \\
Georgia & 70 & High human development \\
\hline Azerbaijan & 80 & High human development \\
Armenia & 83 & High human development \\
Uzbekistan & 105 & High human development \\
Turkmenistan & 108 & High human development \\
Kyrgyz Republic & 122 & Medium human development \\
Tajikistan & 127 & Medium human development
\end{tabular}

HDI = Human Development Index.

Source: UNDP (2018b).

The HDI measures progress in three basic dimensions of human development-a long and healthy life, access to knowledge, and a decent standard of living. Life expectancy in the Kyrgyz Republic increased by 1 year from 69.7 in 2012 to 71.7 years in 2018. The expected years of schooling remained constant at around 13 , while the gross national income per capita increased from 1.766 to 3.255 (UNDP 2018a).

Table 3: Human Development Index Trends in Kyrgyz Republic, 2012-2018

\begin{tabular}{|lccccc|} 
Year & $\begin{array}{c}\text { Life Expectancy } \\
\text { at Birth }\end{array}$ & $\begin{array}{c}\text { Expected Years } \\
\text { of Schooling }\end{array}$ & $\begin{array}{c}\text { Mean Years } \\
\text { of Schooling }\end{array}$ & $\begin{array}{c}\text { GNI per Capita } \\
(2011 \text { PPP\$) }\end{array}$ & HDI Value \\
\hline 2012 & 69.7 & 12.5 & 10.7 & 1.766 & 0.647 \\
\hline 2013 & 70.2 & 12.8 & 10.7 & 2.975 & 0.656 \\
\hline 2014 & 70.6 & 13.0 & 10.8 & 3.055 & 0.662 \\
\hline 2015 & 70.8 & 13.0 & 10.8 & 3.097 & 0.664 \\
\hline 2016 & 71.0 & 13.4 & 10.9 & 3.113 & 0.669 \\
\hline 2017 & 71.1 & 13.4 & 10.9 & 3.255 & 0.672 \\
\hline 2018 & 71.1 & 13.4 & 10.9 & 3.255 & 0.672 \\
\hline
\end{tabular}

GNI = gross national income, HDI = Human Development Index, PPP = purchasing power parity. Source: UNDP (2018a). Accessed October 2018.

\section{Migration}

Labor migration and foreign remittance is a significant feature of the Kyrgyz economy. In 2014, the remittances sent home by Kyrgyz migrants crossed the $\$ 2$ billion mark, an amount equivalent to $27.4 \%$ of the GDP and almost nine times greater than foreign direct investment (FDI) inflows. This made the country the second most remittance-dependent economy in 2014 (World Bank 2017, p.1). There are no accurate statistics of outbound Kyrgyz migrants but recent data derived from the labor force module of the Kyrgyz Integrated Household Survey suggest that the number of Kyrgyz migrants abroad is around 200,000, which is equivalent 
to $3.3 \%$ of the total population or $10 \%$ of the working age population (World Bank 2017). Young, educated migrants are often driven to leave the country due to a lack of domestic opportunities and economic deprivation.

Gender-specific trends are associated with migration. External migrants are predominantly young males-75.6\% are between ages 18 and 35, with many originating from the poorer regions in the South. By contrast, women represent the majority of migrants moving within the country, often from remote areas to cities. Although $89 \%$ of recorded migrants have completed secondary school, data indicate that many are unemployed or engaged in low paid work in agriculture, sales, or construction prior to departure (World Bank 2017).

\section{Poverty}

There was a sharp rise in poverty after the country gained independence. The period between 2005 and 2009 saw a steady decline in poverty from $43.1 \%$ to $31.7 \%$, but rates began to increase as a result of the political instability and violence (FAO 2016), ${ }^{4}$ reaching $38 \%$ in 2012 (ADB 2014a). ${ }^{5}$ The poverty rate has since dropped and was $25.4 \%$ in 2017 (ADB 2018a). This means that around a quarter of the total population of the Kyrgyz Republic lives below the poverty line of Som $31,151^{6}$ per year per capita. Extreme poverty ${ }^{7}$ is low, however, affecting only $0.8 \%$ or some 49,000 of the population (World Bank 2017), 74\% of which live in rural areas (ADB 2018a). Poverty has clear geographical dimensions-there are wide economic disparities between the capital Bishkek, Chui oblast, and Issyk-Kul oblast, and the rest of the country (ADB 2014a).

However, economic indicators alone cannot reflect the complex human picture of poverty in the country. According to the UNDP 2018 Global Multidimensional Poverty Index, even Kyrgyz people living above the income poverty line may experience deprivations in education, access to health care, and living conditions (UNDP 2016b).8 Factors such as the erosion of social capital and the breakdown of kinship support networks have also compounded poverty, particularly for those living in rural areas because family members and friends often migrate elsewhere (Kuehnast and Dudwick 2002). The considerable reduction of social welfare and loss of state-run services, such as health care and childcare that were provided under the former Soviet Union system also had adverse effects for many, especially for women.

\section{Feminization of Poverty}

Women in the Kyrgyz Republic have been disproportionately affected by poverty in the transition to a market economy. There was a marked reduction in employment opportunities for women due to factors that include widespread unemployment, the loss of bureaucratic roles occupied mainly by women during the former Soviet Union period. The capacity for women of childbearing age to take on formal employment has also been undermined by the withdrawal of the state-run systems of family and childcare support that were an integral

4 Entrepreneurs, such as petty traders and farmers, were badly hit because of security issues that prevented them from traveling.

5 See also NSC of the Kyrgyz Republic and the World Bank's Kyrgyz Republic Country Profile.

6 Approximately \$446 (https://www.xe.com/currencyconverter/. Accessed 17 November 2018).

7 Those that are unable to afford a minimum food basket estimated at Som17,052 per year per capita, which is approximately $\$ 446$ (https://www.xe.com/currencyconverter/. Accessed 17 November 2018).

8 See also the 2018 Global Multidimensional Poverty Index. http://hdr.undp.org/en/2018-MPI (accessed October 2018). 
part of the communist system. This situation, coupled with a widening gender wage gap for women in employment, contributed to increased income poverty for women. Households with female heads are among those most susceptible to poverty. An increasing trend of such households emerged due to the high level of male labor migration. According to the National Statistical Committee (NSC) of the Kyrgyz Republic, the percentage of households with female heads was approximately $36.7 \%$ in 2017 (NSC 2017).

\section{Climate Change}

The Kyrgyz Republic is a country that is at high risk from the adverse effects of climate change. Over the last few decades, the country experienced an increase in climate-induced disasters caused by phenomena, such as floods and drought, and this trend is likely to continue as temperatures increase.

The country ratified the United Nations Framework Convention on Climate Change in 2000 and the Kyoto Protocol in 2003. Between 2001 and 2005, inventories of anthropogenic greenhouse gas emissions were conducted among the eight oblasts. Four National Communications were submitted to the United Nations Framework Convention on Climate Change between 2003 and 2018. The country also made progress in dealing with extreme events and managing natural resources, as demonstrated by government strategies that include the following:

- The 2001-2010 Comprehensive Development Framework, which established strategic socioeconomic development goals and is focused on the sustainable management of natural resources.

- The National Framework Program on Land Resources Management for 20062016, drafted under the Central Asian Countries Initiative on Sustainable Land Management, which is focused on land degradation and sustainable land and water resource management.

- A package of measures to ensure environmental security of the Kyrgyz Republic, which indicate the need for research on the condition of glaciers.

- The development of a Climate Profile of the Kyrgyz Republic (UNDP 2013).

- The development of a National Climate Change Adaptation Program and Action Plan, 2015-2017, with a set of priorities that was updated to $2020 .^{9}$

- The Law on Protection of the Population and Territories from Natural and Man-made Emergency situations, which is focused on reducing the loss of life and injuries, and the economic and social impacts of future events.

\section{The National Sustainable Development Strategy}

In January 2013, the president of the Kyrgyz Republic approved the National Sustainable Development Strategy (NSDS), 2013-2017, the first under the new political system (NCSD 2013). The strategy is guided by a vision, which sets out the need for a unified public consensus on the future of the country, clearly defined targets, and a shared set of values for the country. The strategy highlights the need to protect the rights, freedoms, and security of the population; and the importance of robust economic growth underpinned by a respect for the rule of law, high-quality education, a "healthy natural environment," and public stability.

9 See also the Priorities for Adaptation to Climate Change in the Kyrgyz Republic until 2017 (updated to 2020). 
The strategy recognizes persistent poverty and regional disparities as key challenges and establishes key objectives to achieve a successful, stable democracy and stable growth in GDP and household incomes. It directly addresses the causes of instability, focusing on issues that include promoting the rule of law, facilitating good governance, creating national unity, and ensuring ethnic integration. The NSDS (2018-2040) was approved in November 2018.

\section{B. Gender Equality Indicators and Policies}

\section{International Indicators on Gender Equality}

Gender equality global reports from 2017-2018 indicate a dramatic downward trend in gender equality and women's empowerment in the Kyrgyz Republic. ${ }^{10}$ In the 2017 World Economic Forum Global Gender Gap Index (GGGI) it ranked 85th of 144 countries, falling from an overall GGGI ranking of 52 in 2006 mainly due to a notable reduction in economic participation and opportunities for women (WEF 2017). ${ }^{11}$ It ranked 91st of 189 countries in the 2017 UNDP Gender Inequality Index (GII). ${ }^{12}$ This puts the Kyrgyz Republic well behind many other former Soviet Union countries in the region (Table 4).

\section{Table 4: Gender Inequality Index Ranking for Former Soviet Union Countries in Central Asia, 2018}

\begin{tabular}{|cc|}
\hline Country & Ranking \\
\hline Kazakhstan & 43 \\
\hline Armenia & 55 \\
\hline Uzbekistan & 59 \\
Tajikistan & 69 \\
\hline Azerbaijan & 71 \\
\hline Georgia & 78 \\
\hline Kyrgyz Republic & 91 \\
\hline
\end{tabular}

Source: UNDP (2018b). Accessed October 2018.

Gender inequalities are starkly evident in the key indicators of women's labor force participation, women's leadership, and maternal mortality ratio (MMR). According to the latest GII figures for 2018 (UNDP 2018b), women's economic participation remains low at $48.2 \%$ compared to $75.7 \%$ for men, and demonstrates a downward trajectory, falling from $56 \%$ in 2014 . Women's political empowerment also scored low, with only $19.2 \%$ of seats in Parliament occupied by women in 2017 (UNDP 2018b), ${ }^{13}$ a drop from $23.3 \%$ in 2014 (UNDP 2018a). The MMR remains worryingly high at 76 deaths per 100,000 live births, compared

10 These were the most recent available figures at the time of writing the report in 2018.

11 WEF (2017, p.3). The Global Gender Gap Index was first introduced by the World Economic Forum in 2006 as a framework for capturing the magnitude of gender-based disparities and tracking their progress over time. The GGGI benchmarks national gender gaps on economic, education, health, and political criteria; and provides country rankings that allow for effective comparisons across regions and income groups.

12 UNDP (2018a). The GII maps progress against gender-disaggregated indicators relating to maternal mortality, women's leadership, secondary education, and labor force participation.

13 The number of seats fell to $16 \%$ in 2018. 
to 32 in Tajikistan, 36 in Uzbekistan (UNDP 2018b), and fewer than 10 in many European countries. However, there is relative gender parity in education enrollment and literacy rates. A slight increase in the GII value from 0.35 in 2014 to 0.39 in 2017 mainly reflects an overall increase in secondary education enrollment for both boys and girls. According to the GII, almost $99 \%$ of both girls and boys received some secondary school education (UNDP 2018b).

\section{Commitments, Policies, and Mechanisms Promoting Gender Equality}

\section{International Gender-Responsive Commitments}

The Kyrgyz Republic has ratified several key international human rights conventions on human rights and gender equality, notably the Convention on the Elimination of All Forms of Discrimination against Women (CEDAW) on 10 February 1997, and the Optional Protocol of CEDAW (OP-CEDAW) on 22 June 2002. ${ }^{14}$ In 2000, the country submitted its first report on the implementation of the Convention to the CEDAW Committee. The second periodic report was presented to the committee in January 2004, the third in 2008, and the fourth was submitted in 2015. In 1995, the country became a signatory to the BPFA that served as basis for its national strategy on gender equality (UNDP 2016d).

The country also has specific obligations under Article 3 of the International Covenant on Civil and Political Rights, and Article 3 of the International Covenant on Economic, Social and Cultural Rights to ensure the enjoyment of equal rights by both men and women as set forth in the covenants (Equal Rights Trust 2016).

A government resolution in December 2015 established the Coordinating Committee for Sustainable Development Goal (SDG) Adaptation, Implementation and Monitoring to year 2030 to address the issues of coordination and harmonization of statistical data and other information. An interagency working group, led by the NSC, is now working on integrating the indicators of the SDGs into the national development plan and a statistical monitoring and reporting system is being developed. Prior to committing to the SDGs, the country has committed to the achievement of the Millennium Development Goals (MDGs).

\section{Gender-Responsive National Documentation and Legislation}

\section{Constitution of the Kyrgyz Republic}

The Constitution of the Kyrgyz Republic (Government of the Kyrgyz Republic 2010), adopted in 2010 following the referendum, replaces the previous Constitution of 1993. The preamble states that the Constitution aims to "build a free and democratic state based on respect and the protection of human rights." The Constitution enshrines the principles of inalienable

14 UN Human Rights Office of the High Commissioner. n.d. UN Treaty Body Database. http://tbinternet.ohchr. org/_layouts/TreatyBodyExternal/Treaty.aspx?CountryID=93\&Lang=EN, (accessed 6 October 2017). 
human rights and gender equality in Article 16, which states that "No one may be subject to discrimination on the basis of sex, race, language, disability, ethnicity, belief, political and other convictions, education, background, proprietary, and other status as well as other circumstances." It also states that "...women and men shall have equal rights and freedoms and equal opportunities for their realization." 15 However, Article 16 of the Constitution fails to recognize discrimination on the grounds of sexual orientation, gender identity, or disability (NSC 2017).

\section{Law on Equal Rights and Opportunities for Women and Men}

The law "On State Guarantees of Equal Rights and Equal Opportunities for Men and Women" (hereafter referred to as the Gender Equality Law) was passed in August 2008. This law is the Kyrgyz Republic's most significant, comprehensive piece of legislation designed to ensure equality between women and men. It provides a definition of discrimination in the public and private spheres. ${ }^{16}$ It sets out provisions to ensure the equality of rights, opportunities, obligations and responsibilities in governance, social relations, employment, service provision-including health and education-and other areas.

The Gender Equality Law also prohibits acts based on traditional or customary laws, which contravene the principles of equality that it enshrines. It is also significant that this law sets out provisions for ensuring its effective implementation, including requiring state bodies and local government authorities to (i) submit annual evaluation reports, (ii) implement the systematic collection of statistical data, and (iii) institute processes of enforcement where alleged breaches of the law can be formally reviewed. However, the lack of information on discrimination cases brought before the court makes it difficult to assess success in implementing this law (NSC 2017).

\section{Gender Equality in the National Sustainable Development Strategy}

The NSDS (2013-2017) highlighted the importance of the family unit as the "foundation of the society" and national development, reinforcing the stereotype of women's role as unpaid carers. It also identified the need for progressive measures to improve economic opportunities for women "through the expansion of female employment into traditionally non-female occupations and expansion of women entrepreneurship support program," and supported the adoption of measures to reduce incidences of early marriage and to combat violence against women. The strategy also acknowledged the importance of addressing the narrow male stereotypes and destructive behaviors. A clear gap in the NSDS was the failure to set out an explicit principle in the promotion of women's political empowerment (NCSD 2013, p. 47).

15 Constitution of the Kyrgyz Republic 2010, Section 2, Article 16, p. 8.

16 See the Kyrgyz Republic Gender Equality Law. Para. 9. http://www.gender.cawater-info.net/publications/pdf/ gender_equality_kg.pdf. 


\section{National Gender Strategy and National Action Plans on Gender Equality}

The country's first long-term National Gender Strategy (NGS) on Achieving Gender Equality by 2020 was adopted in 2012 in compliance with CEDAW. The strategy's stated aim is "creat[ing] an institutional framework to ensure equal rights and opportunities of citizens, regardless of sex, age, social status, disability, gender identity and other grounds of discrimination, for the full realization of human potential of the Kyrgyz population."17 The NGS outlines the following five pivotal areas for improvement to pursue gender equality:

1. Strengthening institutional mechanisms and improving coordination in the implementation of gender policies at the national, regional, and sectoral levels;

2. Reducing the economic dependence and vulnerability of women as a result of the uneven distribution of reproductive and family burdens and an unbalanced labor market;

3. Improving the capacity of the education system to allow people to acquire the necessary life skills, leading to the furthering of equality and an improved quality of life;

4. Addressing gender discrimination and enabling access to justice for women; and

5. Creating gender parity in political participation and in all levels of decision-making (NSC 2017)

The NGS is elucidated through the 3-year National Action Plan on Gender Equality (NAPGE) for the periods 2012-2014, 2015-2017, and 2018-2020. These NAPGE highlight the following four core priorities: (i) women's economic empowerment, (ii) developing a system of functional education, (iii) eliminating gender discrimination and improving access to justice, and (iv) gender parity in decision-making and expanding women's political participation.

In 2013, a NAPGE for the implementation of Resolution 1325 of the UN Security Council was approved. ${ }^{18}$ It emphasized the importance of ensuring equal, comprehensive, and active participation of women in conflict prevention and resolution, peace building, and peacekeeping. It also promoted the development of gender-responsive civil society, the systematic generation of national gender statistics, the establishment of gender expertise mechanisms, and the introduction of special measures to support women in politics and governance spheres. The third NAPGE relating to Resolution 1325 was introduced in 2018.

A significant challenge to the implementation of the strategy and NAPGEs is the lack of dedicated resources. Although the concept of gender-responsive budgeting (GRB) was introduced a decade ago, accompanied by capacity development and pilot testing, it has yet to be mainstreamed in government policy, plans, programs, service delivery, and monitoring and evaluation.

17 See the Decision of the Government of the Kyrgyz Republic on the National Strategy on Gender Equality until 2020, and the National Action Plan on Gender Equality in the Kyrgyz Republic, No. 443, June 2012.

18 Resolution 1325 urges all actors to increase the participation of women and incorporate gender perspectives in all UN peace and security efforts. It also calls on all parties to conflict to take special measures to protect women and girls from gender-based violence, particularly rape and other forms of sexual abuse, in situations of armed conflict (https://www.un.org/womenwatch/osagi/wps/). 


\section{Introduction of $30 \%$ Gender Quota for Government Posts}

A $30 \%$ gender quota on elective posts was introduced in 2007. Subsequently, in 2017, amendments promoting gender equality were made to the Law on the Election of the President and Deputies of the Jogorku Kenesh. According to the changes, a female deputy who resigns early should be replaced by a woman, and a male deputy by a man. These changes were to ensure the maintenance of $30 \%$ women representation in the Parliament.

At the local level, the Law on the Election of Deputies of Local Municipal Councils (keneshes) was introduced in July 2011. The law stipulates that a maximum of $70 \%$ of candidates nominated in the electoral lists of political parties and voters' groups-for district and kenesh elections-may be of the same sex.

\section{E. Gender-Responsive Structures and Mechanisms}

\section{Gender Policy Department}

The Gender Policy Department of the Ministry of Labor and Social Development coordinates the implementation of gender policy. Considering its huge mandate, the department is understaffed with only five positions, four of which were filled as of November 2017. The department has a very small budget and has mostly depended on donor agencies' support for the implementation of the NAPGE. ${ }^{19}$

\section{National Council for Gender Development}

The National Council for Gender Development was established in May 2012 as an advisory body, chaired by the Deputy Prime Minister. It comprises ministers, deputy ministers, and heads of oblasts. In the 2015 CEDAW concluding observations, weaknesses were identified including (i) lack of political will to implement gender commitments, (ii) lack of coordination across the various elements of the national machinery, (iii) the limited capacity and authority of the responsible agencies to implement gender policy, (iv) continual turnover of personnel, and (v) no formal system of monitoring and evaluating the effectiveness of the national laws and programs.

\section{National Statistics Committee}

The NSC is the central statistical office for the country. It has considerable capacity-with 20 staff in the division of social statistics who are trained in generating sex-disaggregated data. ${ }^{20}$ It produces and publishes gender statistics, including the annual report-Women and Men in the Kyrgyz Republic. However, sex-disaggregated data are lacking for sectors that are generally perceived as gender-neutral, such as infrastructure improvement, transport and

19 Based on the interviews by the CGA consultant with the Ministry of Labor and Social Development, NGO representatives, and donor partners in November 2017.

20 Based on an interview by the CGA mission members with the NSC technical staff at the ADB Kyrgyz Republic Resident Mission, Bishkek in November 2017. 
energy, and climate change. The capacity of the NSC is limited by the fact that it does not operate independently and is reliant on the data feed from government agencies. In the process of expanding the sex-disaggregated database, another challenge is creating robust systems for collecting and conducting gender analysis of data to inform development planning. This difficulty is compounded by the lack of an accurate definition or understanding of "genderrelevant statistics." Government agencies must be encouraged to utilize the data when setting and prioritizing targets for their services.

\section{Gender Focal Points}

There is a network of gender focal points (GFPs) appointed within each ministry, government agency, and local and municipal authorities. However, the post is an add-on responsibility for the assigned persons and GFPs often have no direct responsibility for sector-specific policy making and development planning. There are often no standard terms of reference for GFPs and the role is often not included in the job descriptions against which they are evaluated. GFPs rarely receive methodological gender guidance and training and as a result have very limited capacity for gender analysis and planning. ${ }^{21}$

\section{F. Contribution of Civil Society to Gender Equality Policy and Practice}

Nongovernment organizations (NGOs) in the country play an important role in genderresponsive advocacy and program implementation. They participate actively in political life and provide a wide range of social services and assistance to vulnerable groups by protecting the rights and interests of citizens.

Women's rights and gender equality (WRGE) NGOs monitored gender equality and human rights since the submission of the first alternative report to CEDAW-by a team led by the Women's Support Center-in December 1999. WRGE NGOs helped in lobbying for the adoption of a new, comprehensive Law on Protection from Domestic Violence. A Council of NGOs was established in 2003 and included WRGE NGOs. The council's main objective is to monitor the compliance of government bodies and other agencies with the principles of equal rights and opportunities set out in the Kyrgyz Republic Constitution, the Gender Equality Law and NGS, the CEDAW, the BPFA, and other international commitments.

The Forum of Women's NGOs of Kyrgyzstan is an umbrella body established in 1994 that comprises 85 NGOs. The forum aims to consolidate and strengthen a women's movement toward gender equality and empowerment, with a focus on increasing women's participation in public life. Currently, it is an active player in regional networking and has consultative status with the UN Commission on the Status of Women.

In recent years, WRGE NGOs have accumulated technical expertise in the course of their advocacy and networking. They also have emerging expertise in the areas of agricultural production, appropriate technology, green energy, and microenterprise, among others.

${ }^{21}$ Footnote 20. 
Informants for this report observed that NGO networks are strong at the national level but are weak at the regional level. ${ }^{22}$

\section{G. Contribution of International Development Agencies to Gender Equality Policy and Practice}

Multilateral and bilateral aid agencies and international NGOs have supported genderfocused capacity building, policy reforms, and program implementation with government agencies and civil society organizations (CSOs). International aid agencies coordinate their activities through the Development Partners Coordination Council, which is a platform for information exchange and cooperation. ${ }^{23}$ Thematic groups, such as the Gender Thematic Group, consisting of GFPs from nine UN organizations and other bilateral agencies also hold regular meetings within the larger structure.

Donors have provided technical and fund assistance to the Ministry of Labor and Social Development in the drafting of the Gender Equality Law and other gender-responsive legislation and national action plans. They also supported the drafting of reports on international commitments such as on CEDAW, BPFA, and the SDGs-including support to the NSC for the systematic collection of gender-disaggregated data for monitoring the progress of the SDGs. Given the limited resources and capacities of the government, donors' support contributed to the passing of key gender legislation and the development of NAPGEs. Support included the training of gender advocates in government and NGOs. Women's NGO movement was also strengthened in the areas of gender, human rights, and political participation advocacy. In some cases, gender equality activists eventually went on to join state agencies. ${ }^{24}$

22 From reports of the CGA Consultation workshop held in Bishkek on 22 November 2017.

23 Information about the donors in the Development Partners Coordination Group is accessible at http://www. donors.kg/en.

${ }^{24}$ From the report of the CGA Mission workshop with donor partners held in Bishkek on 22 November 2017. 


\section{Crosscutting Gender Equality Issues}

\section{A. Gender Stereotypes and Sociocultural Norms}

The period following the Kyrgyz Republic's independence has seen a resurgence of prescriptive gender stereotypes, which are inextricably tied up with notions of national identity (Commercio 2014). The former Soviet Union era perception of an "egalitarian family," which revolved around a working mother was, to a large extent, replaced by conservative ideals of women remaining in the home to take care of her family (Ibraeva, Moldosheva, and Niyazova 2011) while men are expected to be the main breadwinners (Hoare 2009, p. 8).

Evidence indicates that these conservative ideas form an integral part of the national consciousness. In a 2017 World Bank study on gender norms in the Kyrgyz Republic, many respondents described a "good wife" as "one who sticks close to the home, takes care of the family and all household chores, respects and obeys her husband and in-laws, and who is patient, compliant, and obedient to the husband and his family" (Muldoone and Casabonne 2017). In a nationwide survey on perceptions of gender undertaken by UN Women and UNFPA in 2016,25 more than half of the respondents (51\% of women and $61 \%$ of men) stated that "a wife's career is less important than that of her husband," while $84 \%$ of female respondents and $85 \%$ of male respondents agreed with the statement: "A real woman is willing do housekeeping-it is a pleasure for her" (UN Women/UNFPA 2016). These ideals resonate with traditional Kyrgyz gender norms and have strong roots in Islamic beliefs, which have been revived in the post-independence period after 7 decades of formal atheism under the former Soviet Union rule (Muldoone and Casabonne 2017). Concurrently, there is pressure on Kyrgyz Republic men to be the family breadwinners and be strong, powerful heads of households. It appears that these perceptions are most prevalent among those living in rural areas (UN Women/UNFPA 2016).

Socioeconomic trends also contrived to increasingly reduce women's presence in the public sphere. Many professional roles in public services that were previously held by women disappeared after independence (Hoare 2009), while the possibility for women to seek new paid roles in the public and private sectors has been undermined by the difficulty of balancing home and work lives in the absence of subsidized childcare (Ibraeva, Moldosheva, and Niyazova 2011). This is further discussed in Section IIIb on women's economic empowerment.

In its 2015 Report on the Kyrgyz Republic, the CEDAW Committee drew attention to the following:

25 The study was conducted in 5,950 households in nine regions (including the cities of Bishkek and Osh) and included 16,145 women and men aged 15 years and over. 
"[T] $]$ he persistence of deep-rooted patriarchal attitudes and stereotypes concerning the roles and responsibilities of women and men in the family and society, which discriminate against women and perpetuate their subordination within the family and society. Those attitudes and stereotypes are reflected in women's educational and professional choices, their limited participation in political and public life, their unequal participation in the labor market and their unequal status in marriage and family relations. The Committee recalls that such stereotypes are root causes of violence against women and expresses its concern at the high prevalence of harmful practices that discriminate against women, such as child marriage and bride kidnapping, and that to date, the State party has not taken sustained measures to modify or eliminate discriminatory stereotypes, negative traditional attitudes and harmful practices." (CEDAW 2015, para. 15).

\section{B. Women's Economic Empowerment}

\section{Gender Inequality in the Labor Market}

The economic transition in the Kyrgyz Republic resulted in a huge loss of formal sector jobs, affecting both men and women. Of the total number of employed people in the country, only $25 \%$ are employed in the formal sector, while $76 \%$ of the economically active population are self-employed. ${ }^{26}$ Women were hit particularly hard during the transition. In 1991, 81.6\% of women were employed in the formal labor force, supported by public state-funded services and provisions that included day care centers, kindergartens, extended maternity leave, and access to basic health care. ${ }^{27}$ By 2007 , the employment rate for women was almost halved to 42.3\% (ADB 2005; Ibraeva, Moldosheva, and Niyazova 2011) and was even lower in some oblasts. ${ }^{28}$ This figure continued to drop. According to the UNDP GII, in 2018, 48.2\% of women participated in the formal labor market, compared to $75.7 \%$ of men. ${ }^{29}$ The latest NSC figures indicate that the employment gap is particularly significant for women aged 20-34, who are most likely to leave formal employment to care for young children and infants. ${ }^{30}$ In the 40-49 age group, the level of employment for men and women is similar, with many women returning to work when their children are older (UN Women/UNFPA 2016).

For those in the formal labor market, there is considerable gender segregation in the types of employment undertaken. According to NSC figures, the highest concentration of women is in the services sector, especially in health and social services where $83.6 \%$ of the labor force is female; education at $80.6 \%$; and hotels and restaurants at 58.4\% (Table 5) (NSC 2015a). By

26 The self-employed include farmers, migrant workers, entrepreneurs, and other informal sector workers (Scalise and Undeland 2016).

27 For example, the former state and collective farms, on which many women were formally employed, maintained a support infrastructure that included kindergartens, schools, hospitals, libraries, and other facilities, many of which were largely run by female staff (ADB 2005).

28 For example in Naryn oblast, it went down to 38.9\% (World Development Report 2011).

${ }^{29}$ See http://hdr.undp.org/en/countries/profiles/KGZ (accessed December 2018).

30 Figures for women's employment rate for 2016 indicate that only $33.4 \%$ of women aged 20-34 were employed compared to $50.1 \%$ of women aged $25-29$, and $54 \%$ of women aged $30-34$ (NSC 2017, p. 58). 
Table 5: Percentage of Women Employed in Various Sectors, 2012-2016

\begin{tabular}{|c|c|c|c|c|c|}
\hline Sector & 2012 & 2013 & 2014 & 2015 & 2016 \\
\hline Total & 40.9 & 39.8 & 40.8 & 40.4 & 39.6 \\
\hline Agriculture, forestry, and fishing & 40.2 & 41.4 & 44.5 & 44.0 & 41.1 \\
\hline Mining & 5.4 & 21.7 & 15.7 & 19.4 & 15.6 \\
\hline Manufacturing & 48.4 & 50.6 & 52.2 & 45.6 & 47.0 \\
\hline $\begin{array}{l}\text { Provision (supply) of electricity, gas, steam, } \\
\text { and air-conditioning supply }\end{array}$ & 14.3 & 11.7 & 13.9 & 11.6 & 9.5 \\
\hline $\begin{array}{l}\text { Water supply, cleaning, waste treatment, } \\
\text { and recycling }\end{array}$ & 23.2 & 27.8 & 39.7 & 44.7 & 37.6 \\
\hline Construction industry & 5.0 & 4.1 & 5.2 & 4.4 & 3.5 \\
\hline $\begin{array}{l}\text { Wholesale and retail trade, repair of cars } \\
\text { and motorcycles }\end{array}$ & 47.4 & 42.8 & 38.3 & 40.3 & 38.6 \\
\hline Transport and storage of goods & 8.0 & 4.7 & 6.0 & 5.2 & 6.7 \\
\hline Hotels and restaurants & 70.0 & 65.8 & 64.1 & 59.4 & 58.4 \\
\hline Information and communication & 43.9 & 24.6 & 32.3 & 28.2 & 29.0 \\
\hline Financial intermediation and insurance & 39.0 & 44.3 & 38.5 & 39.2 & 41.4 \\
\hline Real estate operations & 51.8 & 83.7 & 89.2 & 93.2 & 77.5 \\
\hline Professional, scientific, and technical activities & 32.1 & 37.2 & 39.8 & 36.0 & 42.2 \\
\hline Administrative and auxiliary activities & 34.4 & 15.8 & 26.4 & 31.8 & 30.4 \\
\hline Public administration & 37.1 & 32.4 & 34.9 & 35.4 & 39.0 \\
\hline Education & 76.6 & 78.3 & 78.6 & 78.7 & 80.6 \\
\hline Health and social services & 85.9 & 85.1 & 83.3 & 84.1 & 83.6 \\
\hline Art, entertainment, and recreation & 40.7 & 47.1 & 49.5 & 49.0 & 53.1 \\
\hline Other service activities & 48.7 & 39.1 & 45.0 & 51.1 & 50.8 \\
\hline Private household activities & 51.7 & 21.3 & 24.7 & 33.7 & 46.6 \\
\hline $\begin{array}{l}\text { Activity of extraterritorial organizations } \\
\text { and bodies }\end{array}$ & 20.0 & & & & 26.0 \\
\hline
\end{tabular}

and bodies

Source: NSC (2017). p. 64.

contrast, highly paid technical sectors are dominated by men where they represent $84.4 \%$ of employees in the mining industry; $90.5 \%$ in the production of gas, electricity, and water; $89.3 \%$ in transport and communications; and $96.5 \%$ in the building industry.

This predominance of women in often lower-paid sectors is reflected in the considerable gender wage differential, with women receiving an average $74.3 \%$ of men's earnings in 2012 and $75.3 \%$ in 2016 (NSC 2017, p. 98). The tendency for girls to study nontechnical subjects at school and in higher education limits their employment potential to these less well-paid sectors (Law and Development Partnership and EBRD 2015). Other contributing factors include the poor representation of women in senior positions, even in sectors where they dominate-such as education, health care, catering, and social services; and a tacit bias among some employers due to the economic costs of paying for maternity leave and offering flexible arrangements for women with young families (Hoare 2009). Another factor restricting women's employment in certain areas may be the existence of a list of 400 occupations that 


\section{Figure 2: Women and Men Employed in the Informal Sector, 2003-2012 ('000)}

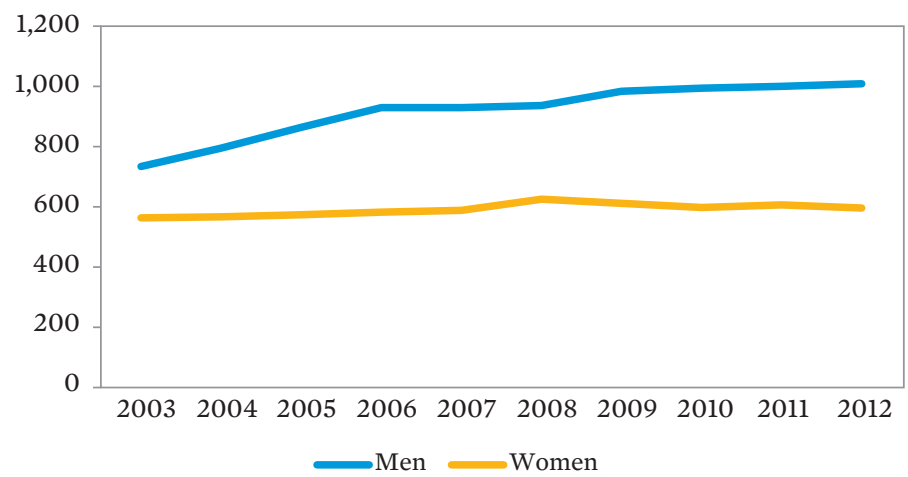

Source: Sayakbaev and Mokrousova (2014). pp. 47-48.

are legally forbidden for women to undertake, ostensibly for reasons of health and safety, but in reality many of the original perceived constraints no longer exist due to advances in technology and working practices (Law and Development Partnership and EBRD 2015). ${ }^{31}$

The reduction of jobs in the formal labor market during the transition period and following the structural crisis of the country's economy in 2006-2007 led to an influx of people entering the informal economy. Many informal workers are male, but the informal sector also accounts for a high percentage of female. Informal labor includes activities where women undertake street and "shuttle" trading, ${ }^{32}$ home-workers, paid care givers, street and market vendors and agriculture. In addition, a growing percentage of women manage micro and small enterprises (Figure 2) (Ibraeva, Moldosheva, and Niyazova 2011).

\section{Unemployment}

Aggregate unemployment figures remain high in the country, but women comprise the majority of the unemployed. In 2016, the unemployment rate was $8.7 \%$ for women, compared with $6.2 \%$ for men (ADB 2014a). The loss of state-run posts in education, health care, local administration, and other vital areas where many women were previously employed had a particularly stark impact, and the resulting void has not been filled with new economic opportunities. The lack of subsidized childcare and public services, such as kindergartens, also limited the employment choices for many women with young children or with other caring responsibilities (TRACECA 2013).

31 The list contains industries, occupations, and positions with harmful and/or dangerous working conditions that are prohibited for women's employment. Extreme working conditions mean conditions under which an employee is exposed to a high risk of diseases and poisoning, injury, and threats to life and health (for example, work where explosive and flammable materials are used, and/or work underground, underwater, or in closed tanks). The full list is provided in a government decree available at: http://cbd.minjust.gov.kg/act/view/ru$\mathrm{ru} / 7182$ ? $\mathrm{cl}=\mathrm{ru}-\mathrm{ru} \# 1$.

32 Petty trading involves the sale of goods from other neighboring countries. 
Table 6: Unemployment among Women and Men, 2012-2016 ('000)

$\begin{array}{lrrrrr} & 2012 & 2013 & 2014 & 2015 & 2016 \\ \text { Female } & 9.5 & 9.7 & 9.5 & 9.0 & 8.7 \\ \text { Male } & 7.7 & 7.4 & 7.0 & 6.5 & 6.2 \\ \text { Total } & 17.2 & 17.1 & 16.5 & 15.5 & 14.9\end{array}$

Source: NSC (2017). p. 69 (accessed October 2018).

\section{Entrepreneurship}

The available evidence indicates very little take-up of micro, small, and medium-sized enterprises (MSMEs) by women. In 2013, women constituted $28 \%$ of the managers in small firms, $31 \%$ of the managers of medium-sized firms, while $16.5 \%$ of agricultural enterprises were headed by women (ADB 2014d). The UN Women/UNDP national survey in 2016 found that only $4 \%$ of female respondents were engaged in entrepreneurship, which is just half the number of men (8\%) (UN Women/UNFPA 2016).

The lack of start-up capital is a barrier to the entry of both men and women into entrepreneurship, but women also face gender-specific barriers. A key challenge is the male dominance of the finance sector: women attempting to negotiate with male loan officers have reported encountering gender biases, including being told to bring their husbands if they wish to apply for a loan (ADB 2005; Ibraeva, Moldosheva, and Niyazova 2011). There are efforts to improve women's access to credit, particularly through microfinance programs. In 2014, 63.4\% of microloan recipients were female in all regions of the country. However, borrowing patterns indicate that many women tend to use microfinance institutions (MFIs), which offer less credit for shorter terms, rather than borrowing from commercial banks. In addition, women are often restricted to micro and small businesses, taking up smaller loans than men. A 2016 study on MFIs found that $86 \%$ of female clients borrow less than $\$ 1,100$ and only $2 \%$ borrow over $\$ 2,000$. Women are also more likely than men to borrow as a group (FAO 2016) and are often not equipped with the information and knowledge needed to set up MSMEs (ADB 2005).

Women's entrepreneurship is also limited by access to technology and equipment. According to an ADB study considering barriers and opportunities for female entrepreneurs in Azerbaijan, Kazakhstan, the Kyrgyz Republic, and Uzbekistan (ADB 2014b), the Kyrgyz Republic has the second highest access to mobile phones in Central Asia but ownership of a household computer and access to the internet remain very low. Although one-third of respondents to the study owned an internet-capable mobile phone, only a little over $12 \%$ used their phone to access the internet. When asked about Information and Communication Technology (ICT) support needs, almost half of the women entrepreneurs listed ICT education and training as their top priority. They requested training on how to promote products or services via the internet, how to use the internet for business, and how to use the internet on their mobile phones. Nearly half of the female entrepreneurs participating in the regional study wanted to learn how to use mobile phones for their business needs (ADB 2014b). 


\section{Land Rights}

The concept of private land ownership was introduced in the 1990s in the Kyrgyz Republic. State and collective farms were dissolved and redistributed to all members of farm workers' families, and to medical workers and teachers living in the locality. Over 2.6 million people-of which over $50 \%$ were women and girls-received land shares. However, many women did not benefit from this strategy (FAO 2016), despite the fact that Kyrgyz laws provide women and men equal ownership rights to property regardless of their marital status. While there are no formal or legal barriers to women's property ownership, under customary laws and traditions, men are far more likely to inherit and own land and property. As a result, most women are "asset poor," without ownership rights or property. The Kyrgyz Republic 2011 Law-"On management of agricultural lands"-presents a further challenge for women who marry and leave the family home to live with their husbands. Land shares cannot be subdivided, donated, or exchanged within families, leaving brides with the option to sell their legal share to the family. Yet, in practice, few women claim this monetary right because "If a daughter or a daughter-in-law dares to assert their right to property in court, the community is likely to perceive this as disrespect towards tradition and a violation of the natural way of life," (Ibraeva, Moldosheva, and Niyazova 2011, p. 33) so the land is often inherited by male siblings (FAO 2016). Women who divorce have no rights to inherit land from their families (FAO 2016).

On house ownership, a 2015 study found that among rural women aged 15-49, 43.7\% do not own housing at all and less than $5 \%$ have sole ownership of houses. Among rural men aged $15-49,31.3 \%$ do not own housing and $32.2 \%$ have sole ownership rights (Djanaeva 2015). According to the UN Women/UNDP survey, $62 \%$ of houses are registered in men's name, and only $29 \%$ in women's name. All other assets are mainly registered in men's names-including $61 \%$ of commercial real estate, $80 \%$ of land, $90 \%$ of passenger vehicles, and $93 \%$ of agricultural transport. Women's right to sell property is also limited by the need for the consent of both spouses (UN Women/UNFPA 2016).

Without full ownership, women's ability to use property-such as selling, renting it out, or offering it as collateral to secure loans-is compromised and this often puts them at risk of extreme poverty in cases of divorce, abandonment, or other situations where they are not supported by a male property owner (Djanaeva 2015).

\section{Gender Dimensions of Human Development}

\section{Education}

There is a high level of enrollment in education in the Kyrgyz Republic, and near gender parity at the primary level. This changes at the secondary level where the number of girls graduating significantly outnumbers that of boys. During school year 2013-2014, enrollment in upper secondary education was 50.2\% for boys and 56.7\% for girls (ADB 2014a, p. 100). Nonattendance in school and dropping out vary considerably between rural and urban areas. In rural secondary schools (grades 5-11), boys are much more likely than girls to be out of school, and more likely to stop attending as they grow older (FAO 2016).

The cost of education is likely to be a contributing factor to this gender imbalance. During the former Soviet Union period, education was state-funded and free to all students, and 
education up to secondary level was compulsory. Following the country's independence, a government policy was introduced that considerably reduced state funding and required citizens to participate in the financing of their children's education (up to $50 \%$ of school running costs) (Scalise and Undeland 2016).

There are indications that this financial burden prevents some poorer families in rural areas from enrolling their children in secondary school (UNICEF 2008). Boys are most likely to be pulled out of school by their parents or to miss classes so they can help support the family income (Scalise and Undeland 2016), but research shows that girls also miss or drop out of school at an early age. ${ }^{33}$ In some cases, poorer families may be choosing not to educate their daughters at upper secondary and tertiary levels because after marriage only their husbands' family will benefit. Poverty may also lead parents to agree to the early marriage of their daughters because of the potential financial gain from the bride price. In some cases, parents may withdraw their daughters from school to protect them from potential kidnapping or premarital sexual activity (Commercio 2014).

At the tertiary level, there is also a gender imbalance in favor of women with enrollment of $46 \%$ female and 37\% male students (World Bank 2015). However, gender stereotypes affect enrollment in technical and vocational education and training (TVET) institutions. ${ }^{34}$ For example, during the 2014-2015 academic year, girls only constituted only $29.4 \%$ of students enrolling in TVET (FAO 2016). This may be partly due to a perception that TVET is less prestigious than university education in the Kyrgyz Republic. ${ }^{35}$

The choice of subjects is also heavily affected by normative gender perceptions, with many female students opting for non-STEM (science, technology, engineering and mathematics) subjects, including education, health, and services (NSC 2017, p.53). Of the students enrolled in power industry courses in 2016-2017, 83.1\% were male and only $16.9 \%$ were female. Male students accounted for $100 \%$ of those enrolled in metrology, standardization, and quality control; $99.5 \%$ of mechanical engineering and material processing students; $98.3 \%$ of electrical engineering students; and $94.8 \%$ of those studying in the field of energy (NSC 2017).Women and girls continue to choose traditionally female-dominated fields as education, garment making, or food processing. Only $21.1 \%$ of students enrolled in architecture were women. Gender stereotypes held by students, their parents, and TVET institutions themselves about appropriate jobs for women and men help to reinforce the gendered nature of subject choices (ADB 2014e).

NSC statistics and the GGGI indicate the continued unemployment of the increasing numbers of educated women in the Kyrgyz Republic. While much of this imbalance may be explained by gender norms in women's care-giving duties, the lack of subsidized childcare, the hidden gender discrimination by employers, and the skills differentials in the degrees that women and men seek out in education are likely to be an additional factor.

The 2015 CEDAW Concluding Observations recommended "prioritizing the elimination of negative stereotypes and structural barriers to the enrolment of girls in nontraditional fields of education at the secondary and tertiary levels and to provide career counseling for girls

33 According to a research carried out in several southern provinces, boys more often miss school due to paid work, while girls tend to be out of school because they are performing unpaid household chores, sometimes for their husbands' families, in the case of early marriage (UNICEF 2008).

34 The government invested in TVET at tertiary level although the more affordable technical education is generally less prized than university education.

35 In a 2014 study, meetings with schoolchildren aged 14-16 indicated that TVET still has a negative image and that university education is considered more prestigious (ADB 2014e). 
on nontraditional career paths such as science and technology; intensify efforts in reviewing school textbooks and curricula to eliminate gender stereotypes; and to provide updated disaggregated data on the educational choices of women and girls" (CEDAW 2015).

Improving the standard of education is also a priority for the government and donors. The dramatic fall in state funding for education following the transition resulted in poor quality, outdated educational provision; a lack of textbooks and other teaching aids (Ibraeva, Moldosheva, and Niyazova 2011); poor infrastructure; and a lack of basic services, such as electricity, water, and sanitation (Scalise and Undeland 2016).

\section{Health}

Maternal and infant mortality rates remain high, especially in rural areas, owing to inadequate prenatal care, the growth of external and internal migration, the low level of awareness and level of education among pregnant women and mothers about family planning and pregnancy, and the low quality of nutrition for women. The CEDAW Committee identified the need for improved programs and services to ensure the poor women's access to maternal health care (CEDAW 2015, para.31).

Table 7: Maternal Mortality Ratios for the Kyrgyz Republic, 2012-2016

\begin{tabular}{|lcc|}
\hline Year & No. & Per 100,000 Children Born Alive \\
\hline 2012 & 76 & 49.1 \\
\hline 2013 & 56 & 36.0 \\
2014 & 81 & 50.1 \\
2015 & 63 & 38.5 \\
\hline 2016 & 48 & 30.3 \\
\hline
\end{tabular}

Source: NSC of the Kyrgyz Republic. Statistics from 2018 (accessed October 2018).

\section{Violence against Women}

\section{Harmful Practices}

Concerns are being raised by national and international agencies over the reemergence of deeply patriarchal customary norms that include bride kidnapping, forced and early marriage, and polygamy (Hoare 2009). There has been a steep increase in incidences of bride kidnapping (ala kachuu) - the act of abducting a woman for marriage-in the 2 decades after independence despite this practice being officially made illegal in 1994, with further amendments to the law in 2013. ${ }^{36}$ The CEDAW Committee has labeled bride kidnapping a "harmful practice," which discriminates against women (UN Women/UNFPA 2016, p. 54) (Box 1).

The legal minimum age of marriage in the Kyrgyz Republic Family Code (Article 14) is 18 but evidence indicates that a high number of girls are below this age when they got married. There

36 Articles 154 and 155 of the Criminal Code criminalize the act of bride kidnapping. In 2013, President Almazbek Atambayev signed a new law that increased the penalty for bride kidnapping to 7 years' imprisonment and 10 years if the bride is a minor (Muldoone and Casabonne 2017). 


\section{Box 1: Bride Kidnapping in the Kyrgyz Republic}

Ala kachuu, an ancient Kyrgyz practice outlawed during the former Soviet Union period, involves a young man and his friends taking a young woman by force or deception into a car and driving her to the home of his parents or relatives. The girls are usually raped immediately after the kidnap, which makes it impossible or too shameful for the girl's family to refuse marriage because the loss of virginity reduces any future opportunities for marriage. A member of the groom's family then presents the girl with a marriage scarf (jooluk). By placing the scarf over her hair, the girl publicly accepts the offer of marriage. She is then expected to write a letter to her family announcing that she consents to the marriage. Faced with enormous pressure and the virtual impossibility of returning to her own family due to the shame associated with kidnapping, the girls in this situation usually consent, even when the marriage is against their wishes. The groom's family brings the letter, along with the bride price in the form of sheep or other gifts, to the girl's family. An Islamic clergyman (moldo) is then invited to perform an Islamic ceremony (nikah) (Commercio 2014).

Prior to the former Soviet Union period, bride kidnapping may have been practiced mainly as a form of consensual elopement, allowing the bride and groom to evade their families' opposition to their marriage or to keep marriage costs down. ${ }^{a}$ This may still be true in some cases but research indicates that the practice is increasingly characterized by its nonconsensual nature, with girls expected to submit to the practice as a sign of their willingness to build the new Kyrgyz nation and boys encouraged to undertake the kidnapping as a sign of their ultra-masculinity (Commercio 2014).

Statistical evidence conducted in villages in 1999, 2001, and 2004 indicated that the number of ethnic Kyrgyz women married against their will as a result of bride kidnapping increased from 33\% in 1999 to $45 \%$ in 2004 (Ibraeva, Moldosheva, and Niyazova 2011). Although there are no recent official figures, in 2012, it was estimated that up to 12,000 women were being kidnapped for marriage each year (Equal Rights 2016). Qualitative evidence from the World Bank suggests that the phenomenon may now be declining but remains prevalent in the country. A 2016 study conducted by United Nations Population Fund (UNFPA) on 5,000 households found that one-fifth of marriages in the country was the result of kidnapping, both consensual and nonconsensual. The study found that the majority of abducted women were from the poorest households and had little or no education (Muldoone and Casabonne 2017).

Because of the illegal nature of bride kidnapping, these marriages are often not registered, leaving the women without formal rights to own or inherit marital property, to seek divorce, or claim child support enjoyed by registered spouses (Muldoone and Casabonne 2017).

a The bride price is usually around a third lower for abducted brides (Muldoone and Casabonne 2017). Sources: Ibraeva, Moldosheva, and Niyazova (2011); M. Commercio (2014); and R. Muldoone and U. Casabonne (2017).

are no official figures because early marriages are usually not registered, but in 2014, $12.7 \%$ of female respondents aged 20-49 participating in a national statistical survey said they had married, or entered into an unregistered marriage, below the age of 18 (NSC and; UNICEF 2015). CSOs contributing to a joint submission to the Universal Periodic Review in 2014 estimated that approximately $12.2 \%$ of women enter into underage marriages, with this figure rising to $14.2 \%$ in rural areas (NGOs on Child Rights 2014. para. 3). The growing trend can be tracked through the sharp increase in births among minors aged 15-17. The incidence of births in this age group increased from 4.4 children per 1,000 in 2006 to 7.4 per 1,000 in 2014. The 
birth rate is also increasing for young women over the legal age of marriage: in 2008, there were 62 registered births per 1,000 women aged 18-19 compared to 84 (NSC 2017) in 2016. ${ }^{37}$

Bride kidnapping is also associated with underage marriage: according to a 2011 World Development Report, "Typically, the average age of men and women entering into this kind of marriage is getting younger, sometimes grooms have barely crossed the threshold of sexual maturity, and brides do not even finish secondary school" (Ibraeva, Moldosheva, and Niyazova 2011).

Bride kidnapping is criminalized by the Criminal Code, which also prohibits forcing an adult woman into marriage, preventing an adult woman from marrying and abducting a woman against her will for the purpose of marriage. However, there is weak enforcement of the Criminal Code. In 2009, the UN Special Rapporteur for Violence against Women drew attention to "the light penalties imposed for this crime and the fact that there is little or no social stigma attached to abduction among many sections of the population" (Equal Rights Trust 2016). In 2016, the country adopted Act 179 that amended the Family Code and Criminal Code of the Kyrgyz Republic to prohibit early marriage of minors. Ministries and departments draft action plans to monitor its implementation.

\section{Domestic Violence}

Domestic violence is widespread and common in the Kyrgyz Republic, but much of the evidence is informal or based on estimates (Table 8) (Childress 2017; Equal Rights Trust 2016; FAO 2016). The most recent comprehensive data on the issue comes from a government Demographic and Health Survey conducted in 2012 indicating that $23 \%$ of all women aged 15-49 have experienced physical violence at least once in their life. This rises to $28 \%$ for married or formerly married women, with $4 \%$ reporting exposure to sexual violence and $14 \%$ to emotional abuse at the hands of their current or former partner. ${ }^{38}$ Of those experiencing abuse, only 39\% sought assistance. Evidence from women's NGOs in the Kyrgyz Republic suggests that the actual numbers are far higher. The majority of cases go unreported for reasons that include fear of retaliation by the perpetrator, concern over social stigma, and a lack of available services, such as shelters and financial assistance (Moldosheva 2008).

\section{Table 8: Official Figures on Domestic Violence in the Kyrgyz Republic,} 2014-2017

\begin{tabular}{|c|c|c|c|c|}
\hline & 2014 & 2015 & 2016 & 2017 \\
\hline Recorded cases of domestic violence, by type: & 3,126 & 3,524 & 7,053 & 7,333 \\
\hline (i) physical & 2,408 & 2,675 & 4,846 & 4,827 \\
\hline (ii) psychological & 712 & 840 & 2,204 & 2,502 \\
\hline (iii) sexual & 6 & 9 & 3 & 4 \\
\hline Number of issued temporary protection orders & 2,619 & 3,358 & 6,966 & 7,323 \\
\hline $\begin{array}{l}\text { Number of criminal cases due to domestic violence, } \\
\text { and sent to court }\end{array}$ & 243 & 238 & 199 & 218 \\
\hline Number of persons brought for administrative action & 1,624 & 2,381 & 4,901 & 4,946 \\
\hline
\end{tabular}

Sources: S. Childress (2017); NSC of the Kyrgyz Republic (2017, 2018).

37 See NSC of the Kyrgyz Republic (2016) cited in Muldoone and Casabonne (2017).

38 NSC of the Kyrgyz Republic, Ministry of Health (Kyrgyz Republic), and ICF International (2013), cited in Childress (2017). 
Cultural norms-internalized through proverbs and phrases-reinforce the perception that violence is a natural part of marriage for many women, which should be endured (Childress 2017; Equal Rights Trust 2016; FAO 2016). According to Kyrgyz tradition, after marriage, a woman leaves her parental home to live with her husband and, often, his extended family. She becomes "almost the property of the new family" and is strongly discouraged from seeking support from her parents. In their new roles as daughters-in-law and wives, women often find themselves in situations of disempowerment and isolation, unable to speak up against abuse in their new families (Childress 2017; Equal Rights Trust 2016; FAO 2016) and unwilling to bring shame to their birth families and communities. The sense of powerlessness is even more severe for those who have been coerced into marriage and/or are below the age of 18 (Muldoone and Casabonne 2017). The common perception is that women are responsible for inciting the violence and are to blame if they are unable to prevent or stop it. ${ }^{39}$ One survivor of domestic violence who participated in a qualitative research study said:

"We just kept going like that. After he beat me, I would say I would not live with him anymore and go to my parents' house, but they wouldn't listen to me and [would] always send me back.... I had no support either from my Dad or my Mom.... At the end, even when I was beaten up till my skull was broken open, I didn't go [to my parents' house]. There was no point for me, as I understood, the wife is compared to a "neck," which can turn the husband's head in the right direction, and if the woman is not able to manage the situation and avoid being hurt, she is seen as failing to fulfill her duty as a caretaker and the peacemaker in the family" (Childress 2017, p. 8).

Deep-rooted concerns about the shame and stigma associated with domestic violence prevents many women from going to the police, even if they are aware of their right to do so, and of the legislation making domestic violence illegal (Childress 2017; Equal Rights Trust 2016; FAO 2016).

\section{Responses to Domestic Violence}

This problem has received attention at both state and nongovernment levels. In 2005, systems for collecting sex-disaggregated data on victims and perpetrators of violence were introduced into law enforcement agencies, which are now required to record the types of violence perpetrated. Data are now systematically collected on the (i) number of victims, (ii) demographic profiles of individuals approaching crisis centers for assistance, and (iii) the legal responses such as the number of protective orders issued and the number of criminal cases filed. This process has helped inform the development of targeted state policy and legislation (FAO 2016).

NGOs have played a key role in raising general awareness on domestic violence and other forms of gender-based violence. They have also helped in lobbying the government to introduce and pass protective legislative measures. Women NGOs have also provided safe houses, shelters, and counseling services for domestic violence survivors (Scalise and Undeland 2016).

39 Women may be seen to warrant the abuse by their in-laws and husband because they are not working hard enough or have failed to give birth to sons (Childress 2017.) According to a national study, one in every two women accepts that husbands are usually justified in beating their wives, and that wives often cause them to do so by arguing with them (Joshi and Childress 2017). 
The law "On Social and Legal Protection from Domestic Violence" was adopted in 2003. The law sets out the responsibilities of social services in supporting people escaping domestic violence and provides for "temporary restraining orders" and "protective court orders," which prohibit perpetrators from contacting the victim. The law also calls for least one shelter space to be provided per 10,000 people. However, the law's implementation has been poor, with few cases being brought to court and minimal state provision of safe houses and shelters. One organization reporting in 2016 noted that in Bishkek, there was only one governmentfunded shelter that receives government funding with only 15 available places in a city of almost 1 million (Equal Rights Trust 2016). National and local gender equality and women's rights (-NGOs have taken the initiative to establish safe houses and counseling services for victims. The Association of Crisis Centers in the Kyrgyz Republic was established in 2001. In 2018, the association included 12 crisis centers where domestic violence survivors could seek legal advice, medical assistance, and employment advice. Women who received support from crisis centers numbered 6,113 in 2017 and 5,520 in 2018. ${ }^{40}$ There is a clear need for both donor support and greater commitment from the government to ensure the urgent building of more operational shelters. Lessons can be drawn from ADB Mongolia, which has dramatically increased its funding to prevent and address domestic violence (Box 2).

\section{Box 2: ADB Support for Addressing and Preventing Domestic Violence in Mongolia}

The Asian Development Bank and the Government of Mongolia signed a \$3 million grant agreement in December 2018 to support the prevention and response to domestic violence. The grant, funded by the Japan Fund for Poverty Reduction, is ADB's first stand-alone project addressing domestic violence. It will fund the establishment of shelters in three provinces and two districts. It will also ensure accessibility to protection services of people with disabilities who are at high risk of genderbased violence. The project will also focus on prevention-such as the launching of behavior change communication activities. Under the project, men and adolescent boys and girls in project sites will be engaged to increase their understanding of domestic violence and to promote positive role model behavior.

Source: ADB. 2018. ADB Signs its First Project on Domestic Violence Response and Prevention in Mongolia. https://www.adb.org/news/adb-signs-its-first-project-domestic-violence-response-and-preventionmongolia.

In April 2017, the Kyrgyz Republic introduced a new law on "Safeguarding and Protection Against Domestic Violence," which replaced the earlier 2003 Law (Human Rights Watch 2017; UN Women 2017). Under the old law, only those subjected to domestic violence directly could report it to the police, yet they are often unable to do so for fear of reprisals from the perpetrators or family members. The new law allows anyone who is aware of domestic violence occurring to report it. In addition to recognizing physical, sexual, and psychological violence, the new law also recognizes economic violence, such as restricting access to and use of financial resources, property, or other assets. The new law focuses on protecting the victims by defining clear roles and responsibilities of the state and local self-governing bodies, improving mandatory protective orders for survivors, and ensuring access to shelters, medical

40 National Statistics Committee (NSC). 2018. Number of Public Appeals to Crisis Centers, Aksakal Courts and Other Specialized Agencies. Bishkek. http://stat.kg/en/statistics/gendernaya-statistika/. 
and other key services, and legal aid. It aims to prevent perpetrators from doing it again through a behavioral correction program. Achieving effective coordination and appropriate responses to such cases is also a critical component of the new law, with provisions for ensuring that relevant actors-including police, judicial officials, health care providers, social workers, and local authorities-receive appropriate training on domestic violence.

\section{Women's Unpaid Care Work and Time Poverty}

The NGS 2012-2020 acknowledges that the uneven distribution of reproductive and family responsibilities contributes significantly to women's economic dependence and vulnerability. A time budgeting study conducted in 2015 indicated that many women and men generally conform to traditional gender roles, with women taking greater responsibility for unpaid domestic work and men spending more time in paid employment. The study found that, on average, women and adolescent girls spend 4 hours and 30 minutes per day on household chores, which accounts for $18.8 \%$ of their time every day, whereas men and adolescent boys spend only $6.5 \%$ of their time on these activities -1 hour and 20 minutes. Of women's time, $88 \%$ is taken up with tasks such as cooking, cleaning, and laundering, while men often spend more time purchasing food and undertaking home repairs. The study indicated that women spend double the amount of time per day on childcare compared with men. ${ }^{41}$

It also found that women living in rural areas spend around 303 minutes per day on housework, 1.5 times more than women in urban areas (NSC 2015c; UNDP 2016d). The unequal gender division of labor, coupled with the deterioration of public support services, has seriously constrained employment opportunities and-in some cases-access to higher education for women of childbearing age. A World Bank report found that women aged 25-34 who are at the peak of childbearing and child-rearing had the most limited access to economic opportunities (World Bank 2015). One of the causes of low involvement of women in the labor market is the decline of access to free or subsidized childcare and poor provision of early childhood education (Hoare 2009). At the time of writing in 2018, only $18 \%$ of children under the age of 7 received preschool education. Provision is particularly poor in rural areas. According to a multiple indicator study from the NSC and UNICEF for 2014, only $16.0 \%$ of children aged 3-5 attended preschools compared to $40.5 \%$ in urban areas (NSC and UNICEF 2015).

The increasing trend of households headed by females due to the high level of male labor migration has also intensified women's time poverty. Reports from some women's NGOs indicate that many of them face problems related to housing, living conditions, and limited access to natural resources such as lack of heating, lighting, fuel, safe sanitation, and poor quality of drinking water that leads to malnutrition and diseases. This increases the time and work burden of rural women and children who are responsible for collecting water, and negatively reduces women's potential opportunities for income-generating activities (Djanaeva 2015).

41 See NSC (2015c), Table 1.A. p. 11. The survey gathered information on males and females aged 12 and over (FAO 2016, p. 30). 


\section{E. Women's Resistance to External Shocks}

\section{Gender Impacts of Climate Change}

Climate change severely affects the poorest and most vulnerable populations, particularly women and girls because of the increased time burden, reduced economic opportunities, and health implications associated with increasingly scarce resources and the disproportionate exposure to risk from climate-induced phenomena, such as floods and hurricanes-compared with men (Brody et al. 2008; Skinner 2011).

In the Kyrgyz Republic, climate change and environmental degradation are leading to deteriorating soil quality, water scarcity, and other phenomena such as floods, mudflows, and earthquakes-which all have a disproportionate effect on women and girls. For example, women and girls are often the most affected by water shortages as they need access to water for tasks such as cooking, cleaning, and bathing children. In times of scarcity, they may restrict their own personal use, which can lead to psychological and physical discomfort during menstruation (FAO 2016). A UNDP study points out the gender impacts of decreased availability and quality of drinking water associated with climate change. It notes that an average of $6.5 \%$ of households in the country spend more than 30 minutes in the collection of water, and that in $49.3 \%$ of households, water is collected by women and girls under the age of 15 (UNEP 2017). Evidence also indicates that male farmers have better access to water for irrigation during times of drought (FAO 2016).

Given the immediate effects of climate change on women and girls and the differential gender impacts, the involvement of women on an equal basis with men in all climate and environment-related decision-making processes is critical to ensure a gender-responsive adaptation to climate change and resilience in the face of climate-induced disasters (UNEP 2016). For example, water and sanitation services are often more effective and more sustainable if women have an active role in designing, planning, and operating facilities and programs. Women can also play an important role in educating their families and the community about good hygiene. Yet, a UNDP study in 2013 found very low female representation in water users associations (WUAs), which make significant decisions about water distribution and use. According to the study, out of 4,175 people working in the WUAs, only $18 \%$ were women. In a sample of 436 WUAs throughout the country, only six had female directors, there were only two female chairpersons and nine vice chairpersons of WUA councils (UNDP 2013). This gender imbalance is even more prevalent at higher levels of decision-making. In the State Agency on Environment Protection and Forestry, the National Designated Authority for Climate Change issues, women constitute $32.6 \%$ of all employees but the majority hold administrative positions. Only 3 of 9 heads of divisions are female. ${ }^{42}$

42 State Agency on Environment Protection and Forestry. http://www.ecology.gov.kg/. 


\section{F. Leadership and Decision-Making}

\section{Political Representation}

Women's political representation remains relatively low in the Kyrgyz Republic. There was an initial sharp decline in the number of female political representatives at state and local levels following independence due to the dissolution of the former Soviet Union quota system, which guaranteed women 33\% of seats in the Council of People's Deputies. After the 2002 elections, women accounted for only 6.7\% of Deputies in the Supreme Council (Jogorku Kenesh) of the Kyrgyz Republic Parliament (Scalise and Undeland 2016). By 2005, the Kyrgyz Parliament was solely composed of men. At the executive government level, a similar downward trend is noted in the level of women's representation in high-level positions. The adoption of mandatory quotas in the amended Election Code in 2007 and 2011 helped improve women's representation in elected office at national and local levels..$^{43}$ By 2016, women constituted $15.8 \%$ of parliamentarians in the Jogorku Kenesh (NSC 2017, p. 85) and in 2018, they comprised $16 \%{ }^{44}$ Despite a considerable increase in the number of women in office, the $30 \%$ threshold identified by the BFPA as critical to women's effective voice in decision-making has not been reached. Nonetheless, women's greater representation in the Parliament has made a positive impact, notably increasing the focus on social issues and gender equality. Female members of the Parliament introduced amendments and laws on issues in education and family law.

While the country has mechanisms for boosting women's participation at the national level, there are fewer such mechanisms at the local level. There has been "a steady and significant decrease in the number of women elected to local councils through the majority system: $19 \%$ in $2004,17 \%$ in $2008,13 \%$ in 2012, and $10 \%$ in $2016 . "{ }^{45}$ At the local level, the percentage of women among the heads of ail okmotu (executive bodies in village settlements) has not reached more than $5 \%$ of the approximately 500 positions (NSC 2017, p. 87). Government set a $30 \%$ quota for elected women deputies in local councils in 2019 under the amended Law on the Election of Deputies of Local Keneshes.

The CEDAW Committee observed that the low participation of women in political and public life, particularly in decision-making positions and in municipal governance bodies, is rooted in persistent patriarchal attitudes. It points to factors such as insufficient capacity building and campaign funding for potential women candidates, which impede women's equal participation in political life (CEDAW 2015, para. 23). The UN Women/UNFPA nationwide survey found that the key obstacle to women's political participation is the lack of support from their spouse and family, with $50 \%$ of both female and male respondents citing this reason (UN Women/UNFPA 2016). The study revealed the power of social and religious norms (including sharia law) proscribing women's participation in politics and other areas of the public domain and reinforcing their "natural" role in the household. It also indicated that women are perceived as having fewer leadership qualities than men (UN Women/ UNFPA 2016).

43 The election law in 2011 introduced a gender quota on party lists for district and city council elections-a minimum of 30\% representation by either sex, plus a ranking system of candidates (FAO 2016; Muldoone and Casabonne 2017).

${ }^{44}$ See the website of Kyrgyz Republic Jogorku Kenesh, List of the Deputies. http://kenesh.kg/ru/deputy/list/35.

45 Based on the analysis of the Central Election Commission data for 2016 by Zulfia Kochorbaeva,Public Association Agency of Social Technologies. 


\section{Mainstreaming Gender in ADB Operations}

\section{A. ADB Gender Policy}

$\mathrm{ADB}$ is committed to ensuring gender-sensitive development that contributes to gender equality and women's empowerment. ADB has progressed from a women in development (WID) to a gender and development (GAD) approach, which sees gender as a crosscutting issue influencing all social and economic processes. ${ }^{46}$ The ADB Gender Policy emphasizes that economic growth alone does not guarantee gender equality outcomes. Specific investments in women and girls are also needed to reduce inequities and promote empowerment, with positive implications for socioeconomic development. Strategy 2030, ADB's long-term strategic framework, recognizes gender equality and women's empowerment as critical principles for achieving economic growth, reducing poverty, and supporting socially inclusive development. ${ }^{47}$

ADB is committed to ensuring that its operations are gender sensitive, grounded in gender analysis, and-where possible-gender transformative, enabling equal opportunities and outcomes for women and men. This commitment includes assisting partner country governments in (i) developing strategies, plans, and targets to reduce gender disparities; (ii) developing gender-integrated CPS; (iii) building gender capacity by recruiting gender advisors at the country level; and (iv) developing sector and project-specific gender action plans (GAPs) for all ADB projects.

ADB uses a four-tier gender categorization system to assess the extent to which projects integrate gender issues and clarify gender mainstreaming concepts to ensure consistent application and enable effective monitoring of ADB's gender performance. The categorization is applied "at entry" when projects are approved (Box 3).

\section{B. ADB in the Kyrgyz Republic}

1. Country Partnership Strategy

The Kyrgyz Republic joined ADB in 1994 and received 44 loans (\$1.2 billion) and 40 grants (\$662 million) from the Asian Development Fund (ADF) and six grants ( $\$ 7.5$ million) from

46 WID, adopted by many development agencies, was criticized because it treated women's issues in isolation from their relationships with men. This led to an industry-wide shift to a GAD approach, which focuses on the social relations between women and men and recognizes the importance of actively engaging men in changing inequitable gender norms. See ADB (2003) and Shahrashoub and Miller (1995).

47 The 2030 strategy stipulates that at least $75 \%$ of ADB's committed operations will promote gender equality by 2030 (ADB 2018c). 


\section{Box 3: ADB Gender Categories and Requirements for Gender Mainstreaming}

\section{Gender Equity Theme (GEN)}

- Directly supports gender equality and/or women's empowerment.

- The outcome statement in the project design and monitoring framework (DMF) explicitly mentions gender equality and women's empowerment, and/or the outcome performance indicators include gender indicators.

\section{Effective Gender Mainstreaming (EGM)}

- Outcome is not directly gender equality or women's empowerment, but still substantially integrated in the project design.

\section{Some Gender Elements (SGE)}

- Does not meet GEN/EGM criteria but has some direct and substantial benefits to women, or includes some gender-related design features in project design or resettlement.

\section{No Gender Elements (NGE)}

- No gender issues are integrated into the design.

Source: ADB. 2012. Guidelines for Gender Mainstreaming Categories of ADB Projects. Manila. https://www. adb.org/sites/default/files/institutional-document/33623/files/guidelines-gender-mainstreamingcategories-adb-projects.pdf.

the Japan Fund for Poverty Reduction (JFPR) (ADB 2018b). ADB strongly supported the government's efforts to remove constraints to growth and expand access to economic opportunities. The country's NSDS (2013-2017) and ADB's Strategy 2020 share a common goal of reducing poverty through inclusive growth (ADB 2013c).

ADB's operations in the country evolved to closely align with the government's strategy. Priority sectors were also identified based on recommendations in diagnostic studies, the availability of ADB resources, the capacity and ownership of the government counterparts, and complementarity with other development partners' programs (ADB 2012a). The CPS 2007-2010 focused on (i) road transport and communications; (ii) agriculture and natural resources; and (iii) education, as well as the crosscutting themes of private sector development, regional cooperation, and environmental sustainability. The energy sector was included in 2010.

The CPS 2013-2017 reaffirmed ADB's support to the Government of the Kyrgyz Republic in achieving its vision of poverty reduction through inclusive economic growth by (i) providing assistance to address key constraints to economic growth, (ii) improving the investment climate, and (iii) reducing disparities in access to economic opportunities. The priority sectors identified were (i) public sector management (PSM) for improving investment climate, (ii) transport and logistics, (iii) energy, (iv) water supply and sanitation, and (v) education and training. This CPS outlined ADB's commitment to mainstreaming gender, but it did not 
explicitly commit to mainstream gender in all priority areas; it identified specific gender gaps and challenges in women in governance and decision making, and gender dimensions of economic development. Accordingly, it identified actions to help implement the government's NAPGE, by increasing women's economic opportunities and female entrepreneurship (ADB 2013d). The next section reviews the progress in achieving the gender equality objectives in CPS 2013-2017, and highlights the gaps and missed opportunities.

The CPS 2018-2022 is now being implemented along with the government's new mediumterm strategy for $2018-2023^{48}$ and long-term vision for 2040 . This includes supporting the government to address the SDGs through (i) measures to reduce poverty and food insecurity; (ii) improved access to basic services that include health, clean water, sanitation, and quality education; and (iii) promotion of gender equality. ADB's Country Operations Business Plan for 2018-2020 remains aligned with the priorities of the CPS 2013-2017. ADB is continuing to support the five priorities from its previous CPS but has added a sixth-to reengage in agriculture through project financing to achieve a more inclusive, environmentally sustainable growth. A key objective of the CPS is to build climate and disaster resilience, with a focus on improving access to water resources. The strategy also pledges to address poverty and reduce inequalities by promoting job diversification, encouraging women's entrepreneurship, and improving the quality of secondary education and TVET.

\section{Mainstreaming Gender in ADB Priority Sectors in the Kyrgyz Republic}

This section reviews the five priority sectors for the CPS 2013-2017-PSM, transport and logistics, energy, water supply and sanitation, and education and training-through a gender lens. It outlines the current situation in mainstreaming gender and promoting gender equality through ADB-funded projects in the Kyrgyz Republic. It sets out key gender issues and concerns, outlines good practices and progress against ADB gender equality targets, and points to missed opportunities and entry points for gender mainstreaming in the CPS 2018-2022 and beyond.

\section{Public Sector Management for I mproving I nvestment Climate}

An ADB priority in the Kyrgyz Republic is to ensure that public institutions and processes are fit for their purposes. Under the 2013-2017 CPS, the key objectives are (i) working with the government to improve the business environment; and (ii) reducing barriers to business by promoting public-private partnerships, improving access to affordable financing, including providing business advisory services for female entrepreneurs.

To support these objectives, the Investment Climate Improvement Program (ICIP) was launched in 2008, with a $\$ 20$ million grant and technical assistance. The ICIP was to support sustainable economic growth through an improved investment climate and business environment. The first ICIP provided a diagnostic analysis to identify constraints to private

48 The government's priorities are (i) growth with macroeconomic stability, (ii) improved connectivity with regional neighbors and markets, (iii) development of SMEs, and (iv) diversification of industry (ADB 2018a). 
sector development, assess training needs for entrepreneurs, and provide concrete policy recommendations for improving business environment and investment climate (ICIP 2008). Subprogram 1 of the first ICIP had no gender elements (NGE), but subprograms 2 and 3, and all subprograms of the second phase were all classified as effective gender mainstreaming (EGM), and included measures to address obstacles faced by female entrepreneurs and promote equal access to SMEs (ADB 2011b, p.2). A Second ICIP phase was introduced in 2014.

Key issues for a gender-responsive planning and implementing public sector management (PSM) include the following:

\section{Creating Gender-Responsive Public Institutions}

Public institutions and processes are often considered "gender-neutral," but they often fail to take into account the different needs and experiences of women and men or to consider the gender-specific impacts of the decisions they make. Incorporating a gender lens in PSM is, thus, essential to ensure that public institutions do not reinforce gender disparities but rather promote gender equality (ADB 2012b, p.1). A gender-aware approach involves conducting gender analyses to inform planning. Consulting with women and men of different ages and social strata-including those who are often excluded, such as the poorest, disabled citizens, or marginalized ethnic minorities-allows integrating gender dimensions into all public management processes, such as planning, budgeting, and administration. ADB views the mainstreaming of GRB into the public sector as critical to achieving successful, sustainable gender equality laws and programs (ADB 2012b, p.1). GRB was introduced a decade ago by the Government of the Kyrgyz Republic, ${ }^{49}$ followed by an initial period of capacity development and pilot testing. However, it has yet to be formally mainstreamed in government policies, plans, programs, service delivery, and monitoring and evaluation. One key barrier is the limited authority, financing, and capacity of the national Gender Council to ensure that gender equality policies are properly developed and fully implemented.

\section{Promoting Women's Economic Empowerment through Entrepreneurship and Employment}

Women's labor participation has been declining over the past decade and female rates of unemployment are high. Women also account for a small percentage of total entrepreneurs in the Kyrgyz Republic and are faced with significant challenges, such as accessing business loans and appropriate training. Data collected by the ADB in 2017 found that women comprised less than half of all borrowers in partner banks, and that loans for female borrowers accounted for only $25 \%-43 \%$ of their total loan portfolio. Loan size is much smaller for women than men, ranging from just $5 \%-23 \%$ of male loans. The loan period is also much shorter for women than men, while the interest rates are higher than for men. Women's limited ownership of assets, such as land, is a key constraint in securing loans (ADB 2017d).

49 There have been three stages in the development of GRB in the country. From 2000-2005 the focus was on methodological development and the practice of citizen participation in discussions and formulation of budget initiatives was introduced. Between 2005 and 2012 national experts were engaged in the gender analysis of local and national budgets and developed approaches tailored for the Kyrgyz Republic context. This was followed by a process for systematizing GRB processes through measures that included the development of national and regional standards, capacity building of staff from the Ministries of Economy and Finance and building an ongoing dialogue on GRB with government agencies, civil society activists and businesses (A. Niyazova. 2015. Case Study: Gender Sensitive Budgeting. Innovative Solution Inc.) 
ICIP has included targeted approaches to address these critical areas. The key beneficiary group for the ICIP is female and male entrepreneurs-through improved access to financing and financial services and to export opportunities under the Generalized System of Preferences Plus (GSP+) and the Eurasian Economic Union. The Second ICIP subprograms 1 and 2 aimed to increase female entrepreneurs' access to business networks and market-based skills training, to reduce business-related costs. Subprogram 3 (ADB 2017e) includes genderresponsive actions, such as implementing the State Credit Guarantee Fund to increase bank lending in priority sectors and to enterprises owned and managed by women. The Second ICIP subprograms also aimed to enhance opportunities for women's employment, by setting targets of $43 \%$ women working in a full-time capacity on public-private partnerships in key agencies, and 30\% female staff in the Investment Promotion Agency (11 of 38 staff).

In addition, the Women's Entrepreneurship Development Program (WEDP), funded jointly by ADB and the Japan Fund for Poverty Reduction, has been particularly successful in supporting female-led SMEs, and provides an effective model for replication in other locations (Box 4).

Some efforts were made to facilitate the increased inclusion of women in employment areas dominated by men. For example, the Second ICIP included a component to strengthen the capacity of the Investment Promotion Vocational Education Agencies to focus on developing market-relevant skills, the TVET programs that enable women to enter nontraditional occupations, and including at least $20 \%$ women in the training of officials from relevant state bodies.

\section{Box 4: Scaling Up Female-Managed Small and Medium-Sized Enterprises}

The Women's Entrepreneurship Development Program (WEDP) was developed by the Asian Development Bank (ADB) and received \$1.5 million financing from the Japan Fund for Poverty Reduction. It was implemented by ADB and the Ministry of Economy (MOE). The WEDP aimed to enable the scaling-up of micro, small, and medium enterprises (MSMEs) managed by women in rural areas and small towns through capacity building and outreach, institutional development, and pilot testing of projects. As a result of WEDP, 630 female entrepreneurs received training on financial literacy, business planning, and leadership while 100 staff of public finance institutions were trained in gender awareness and addressing the needs of female entrepreneurs. In addition, 403 women received loans from public finance institutions as part of an initiative to pilot innovative, accessible microfinance products, which far exceeded the target of 50. Among WEDP's key achievements were (i) improved livelihoods for female entrepreneurs in rural areas through investment in the handcrafts industry; (ii) the provision of business advisory services for women entrepreneurs; and (iii) training in financial literacy, marketing strategies, and business management.

The project also recommended the introduction of gender-sensitive approaches for financial institutions, contributed to the amendments to the legislation on leasing, and made other institutional and policy recommendations to improve the enabling environment for female entrepreneurship. The government highlighted the positive outcomes of the project.

Source: ADB. Project Data Sheet of Kyrgyz Republic: Women's Entrepreneurship Development Project. https://www.adb.org/projects/46010-001/main\#project-pds (accessed 22 May 2019); ADB (2018d). 


\section{Entry Points for Gender Mainstreaming}

Ensure quality of information in project design, implementation, and evaluation. A comprehensive gender analysis of the MSME sector and the broader financial landscape should be conducted at the beginning of any project and should inform its design. As part of this process, participatory consultations should be held with relevant ministries, agencies, and CSOs. ${ }^{50}$ This is to better understand the strengths and gaps in gender knowledge, capacities, and mechanisms that need to be addressed among the program implementors and their target partners. The national gender specialist for the project should be on board at the onset of the project to facilitate these processes.

Design interventions to promote women's entrepreneurship. Providing support in the form of accessible, small, and micro bank loans and grants; and business trainings tailored to women's needs are often very successful in promoting female entrepreneurship (ADB 2014c). Existing or potential entrepreneurs will also benefit greatly from mentoring relationships and other forms of advice. Gender quotas should be promoted as an integral aspect of all MSME business grant and loan schemes to offset gender biases (e.g., because of male ownership of assets such as land, which may improve their access to credit). Provisions to increase outreach to poorer and/or ethnic minority women should be put in place.

Increase women's access to finance. Financing agencies, such as MFIs and banks, should create enabling conditions for women to access loans and grants. They should also support female entrepreneurs to transition out of micro into SMEs and access local, national, and regional markets. Measures should include facilitating access to small and micro loans and grants and offering business training to potential and existing female grantees. The successful Women's Entrepreneurship Development Program (WEDP) approach provides a model that could be adapted or replicated in other financial institutions.

Draw lessons from ADB's took kit on gender and micro, small, and medium-sized enterprises. The ADB gender tool kit on MSMEs (ADB 2014c) provides a useful guidance in designing gender-responsive projects on finance and MSMEs. As with the other tool kits, it includes a detailed discussion on why gender matters in MSMEs. It also guides in identifying social and gender issues during the concept stage and in undertaking gender analysis during the design stage. Finally, it offers entry points that the project team can consider in mainstreaming gender in MSME finance projects.

\section{Transport and Logistics}

ADB is the lead development partner in the transport sector in the Kyrgyz Republic, with the majority of its financial assistance concentrated in this sector. The main focus has been supporting the government in improving the transit potential of the country by integrating its national road infrastructure into major regional and international networks. ${ }^{51}$ ADB has also committed to work with the government to develop and implement a road safety action

50 Relevant agencies to consult include the following: Ministry of Labor and Social Development, National Statistics Committee, Investment Promotion Agency and the Trade Policy and Regulation Department under the Ministry of Economy, Ministry of Finance, National Bank of the Kyrgyz Republic, Ministry of Transport and Road, and Center for Judicial Representation.

51 Although the international and regional roads only account for $22 \%$ of public roads, they comprise around $50 \%$ of total road traffic in the Kyrgyz Republic. 
plan. There are approximately 34,000 kilometers $(\mathrm{km})$ of roads in the Kyrgyz Republic, which include $18,800 \mathrm{~km}$ of public roads and $15,190 \mathrm{~km}$ of private industrial routes. ${ }^{52} \mathrm{ADB}$ has previously supported the rehabilitation of $831 \mathrm{~km}$ of road on five regional transport corridors in the Central Asian region border to increase trade and economic activities through better connectivity (ADB 2013c). ADB's current interventions in the transport sector focus on rehabilitating regional corridors and maintaining the road network. The most significant project is the Central Asia Regional Economic Cooperation (CAREC) Corridors 1 and 2.

\section{Box 5: ADB Investments in the Transport Sector of the Kyrgyz Republic}

In 2016, the Asian Development Bank (ADB) approved \$98.1 million for the Central Asia Regional Economic Cooperation (CAREC) Corridors 1 and 3 Road Project. By rehabilitating around 70 kilometers of roads, the project will help reduce the cost of transport between the southern and northern regions of the country and shorten the route between Kazakhstan and Tajikistan. With the \$10 million Regional Improvement of Border Services Project, ADB is supporting the construction of border crossing point facilities that meet international standards at Karamyk on the Kyrgyz-Tajik border. In 2019, the CAREC Corridor 3 Improvement Project will rehabilitate the Bishkek northern bypass road. ADB will assist the government in (i) road sector reform, (ii) designing and implementing a pilot road asset management system, and (iii) conducting a road safety campaign. A new $\$ 20$ million road maintenance project is planned for 2020 . An additional phase of the project will focus on road safety, asset management, and maintenance.

Sources: ADB. 2018. Kyrgyz Republic. Asian Development Bank Member Fact Sheet. Manila. https:// www.carecinstitute.org/wp-content/uploads/2018/12/2017-PUBL-Kyrgyz-Republic-Fact-Sheet.pdf; ADB. CAREC Corridor 3 (Bishkek-Osh Road) Improvement Project, Phase 4. Project Data Sheet. Manila. https://www.adb.org/projects/45169-003/main\#project-overview (accessed 17 November 2019).

As the ADB Tool Kit on Gender and Transport notes, there is a common misperception among project planners and implementers that transport infrastructure and services are "gender neutral," equally benefiting men and women (ADB 2013b, p.1). Yet, they are experienced differently by women and men, and girls and boys as there are often significant differences in their travel patterns, access to transport, and utilization of transport options. Factors such as disability or travelling with small children may also affect people's transport requirements. Transport projects and investments, therefore, should be gender-inclusive, enabling the mobility of all people for different purposes (ADB 2013b, p.1). So far there has been little evidence of the integration of gender dimensions into transport-related projects funded by ADB in the Kyrgyz Republic, with most being under the category of NGE. However, a comprehensive gender action plan (GAP) has been developed for the CAREC project. The GAP calls for the establishment of reliable, sex-disaggregated data and reporting mechanisms to inform gender-responsive project planning and implementation. It also sets out an effective and sustainable process, ensuring that a gender specialist is appointed to implement the GAP, include GAP targets for review visits, and supervise the community facilitators.

52 Transport Corridor Europe-Caucasus-Asia (TRACECA). 2013. Logistics Processes and Motorways of the Sea II LOGMOS Master Plan-Annex 9.1. Country Profile. Baku. http://www.traceca-org.org/fileadmin/fm-dam/ TAREP/65ta/Master_Plan/MPA9.1KY.pdf. 
Key issues for gender-responsive planning and implementation on transport and logistics in the Kyrgyz Republic include the following:

\section{Access, Mobility, and Safety}

When planning and constructing major roads it is important to consider who will be using them, how, when, and why. As women are most likely to use public transport than men, it is vital that their needs and perspectives inform planning, design, and construction. Emerging evidence indicates that women's mobility in the Kyrgyz Republic is more limited compared to that of men due to the lower likelihood that they drive private vehicles or can afford the cost of private transport. A gender analysis on gender inclusion in public transport, conducted by the European Bank in Osh city, identified differences in transport use and access between men and women. A key difference was that women were more likely than men to choose private minibus services over public transport because they are faster, more reliable, and cover a wider area (Bankwork Network 2018). Although limited to one city, these findings suggest that Kyrgyz women are heavily reliant on transport services for daily journeys to work and other locations such as their children's schools.

Given the large number of people living in rural areas-many of whom are women-it is vital to address the needs of this often neglected group. According to the Rural Access Index, 76\% of rural residents in the Kyrgyz Republic live within $2 \mathrm{~km}$ of the nearest all-season road, while the remaining 0.8 million people have no access to transport routes. ${ }^{53}$ This limits the mobility of male and female agricultural producers who could not bring their products to the larger towns and cities and, therefore, obliged to rely on middle people. The ADB Tool Kit on Transport and Gender notes that rural women often have poor access to transport networks and public transport. This can leave them isolated from health care facilities, including maternity hospitals, which is especially problematic for women with high-risk pregnancies or childbirth complications. Waiting for often unreliable public transport services can also intensify women's time poverty and undermine their economic potential as they may be less likely to take up well-paid employment outside the immediate vicinity in which they live (ADB 2013b, p.1).

It is important to bear in mind the gender-specific implications when roads are constructed, with men and women experiencing different impacts. For example, enhancing the rural population's access to national and regional transport corridors can potentially contribute to a rise in the rates of male migration. While this may increase their economic potential, it can also lead to an increased workload for households with female heads and in farms (ADB 2013b, p.1). It can also bring many positive impacts for women and men. The evaluation of the 2013-2017 CPS reports that, following improvements to the CAREC road corridor, the overall student attendance rate rose from $92 \%$ in 2007 to $94 \%$ in 2013 . However, the lack of gender-disaggregated data means that the specific implications for female and male students were not captured (ADB 2018d).

Safety on roads and public transport also needs to be assessed through a gender lens. As women are often more likely to be passengers or use public transport to access schools, hospitals, or workplaces, they may need to walk or wait for public transport alongside roads and may also

53 Rural Access Index is a headline transport indicator, which highlights the critical role of access and mobility in reducing poverty in poor countries. It is one of several Transport Headline Indicators endorsed by the World Bank Transport Sector Board in 2003. https://datacatalog.worldbank.org/dataset/rural-access-index-rai. 
have small children with them (ADB 2013b, p. 1). They may need to cross major roads to reach their destinations. Elderly women and men, and children going to and from school may also use roads in this way. If there is no provision of suitable walkways, bridges, or bus stops, this raises serious safety concerns for these pedestrians in addition to issues on accessibility (ADB 2013b, p.1). At night, the risk increases if appropriate lighting is not provided. Male road users will also be exposed to potential risk if no mandatory road safety measures are in place for drivers, or if road signs and lighting are inadequate. According to the evaluation of the CPS 2013-2017, traffic accidents have declined from 14 per 250 annual average daily traffic in 2006 to 14 per 288 in 2013. The data are not disaggregated by gender or type of accident but given the higher prevalence of male drivers, it is likely that fewer men were at risk of injury or death due to improved road safety (ADB 2018b).

Personal safety and harassment on public transport are significant concerns for women. Women are often subjected to sexual and other forms of harassment when using transport services. Therefore, for women, perceptions of safe travel go beyond physical road safety to include risks of harassment, stalking, sexual assault, or rape (ADB 2015).

\section{Enhancing Employment Opportunities}

The rapidly growing transport sector could potentially offer employment opportunities to both women and men in both administrative and technical areas (ADB 2013b, p.1). Theoretically, women are encouraged to apply for more technical posts such as in engineering, but in practice they tend not to do so. According to the latest figures, only $4.9 \%$ of all those employed in the transport and cargo sector are women, while women account for $23.2 \%$ of employees in the Ministry of Transport and Communication, all in administrative positions (NSC 2016b). According to the trolleybus departments in Bishkek, as of 2019, only around $10 \%$ trolleybus drivers were female (33 of 337). However, there is an increasing number of female taxi drivers in Bishkek and, taxi service for women was introduced where drivers are all female. ${ }^{54}$ CAREC's project GAP calls for a targeted approach to improve gender equity among transport staff, including at management levels. Indicators include $30 \%$ women to be represented at decision-making levels in project-related activities and $50 \%$ women in project teams. Periodic monitoring of progress had not yet started at the time of writing.

\section{Entry Points and Recommendations to Gender Mainstreaming in the Transport Sector}

Integrate gender at all levels of transport planning, implementation, and evaluations. ${ }^{55}$ Transport planners and implementing agencies should take proactive approaches to integrating gender dimensions at all stages of projects-from inception and design to monitoring and evaluation. Urban, rural, and national transport initiatives should all begin with a comprehensive gender analysis to identify the specific dynamics, needs, and user patterns of men and women, as well as gendered cultural and social norms that may affect access. Following the initial gender analysis, gender-disaggregated data should be regularly collected to monitor accessibility and satisfaction levels, and the other indicators. In rural and urban areas, project implementers should collect and monitor sex-disaggregated transport and travel pattern statistics and carry out periodic surveys of public transport user demands

54 Gulfia Abdullaeva, Personal communication. May 2019.

55 For more detailed entry points for gender mainstreaming in the transport sector, see Appendix 1. 
in rural areas. Consult with diverse groups of women and men so that their voices and experiences are taken into account in project design and implementation, and to identify and respond to transport needs in both rural and urban areas. A gender analysis should inform planning for road alignments, including feeder roads, footpaths, footbridges, and features such as roadside rest points (with toilet facilities for women and men) and roadside market facilities. Achieving a gender balance at the level of policy development, project planning, implementation, and monitoring will also help ensure both female and male perspectives inform these processes.

Ensure that transport infrastructure is accessible, safe, and convenient for all. To reduce pressure on urban roads and to facilitate mobility for residents of cities and towns, the price of public transport tickets must be affordable for all-including the elderly, students, and poorer women and men. These services must also be accessible to differently abled groups. This means introducing public transport schedules and pricing systems that respond to the needs of all users-including affordable off-peak, multiple trip, and group traveler ticketing. Urban transport infrastructure should be designed to meet the specific needs of women and differently abled people-e.g., sidewalks should be wide enough for prams or wheelchairs. When designing access routes to highways, including pedestrians and two-wheelers, it is also important to consider putting dedicated pedestrian and/or two-wheeler lanes near settlement areas and ensure that transport stops are positioned and constructed with different people's needs in mind, enabling them to access, wait, and alight safely. These areas should be well lit, sheltered, and away from busy traffic flows. It may also be necessary to create separate waiting areas for women and men in compliance with cultural and religious practices. Basic amenities, such as separate disabled-access toilets, must also be provided for both women and men in major national and regional transport routes and in public transport depots.

Safety for all must be at the heart of all transport design and must be monitored regularly. Roads must be designed with both drivers and pedestrians in mind. Designs should have carefully planned, safe, well-lighted crossing points, and wide pavements for women of all ages who are often more likely to be on foot, as well as clear signage and excellent lighting for (often male) drivers. To improve safety for women and girls on public transport, features such as security cameras, women-only spaces and entrances, and panic buttons at stations and on buses should be included at the design stage. The importance of safety should be reinforced through a zero-tolerance attitude to all forms of gender-based harassment in public spaces. This should be supported by providing training on appropriate responses to sexual harassment for public transport staff and the local police, and raising public awareness on these issues.

Explore opportunities for increasing women's economic empowerment in the transport sector. The introduction of measures to encourage gender parity in transport sector employment should be mandatory for all project implementers and public transport operators. Measures should include (i) targets for female recruitment, (ii) flexible working policies, (iii) provision of crèches and subsidized childcare for women with young families, and (iv) strict antidiscrimination regulations in line with the national laws and international commitments such as CEDAW and the BPFA. Assessments should be conducted to identify "quick win" opportunities for women's employment, such as including rural women in road construction and related service provision. These should also highlight areas for gender-responsive investment-such as providing technical training to female students and employees. It is also vital to address underlying gender biases, which may give undue privilege to male promotion to more senior, better-paid positions. Practical strategies, such 
as introducing sector-wide targets for women's involvement in skills training, can also create more gender-balanced management structures (ADB 2013b, p.1). In addition, employment targets should be established for women in construction and higher-skilled urban transport sector jobs generated by the project, such as station attendees, ticket collectors, drivers, and inspectors.

Support awareness-raising and capacity building activities for the government and sector partners. If gender mainstreaming is to be viewed as a priority within the transport sector, it is essential to create awareness and deep understanding of why gender dimensions are critical to the success of all initiatives. While it is important for executing and implementing agencies to hire dedicated GFPs who can develop GAPs and ensure that these are translated into practice, all staff members should be responsible for integrating gender into their work. Where possible, awareness-raising activities should be continuous through regular trainings and discussions so that the issues remain on everyone's agenda-from technical and frontline staff to senior managers and transport sector policy makers. Those in decision-making positions also need to recognize the importance of putting adequate financial resources behind staff training; and in the design, dissemination, implementation, and monitoring of GAPs.

Be guided by ADB's transport initiatives and tool kits. ADB's Sustainable Transport Initiative (ADB 2010) and Tool Kit on Gender and Transport (ADB 2013b) are still relevant and can guide in mainstreaming gender in the sector. The Sustainable Transport Initiative highlights the approaches to addressing the social dimensions of transport, including gender mainstreaming, participation, and negative social impacts (Box 6.) The tool kit (i) discusses why gender is important for the transport sector; (ii) offers guidelines for integrating gender into ADB operations, conducting gender analysis, policy dialogue, and undertaking capacity development; (iii) identifies gender entry points for transport subsectors; and (iv) outlines ways to mitigate social risks.

\section{Box 6: Key Points from Gender and Transport Tool Kit}

Effective approaches for addressing the social dimensions of transport include:

(i) More participatory approaches to project planning and project strategies to protect against associated HIV/AIDS and human trafficking risks;

(ii) Incorporating complementary development programs and community-based maintenance;

(iii) Improving transport services;

(iv) Providing improved facilities, such as public toilets and pedestrian and bicycle lanes to make transport accessible and safe for all users and social groups, including women and the elderly;

(v) Applying core labor standards; and

(vi) Using tariff and subsidy options to increase access for vulnerable groups.

Source: ADB (2010). 
The Kyrgyz Republic is the primary clean energy source of Central Asia, with the majority of electricity generated by hydropower. The NSDS (2013-2017) placed strategic importance on the energy sector to achieve sustainable human development, increase production for more reliable domestic electricity supply, and higher electricity exports while also improving state regulation of the sector and the management of energy companies. The government is working closely with development partners-including ADB-to rehabilitate outdated power sector assets and improve overall energy supply. Government measures also included an increase in energy compensations to pensioners, an energy subsidy scheme for populations living in mountainous regions, and incremental rises in wages of government employees earning less than Som5,000 (World Bank 2014).

The ADB CPS for the Kyrgyz Republic 2013-2017 supported the NSDS (2013-2017), with a focus on technical and financial rehabilitation of the energy sector. According to the 2018-2022 CPS, it will continue to work with the government to improve the reliability and financial sustainability of electricity supply, by rehabilitating and upgrading existing key assets, including hydropower plants; and undertaking institutional and technological reforms aimed at improving efficiency in the energy sector (ADB 2018a).

\section{Box 7: ADB Investments in the Energy Sector of the Kyrgyz Republic}

\section{Power Sector Rehabilitation Project-The Toktugul Hydroelectric Power Plant}

ADB funded the three phases of the rehabilitation of the Toktogul Hydroelectric Power Plant, the largest and most important power plant in the Kyrgyz Republic, which produces $40 \%$ of the country's average electricity output. The total budget of $\$ 275$ million comprised $59.38 \%$ of the total Country Partnership Strategy program budget during 2012-2017.

\section{The Uch Kurgan Hydropower Plant Modernization Project}

ADB is supporting the modernization of the Uch Kurgan hydropower plants (HPPs), one of the oldest HPPs in Jala-Abad province, South West Kyrgyz Republic. The modernization project is scheduled to start in 2020. In addition to modernizing the existing asset, a new and smaller HPP will be constructed at the Uch Kurgan irrigation canal.The project aims to (i) increase supply of renewable energy to national and regional power systems; (ii) improve energy security by enhancing supply reliability; and (iii) enhance understanding on sustainable clean energy development, climate change adaptation, and mitigation measures. The fully modernized Uch Kurgan HPP will generate an additional 451 gigawatt-hours per year with increased $20 \%$ efficiency. It will increase the reservoir volume from 7 million cubic meters to 22 million cubic meters and will reduce by 52,428 tons the emission of carbon dioxide $\left(\mathrm{CO}_{2}\right)$ per annum.

Sources: ADB. Power Sector Rehabilitation Project. Project Data Sheet. Manila. https://www.adb.org/ projects/44198-013/main\#project-pds (accessed 18 November 2019); ADB. Toktogul Rehabilitation Phase 2 Project. Project Data Sheet. Manila. https://www.adb.org/projects/46348-003/main\#projectpds (accessed 18 November 2019); ADB. Toktogul Rehabilitation Phase 3 Project. Project Data Sheet. Manila. https://www.adb.org/projects/49013-002/main\#project-pds (accessed 18 November 2019); ADB. Uch Kurgan Hydropower Plant Modernization. Project Data Sheet. Manila. https://www.adb.org/ projects/49240-001/main\#project-pds (accessed 18 November 2019). 
The Toktogul Hydroelectric Power Plant project was classified as NGE and as there were no inputs from the gender advisor, no gender-specific results were recorded. The hydropower plant (HPP) project is classified as having some gender elements (SGE), from indirect impacts gained through increased access to energy at the household level. Yet, there is no GAP for the HPP and no targeted efforts to mainstream gender.

Key issues for gender-responsive planning and implementation on current and future energy sector projects in the Kyrgyz Republic include the following:

\section{Access and Affordability}

Women and men often have different energy needs and concerns; it is vital to take these into account when planning and implementing all projects. The ADB Gender and Energy Tool Kit notes that power interruptions and unreliable quality of supply, resulting in prolonged outages or shortages, can make it difficult for women to maximize potential opportunities. For example, the functioning of home-based microenterprises can be hampered (ADB 2012c). Poor availability of energy often adds to women's unpaid care burden as they may be required to search for firewood or spend time sourcing and purchasing low-cost solid fuel. Energy costs must also be realistic and inclusive, allowing access to services by poor households, with those headed by women potentially and disproportionately disadvantaged.

One intended outcome of the Uch Kurgan Powerplant project is the improvement of households' access to energy, which in turn is expected to reduce the burden of unpaid care work for women by reducing the time needed to collect traditional fuel and enabling households with appliances to use them more often. Improved access to electricity should also improve the services provided by health centers and schools, by making heating more efficient, and electricity-operated equipment more reliable. This should also improve health and educational outcomes of household members, and indirectly support women who are responsible for the care of family members.

\section{Health and Safety}

According to a UNDP survey in the Kyrgyz Republic, coal, wood, and dung are the most common source of energy at the household level, with fewer people using electricity (UNDP 2013). Burning fossil fuels is associated with health risks-for example, dung emits toxic gases when burned. Since they spend more time at home, women and children are affected most severely by indoor air pollution due to prolonged exposure to smoke from the burning biomass. This leads to an increased risk of acute viral respiratory diseases among children. Women and children are also more exposed to the risk caused by inefficient heating appliances and furnaces (ADB 2012c).

\section{Entry Points for Gender Mainstreaming in the Energy Sector}

Ensure gender is integrated at all levels of energy planning, implementation, and evaluations. Energy planners and implementing agencies should take proactive approaches to integrating gender dimensions at all stages of projects-from inception and design to monitoring and evaluation. Well-designed gender analyses and sex-disaggregated baseline studies should be conducted at planning stage for all energy sector projects to understand demographic patterns and to identify the different energy needs of women and men. 
Diverse groups of women and men should be consulted, and their voices and experiences taken into account during project design and implementation-to identify and respond to the transport needs in both rural and urban areas. Achieving a gender balance at the policy level development, project planning, implementation, and monitoring will also help ensure both female and male perspectives inform these processes. The gender-specific data should inform the project's design and the setting of targets. It also forms a critical foundation for monitoring project activities and impacts during project implementation. Sex-disaggregated databases of potential and existing customers should also be maintained by energy agencies and utilities to capture the differences in energy use and needs, payments, and other servicerelated issues. Sex-disaggregated data should also be recorded for those using complaints and query hotlines.

Ensure universal access to affordable energy. It is vital to ensure that energy supplies are accessible to all-by extending the electrical grid to widen access to poor households, including those headed by women especially in rural areas. Household energy costs must also be inclusive. Strategies include (i) providing affordable credit for household connection, (ii) creating funds to support access for the poor, (iii) ensuring that tariff levels reflect the poor women's income levels, and (iv) holding gender-inclusive public consultation to assess women's opinions and preferences on affordability issues.

Promote women's employment and enterprise development in the energy sector. Investments in the energy sector could also potentially result in employment opportunities for women, whether through MSMEs for renewable energy products or through job creation in energy companies. ADB could consider developing pilot programs to support women entrepreneurs in the energy sector to learn new technologies, such as training rural women as village technicians in the sale, construction, and assembly of renewable energy systems. These processes could be supported by providing incentives, such as microfinance, MSME financing, tax benefits, and others.

The project's GAP can also support female recruitment by providing quotas and encouraging the active recruitment of women into the energy sector. Initiatives could include setting targets for women's employment, not only as meter readers and in customer care but also as technicians and managers. Employers should be encouraged to provide technical and vocational training for women. Women's participation in the energy sector should also be linked to gender-aware educational interventions, such as scholarship programs that encourage female students to choose higher education courses in engineering and other technical areas that will be of benefit to the energy sector.

It is essential that companies uphold the rights of female employees by complying with the core labor standards and/or appropriate labor laws on equal employment opportunities, equal pay for work of equal value, and women's on-the-job health and safety. It is also vital to provide separate facilities for women, including separate toilets, in project sites. The provision of facilities such as crèches, subsidized childcare, and flexible working hours may also help to encourage more women to apply for jobs within the energy sector. Awareness-raising and in-house technical and management training are also needed to address implicit biases that may prevent women's consideration for senior posts.

Amplify women's voices in energy planning and implementation. Women are often primary users of energy but their decision-making power in the household and communities is often 
restricted, reducing their voice in determining spending levels and type of service in the area of clean and renewable energy. Promoting women's voices at these levels through consultation and other methods and ensuring their representation in local and national governance, is vital. It is important to hear from women what types of energy they prefer and what times they would like to receive an energy supply, if their access is restricted. Entry points for promoting women's voices include increasing women's participation in electricity cooperatives, in user groups and/or committees; and setting targets to promote women's participation.

Seek guidance from ADB's gender tool kit on energy to mainstreaming gender in the sector. The gender tool kit on energy (ADB 2012c) remains a very useful resource for addressing gender considerations in energy projects. The tool kit provides (i) detailed discussions on why gender matters in the energy sector; (ii) guidance in developing gender-responsive energy services; (iii) key actions in the different ADB project cycles, including identifying gender issues in the initial poverty and social analysis, and in conducting a detailed gender analysis during the project design phase; and (iv) suggested questions for gender analysis (Box 8).

\section{Box 8: Key Points from the Gender and Energy Tool Kit}

\section{Policy and Institutional Capacity Development}

- Public consultation on energy policy, with participation by the poor and women,

- Gender-responsive approaches adopted in energy policy or strategy, and

- Institutional capacity of energy agencies and utilities built to provide gender-responsive services.

Power Generation, Transmission, and Distribution in Conventional Energy

- Energy access expanded for poor households,

- Energy-based women's enterprises established and are operating,

- Employment for women generated in the energy sector,

- Gender-sensitive user-education programs conducted,

- Energy service delivery improved for the poor and low-income households,

- Women's involvement as service providers in the energy sector increased,

- Women's participation in local public-private partnership initiatives increased, and

- Gender-responsive corporate social responsibility conducted.

\section{Rural Electrification}

- Energy access by the rural poor women and men increased and expanded;

- Women's participation in decentralized, community-managed distribution models enhanced;

- Women's energy-based rural entrepreneurship at the cottage and village levels developed; and

- Service delivery capacity transferred to the rural poor women 
Box 8 continued

\section{Renewable Energy}

- Access of the poor, rural women, and men to renewable energy systems and technologies improved;

- Women trained and employed as service providers in renewable energy systems and technologies;

- Gender mainstreamed in climate-mitigation financing schemes; and

- Targeted investments provided to maximize gender equality results of renewable energy

\section{Energy Sector Development, Energy Efficiency, Energy Trade}

- Energy efficiency at the household level increased with women as active change agents,

- Poor and vulnerable communities benefited from sustainable energy-efficiency enhancement measures, and

- Poor households benefited from energy trade among countries

Source: ADB (2012c).

\section{Water Supply and Sanitation}

The Government of the Kyrgyz Republic has noted the importance of taking adaptive measures to safeguard and improve water resources and sanitation in its NSDS. Currently, around $40 \%$ of the rural population does not have access to safe drinking water and water quality is often poor as $42 \%$ of rural water is untreated (ADB 2018a). The existing resources are under increasing pressure as the government's Second National Communication has identified impacts on water resources as one of the most severe climate change risks facing the country. There are also significant gaps in sanitation provision: less than a third of the population has access to centralized sewerage systems and this decreases to $0.4 \%$ in the most populous Osh region. Challenges include an inadequate legal and regulatory framework, the weak capacity of service providers, and inadequate incentives for water and sanitation staff. The government estimates that water-related diseases cost the country $\$ 70$ million annually (ADB 2018a).

Donors, such as ADB, have therefore prioritized investment and technical assistance in these areas (EBRD 2013). ADB is placing emphasis on support for sustainable water and sanitation solutions for the Kyrgyz Republic. This commitment is reflected in the 2018-2022 CPS, which maps out a twin-track approach to (i) increasing access to clean drinking water and building a centralized sewerage system in urban and rural areas, and (ii) improving the resilience of natural water resources to support rural livelihoods (ADB 2018a). Major programs relating to these two related areas are presented in Box 9 and Box 10.

On gender mainstreaming in water and sanitation projects, there is a GAP for the Climate Change and Disaster Resilient Water Resources Sector Project, which has an EGM categorization and is focused on responding to user needs. An initial stakeholder analysis was conducted to identify the needs of the beneficiaries and other key stakeholders, and to define roles and responsibilities for strengthening participation in project design and implementation. 


\section{Box 9: ADB Investments in Water and Sanitation Provision in the Kyrgyz Republic}

Issyk-Kul Sustainable Development Project

This 8-year project aimed to preserve the environment of Issyk-Kul Lake to reduce the impacts of tourism, and to expand and improve wastewater systems in the urban centers of Balykchy, Cholpon-Ata, and Karakol around its shoreline. ${ }^{a}$ Its overall budget was $\$ 37.5$ million.

Issyk-Kul Wastewater Management Project (IWMP)

This project began in 2018, with $\$ 30.5$ million financing and possible cofinancing of $\$ 11.5$ million. In addition to expanding the provision of water and sanitation at the household level, IWMP focuses on rehabilitating and creating sanitary facilities in schools while the Country Partnership Strategy will expand ADB support to improve water sewerage systems in health centers and hospitals, especially maternity hospitals.

${ }^{a}$ Issyk-Kul Lake is an area of outstanding natural beauty and is one of the country's most popular tourist destinations with over 750,000 visitors in 2013. (Based on a project description in an ADB website.)

Sources: ADB. Issyk-Kul Sustainable Development Project. Project Data Sheet. Manila. https://www.adb. org/projects/41548-013/main\#project-pds (accessed 18 November 2019); ADB. Issyk-Kul Wastewater Management Project. Project Data Sheet. Manila. https://www.adb.org/projects/50176-002/ main\#project-pds (accessed 18 November 2019).

\section{Box 10: ADB Investments in Sustainable Natural Water Resources and Resilience}

Climate Change and Disaster Resilient Water Resources Sector Project (CCDRWR)

This project has a budget of $\$ 38.6$ million. The project aims to strengthen climate change and disaster resilience in infrastructure and water sector. It has the following output: (i) design and build climate change and disaster-resilient irrigation infrastructure; (ii) strengthen irrigation management arrangements; (iii) enhance and strengthen water users associations; and (iv) enhance government capacities and systems. The intended project outcomes are improved water security and increased resilience to climate change and disaster.

Source: Based on a description on ADB website. https://www.adb.org/projects/51081-002/main\#projectpds.

Ongoing consultations are being conducted to ensure that any concerns from the poor, vulnerable, and excluded groups are addressed and incorporated into the project design and implementation. The Issyk-Kul Sustainable Development Project (ISDP) was categorized as EGM and a GAP was prepared for both phases-to ensure that the specific needs of female and male service users are taken into account, to raise public awareness in gender-responsive ways, and to improve women's representation among the water company staff. 
Key issues for gender-responsive planning and implementation on water and sanitation (including sustainable natural water resources and resilience) in the Kyrgyz Republic include the following:

\section{Access and Affordability}

Studies show that improving women's access to water means that they have more time for income generation, skills building, leisure, and time to responding to the needs of their families. ${ }^{56}$ In ISDP projects, women comprise at least $50 \%$ of dwellers in the target communities of Karakol, Balykchy, and Cholpon-Ata, who now have access to water supply and sanitation. The GAP for ISDP Phase 1 set targets for the provision of safe sanitation for women and girls of reproductive age at household levels and in institutions, such as hospitals (particularly maternal health wards) and schools. It also highlights the need to ensure that the frequency of collecting solid waste is increased, particularly in poor households headed by women.

\section{Conducting Gender Analyses and Collecting Sex-Disaggregated Data}

Water and sanitation services must be planned and developed with male and female end users' needs. As the primary collectors, users, and managers of water, women are often most aware of their own and their family's needs, so they must be included in consultations and in local and national decision-making bodies. Consultations must be held at women's convenient times to facilitate attendance of those with small children, for example, by providing crèches. There are emerging examples of good practice. The GAP for IWMP sets out processes to better understand the needs of potential users of water and sanitation services, with attention to gender dimensions. These include gender-sensitive consultations and public awareness campaign on the project, with a target of at least $40 \%$ female participation in each public meeting, consultation, or awareness campaign activity. ${ }^{57}$

The CCDRWR's GAP also sets out provisions to collect and utilize sex-disaggregated data for planning, implementation, and monitoring. There are also efforts to strengthen gendersensitive customer relations at the community level, by ensuring there are at least $50 \%$ female staff in each vodokanal's customer care unit and that each unit has a consumer grievance redress mechanism, with clear gender-sensitive procedures, to ensure the presence of female members of the grievance committee when requested by a female consumer, and recording of the consumer's gender, when complaints are filed and actions are taken. ${ }^{58}$

Understanding any gender differences in how women and men use water, and their attitudes toward conservation of natural resources, is vital to developing effective adaptation strategies. A failure to understand the social impacts of climate change and environmental degradation to the vulnerable groups can result in unmitigated risks. The lack of constructive mechanisms to allow the equitable access to natural and social resources-in the context of the challenges of climate change-could lead to a sharp increase in social conflicts. Ensuring gendersensitive and socially inclusive disaster risk management must be an integral component of

56 ADB. Gender Checklist: Water Supply and Sanitation. https://www.adb.org/sites/default/files/publication/28735/ gender-checklist-water.pdf.

57 See the IWMP GAP, 2018-2019. https://www.adb.org/projects/documents/kgz-50176-002-gap.

58 Targets are set out in the GAP of the Climate Resilience and Disaster Risk Reduction Project. 
the project by including guidelines for consulting with women and other vulnerable groups during project planning.

\section{Building Capacity on Gender Mainstreaming for Water and Sanitation Staff}

Integrating gender into water and sanitation projects-whether focused on household service provision or protecting natural resources-requires a high level of awareness and understanding among the staff, from frontline delivery to high-level management. The GAP for the IWMP emphasizes capacity building for staff in two key areas: (i) technical training for female staff (particularly those in senior positions); and (ii) training in gender awareness for vodokanal staff, key city or municipality staff, and technical working committee members. The GAP includes a target of $95 \%$ of vodokanal staff for both Balykchy and Karakol and each of their local working committees, and $50 \%$ of relevant city or municipality staff to acquire basic knowledge on gender mainstreaming. Women leaders, including 52 female staff from the mayors' offices, have also been involved as program partners and were trained as part of this initiative. The GAP of the CCDRWR emphasizes that contractors do no harm, practice social inclusiveness, and actively promote equality. It also stresses that civil works contractors must be committed to (i) hiring local labor, (ii) not using child or forced labor, (iii) providing gender sensitivity trainings to workers to ensure women-friendly working conditions for female workers; and (iv) implementing zero-tolerance for drug use and use of prostituted women in work camps. ${ }^{59}$

\section{Building Climate Resilience and Awareness among Rural Women}

Studies show that women are often the most vulnerable to climate change impacts because they lack access to relevant knowledge and to climate-resilient products and approaches. Female farmers living in remote rural areas are often at most risk from weather-related shocks, such as drought and extreme events, such as flooding and earthquakes. The CCDRWR GAP highlights the importance of training women-particularly female farmers-in climate awareness and adaptation. It calls for at least $30 \%$ women out of a total 500 farmers and community members to have improved knowledge of disaster and climate-resilient agricultural practices including legal rights, financial products, and value chains. It also sets targets for the inclusion of female Ministry of Education and Science staff in trainings in disaster risk management practices (see the CCDRWR's GAP for 2018-2019).

\section{Entry Points for Gender Mainstreaming in Water Supply and Sanitation}

Ensure that gender is integrated at all levels of water and sanitation planning, implementation, and evaluations. Water and sanitation planners and implementing agencies should take proactive approaches to integrating gender dimensions at all stages of projectsfrom inception and design to monitoring and evaluation. They must ensure that (i) water and sanitation services meet the specific needs of female and male users; and (ii) understand their preferences in terms of type of service and, in some cases, location of shared resources such as pumps, wells, and latrines. It may also mean setting appropriate tariffs that do not exclude the poor households (including those headed by females) and introducing subsidized financing arrangements and other inclusive strategies for the most vulnerable members of

59 ADB. Climate Change and Disaster Resilient Water Resources Sector Project Gender Action Plan, 2018-2019. ADB. Manila https://www.adb.org/projects/documents/kgz-51081-002-gap (accessed 18 November 2019). 
communities. Well-designed gender analyses and sex-disaggregated baseline studies should be conducted with diverse groups of women and men at the start of planning to capture the needs and respond to potential barriers. The gender-specific data should inform the design of project interventions and the setting of targets. The data will also become a critical foundation for monitoring project activities and impacts during project implementation.

Where possible, water service providers should maintain sex-disaggregated databases of potential and existing customers to capture differences in water use, water needs, payments, and other service-related issues. Feedback mechanisms that are accessible for both female and male users must also be developed. Sex-disaggregated data should also be recorded for those using complaints and query hotlines.

Increase women's access to training and employment opportunities in the water and sanitation sector. Measures, such as targets for female recruitment, working policies, and technical training should be introduced in all ADB-funded water and sanitation sector projects by building on existing efforts in this area. Implementing agencies need to comply with antidiscrimination regulations, in line with the national laws and international commitments, such as CEDAW and the BPFA. ADB could also support the development of recruitment processes that remove gender biases and offer a more level playing field between women and men. Any gender biases that may favor male promotion to more senior, better-paid positions should also be addressed. ADB could consider supporting needs assessments as the basis for developing more targeted training programs aimed at strengthening women's position in the sector. Practical strategies, such as the introduction of sector-wide training targets, can also help create more gender-balanced management structures.

Increase women's participation in decision making. Women are often the primary users of water and sanitation services, however, in the Kyrgyz Republic, they currently have minimum involvement in water user groups (WUGs). As part of the ADB's reengagement with sustainable agriculture, CPS 2018-2022 commits to enhancing women farmers' involvement in WUGs. This statement of intent should be underpinned by clear actions, such as providing targets for equal representation of women and men in these and other decision-making bodies, including in executive committees. To promote the active participation of women in WUGs, leadership and management training for women should be included as a project training component.

\section{Education and Training}

The government is currently implementing the Education Development Strategy of the Kyrgyz Republic, 2012-2020, with the aim of improving the quality of education delivery and infrastructure for girls and boys. The government is also responding to the reality that girls' higher educational attainment in the country often does not translate into formal economic employment and political participation due to sociocultural and economic factors. One of the objectives of the NAPGE 2012-2014 was to reduce gender imbalances in the labor market by diversifying the types of jobs undertaken by women and men. However, effective change was hindered by the low level of resources in this area, with the current level of government spending on education at just $6 \%-7 \%$ of the GDP.

The main objective of ADB's operations in the sector is to support the government in achieving a sustainable, gender-responsive transformation of the education system to ensure that men and women from all population groups are able to benefit from the opportunities 
created by growth (ADB 2011a). A priority is to improve the access of girls to STEM in TVET institutions and universities. A comprehensive GAP has been prepared with indicators that include improving the quality of curricula, teacher training, increasing attendance for boys and girls, and challenging gender stereotypes in TVET. An ADB gender monitoring report in July 2018 shows good progress against many of the indicators (ADB 2016b).

Key gender issues for ADB-funded education projects in the Kyrgyz Republic are the following:

\section{Addressing Gender Biases and Stereotypes in School Curricula and Materials}

Gender prejudices and discriminatory attitudes are often the result of behaviors and norms learned from a young age through social institutions, such as schools. Thus, educational institutions have a responsibility to challenge prescriptive and inequitable gender perceptions and to introduce alternative ideas of what is possible for both girls and boys. Despite gender parity in enrollment statistics, the country has been criticized by the CEDAW Committee and other actors for the gender stereotypes that often infiltrate educational materials and influence the choice of subject specialization for girls and boys.

In response, the ADB-funded Strengthening the Education System Sector Development (SESSD) Program supports education reform based on the Kyrgyz Republic Education Development Strategy 2020 through the delivery of high-quality education and training and by creating education that is demand-driven and responsive to the needs of the economy and the labor market. The program's GAP, therefore, targets the development of a genderaware curriculum and training materials. A gender analysis of textbooks was done and recommendations were made for improving their gender awareness. Quality teacher training for women teachers, school principals, and their deputies were conducted through the program. A total of 120 administrators, including 49 deputies of directors, from 30 innovative schools were trained in 2017 through two modules on gender issues. This included a promotion of the law on preventing early marriages. The SESSD program is classified as EGM.

The program's GAP also includes a specific indicator for creating more gender-aware curricula and processes of curricula development. Strategies include training programs and checklists for curriculum developers, textbook writers, and textbook manuscript evaluators; and training modules for artists and designers of textbooks that integrate gender equality and social inclusion issues (ADB 2018e).

\section{Creating Gender Awareness for Teachers and the Public}

The Second Vocational Education and Skills Development Project (SVESDP) program aims to address gendered perceptions that influence girls' choice of subjects in TVET and universities. Strategies include the introduction of gender quotas for STEM subjects, targeted training for girls, and media campaigns to help shift public attitudes. For example, gender-sensitive audio and video materials were produced, published, and broadcast nationwide. The Skilling and Entrepreneurship for Inclusive Growth Project was also approved in November 2017 with funding of $\$ 30$ million. The project focuses on the quality of vocational education, governance, and education financing. It will support (i) post-secondary curricula reform in technical and vocational education, (ii) the introduction of entrepreneurship education, and (iii) in-service 
teacher training. In 2020, a new \$30 million Post-Secondary and Higher Education Sector Reform Program will continue to implement reforms in the education sector.

\section{Entry Points for Gender Mainstreaming in Education}

Ensure processes and resources are in place to support gender-sensitive education. The current GAP is excellent in its scope and goals and can potentially contribute to gender transformation. However, it is essential to ensure the adequacy of financial and human resources for its implementation. Where possible, separate gender budgets should be prepared to avoid funds being diverted elsewhere. GFPs with decision-making power should also be appointed within school boards to promote accountability in gender commitments. Education of teacher-trainers and school administrators on gender-responsive teachinglearning processes, adequate facilities, and the creation of safe learning environments should be provided in a systematic way for all new teachers and to those who are already established.

Put systems in place to track progress and impacts. Effective monitoring and evaluation of the progressive, gender-aware strategies promoted by current ADB-funded programs, particularly SESSD and SVESDP, is vital to demonstrate the short- and longer-term benefits of such initiatives. This will also enable good practices to be scaled up and adapted for different educational establishments. An updated scan of labor market information should feed into the TVET curricular programs and strategies to assist both girls and boys in making subject choices that will meet the demands of potential future employers. A periodic dialogue with local industry partners and prospective employers could help inform the creation of internship opportunities in technical areas and well-paid sectors for female students. The collection of sex-disaggregated data and stories of change should form an integral part of monitoring. This should include employment data for female and male graduates. 


\section{Lessons and Conclusions}

\section{A. Addressing Gender Equality Issues in the Kyrgyz Republic}

The transition of the Kyrgyz Republic-from a former Soviet Union state to a market economy-has been challenging but the country is now experiencing a cautiously hopeful period of greater political stability and steady economic growth. There have been positive social impacts with clear implications for gender equality. The new Constitution promotes human rights for all and the formal mechanisms of the NGS, NAPGEs, and legislation such as the revised domestic violence law and the introduction of the $30 \%$ quota for women's political representation demonstrate a clear commitment to addressing gender-based inequalities. However, inadequate financial and human resources, and poor understanding of gender issues in government agencies and other institutions are preventing these from being fully realized in practice. The strengthening of conservative social and religious gender norms and ideas during the transition is also a cause for concern; these not only undermine women's potential for empowerment but also threatens their rights and body integrity in cases such as bride kidnapping, early marriage, and domestic violence.

The principles of equality are embedded in the Kyrgyz Republic Constitution and in the Gender Equality Law. The country's civil, penal, labor, and family codes also contain provisions that guarantee the equal rights of women and men. Gender equality principles have been incorporated in the NSSD (2013-2017), and in the National Strategy on Achieving Gender Equality (2012-2020). However, as noted earlier, the effective implementation of these policies is impeded by (i) the lack of political will to advance gender equality; (ii) a growing traditionalist and/or patriarchal discourse that questions the very principle of equality between women and men; (iii) inadequate funding for advancing women's rights, including no gender-responsive planning and budgeting at national and local levels; and (iv) the lack of institutional capacity of state and nonstate stakeholders to implement and monitor activities promoting gender equality.

To address critical gender issues that include (i) stereotyping, and women's limited participation in decision making and leadership positions; (ii) limited access to economic opportunities and key resources; and (iii) limited access to and poor public service delivery and gender-based violence, this CGA report makes the following recommendations to promote nondiscrimination, gender equality, and women's empowerment. 


\section{The Government of the Kyrgyz Republic should undertake the following:}

- Demonstrate a continued commitment to promoting gender equality and women's empowerment as an integral part of the government's development agenda, with gender equality integrated across laws, policies, and programs.

- Allocate adequate financial resources for the effective implementation of the National Gender Strategy (2012-2020), its NAPGE, and the national action plan on the implementation of the UN Security Council Resolution 1325.

- Ensure women's participation in decision making through enforced implementation of temporary special measures, such as quotas for the broader participation of women-including ethnic minority women-in public, economic, and political life and other areas at the local and national levels.

- Promote women's participation in local institutions dealing with natural resource management (water users associations; and local committees on pasture, fishery, and forestry management).

- Mainstream a gender perspective into the state's personnel policies at the national, municipal, and local levels, including recruitment, family-work balance policy, reward, promotion, and retirement policies.

- Strengthen the technical capacity of government ministries to conduct gender analysis in policy planning, program implementation, and monitoring and evaluation.

- Improve the collection and use of sex-disaggregated data to inform relevant policies and enhance monitoring in government programs.

- Ensure that women are involved in the development, implementation, monitoring, and evaluation of regional, local, and sectoral development strategies and programs. The barriers in accessing the information and the limited mobility of women and girls, disabled, and ethnic minority should be noted and addressed accordingly in projects and/or programs.

- Introduce legislative measures and special programs on the economic empowerment of women, including ensuring access to economic resources, economic education, and technologies.

\section{Key development actors-including ADB and the Government of the Kyrgyz Republic- should undertake the following:}

- Support gender-responsive architecture through awareness strategies at national, government, and community levels, including within school curricula. These strategies should communicate clearly why equality of rights and opportunities is integral to a well-functioning democracy. Awareness strategies should also highlight the potential economic opportunity costs of not supporting women's active engagement in the country's development beyond their roles as caregivers in the household.

- Continuously challenge and address social and cultural stereotypes on women's (secondary) role in the family and in society resulting in the promotion of discriminatory and traditionalist patriarchal practices.

- Support comprehensive monitoring of the implementation of laws and policies on gender, and evaluation of the impact of laws, policies, and programs on gender equality and women's and girls' rights, integrating gender-responsive budgeting and planning at the national, local, and sector levels. 
- Undertake actions to identify and address the systemic barriers to women's economic and political empowerment. In the case of the labor market, positive measures should include (i) holding employers to account for hiring and other practices that discriminate on the basis of gender; (ii) creating a supportive environment for girls and young women to study nontraditional subjects that will lead to well-paid careers within the new economy; (iii) providing adequate, affordable childcare and preschool amenities to enable women with caring responsibilities to enter or return to the workplace.

- Identify and actively support female role models who can inspire other women to run for posts in local or national government.

- Provide leadership training for girls and young women to help them build their confidence and skills needed for political involvement, and challenge the perception that men make better leaders than women.

\section{Improving Gender Mainstreaming in ADB Priority Sectors}

During 2013-2017, ADB focused on five key sectors within the Kyrgyz Republic: PSM, transport, energy, water and sanitation, and education. However, there has been rather uneven compliance with the ADB gender policy. A number of programs in the CPS 2013-2017 produced gender-responsive EGM and gender equity theme (GEN) programs with sustainable results in partner institutions and in the target sectors and communities. Good gender practices are evident in ADB-funded PSM programs. Although the initial phase of ICIP 1 was lacking in gender elements, future phases have all been classified as EGM, recognizing the importance of creating an enabling environment for female entrepreneurs and of boosting women's employment as part of a broader economic growth strategy. The WEDP, in particular, resulted in very positive outcomes for women's economic empowerment. There are also clear, genderresponsive examples in the water and sanitation sector. The CCDRWR is taking a strongly participative approach that aims to reflect the voices and needs of diverse male and female end users, while also focusing on gender-specific issues, such as increasing the resilience of women and girls in the face of climate-related weather events and disasters.

ADB has also contributed considerably to potentially gender transformative approaches in the country's education sector. The SESSD is taking on the vital task of challenging and changing gender biases and stereotyping through the gender-sensitive analysis and revision of school curricula and by the gender awareness of teaching staff. The SVESP is also progressive in its efforts to encourage girls to study STEM and other nontraditional subjects to increase their opportunities of landing in well-paid formal employment. These programs provide good practice examples and learning to inform and inspire the current CPS 2018-2020.

By contrast, ADB's support to the energy and transport sector programs has been far less successful in mainstreaming gender. There were indirect gender benefits in the energy sector programs, but these are often part of broader improvements to household connectivity. There were no targeted strategies to create women's employment opportunities in the rapidly expanding energy industry or to understand the specific needs of female and male users. Despite being the most significant sector for ADB support in the Kyrgyz Republic, with the largest proportion of funding, transport programs have so far been the most disappointing in 
terms of gender mainstreaming, with no gender elements in any of the regional and national roads projects. This will hopefully change with the introduction of the comprehensive GAP for the CAREC project. It will be crucial to ensure that adequate resources are committed to the implementation of the GAP, and that a dedicated gender specialist is appointed to support and oversee the process.

Key gender entry points are included in Section IV. Mainstreaming Gender in ADB Operations, under each of the sectors. However, it is important to reiterate that, for the CPS 2018-2020, the significant message is that women are primary end users of goods, services, and infrastructure; and that their perspectives must inform development programming in all priority sectors. Gender analysis must be conducted as a standard part of all program planning to mitigate against any possible harm and to identify opportunities to boost women's economic capacity through employment or training. Building gender awareness for staff and partners is a vital element of effective gender mainstreaming, as well as the involvement of gender specialists in ADB operations and in partner institutions. Finally, sharing learning across program portfolios should happen periodically for in-country teams and their partners to demonstrate what good, gender-responsive programming looks like, while results must be highlighted and lessons and areas for improvement are clearly identified. 


\section{References}

ADB. 2003. Gender and Development Framework and Policy. Manila.

2005. A Gendered Transition: Soviet Legacies and New Risks-Kyrgyz Republic.

Country Gender Analysis. Manila.

2006. Gender and the Law and Policy. Manila.

2008. Strategy 2020: The Long-Term Strategic Framework of the Asian Development Bank, 2008-2020. Manila.

2009. Report and Recommendation of the President to the Board of Directors: Issyk-Kul Sustainable Development Project. Manila.

2010. Sustainable Transport Initiative-Operational Plan. Manila. https://www.adb. org/documents/sustainable-transport-initiative-operational-plan.

2011a. Evaluation of the Social Sector (Education and Health) Assistance Program. Manila.

_. 2011b. Kyrgyz Republic: Investment Climate Improvement Program. Manila.

2012a. Country Assistance Program Evaluation. The Kyrgyz Republic: Evolving Transition to a Market Economy. Manila.

_.2012b. Gender Tool Kit: Public Sector Management. Manila. https://www.adb.org/ sites/default/files/institutional-document/33643/files/gender-tool-kit.pdf.

_.2012c. Gender Tool Kit: Energy - Going beyond the Meter. Manila. https://www.adb. org/sites/default/files/institutional-document/33650/files/gender-toolkit-energy.pdf.

-2012d. Report and Recommendation of the President to the Board of Directors: Second Vocational Education and Skills Development Project. Manila.

2013a. Understanding and Applying Gender Mainstreaming Categories: Tip Sheet No. 1. Manila.

2013b. Gender Tool Kit: Transport-Maximizing the Benefits of Improved Mobility for All. Manila. https://www.adb.org/sites/default/files/institutional-document/33901/ files/gender-tool-kit-transport.pdf (accessed on 20 November 2017).

_. 2013c. Country Partnership Strategy: Kyrgyz Republic, 2013-2017. Bishkek.

2013d. Gender Analysis (Summary). Country Partnership Strategy: Kyrgyz Republic, 2013-2017. Bishkek. https://www.adb.org/sites/default/files/linked-documents/cpskgz-2013-2017-ga.pdf.

2013e. Grant Assistance Report: Women's Entrepreneurship Development Project.

Project No. 46010-01. Manila. 
2013f. Report and Recommendation of the President to the Board of Directors: Central Asia Regional Economic Cooperation Regional Improvement of Border Services Project. Manila.

2014a. The Kyrgyz Republic Strategic Assessment of the Economy: Promoting Economic Growth. Manila.

2014b. Communication Technologies for Women Entrepreneurs: Prospects and Potential in Azerbaijan, Kazakhstan, the Kyrgyz Republic, and Uzbekistan. Manila.

_. 2014c. Gender Tool Kit: Micro, Small, and Medium Enterprise Finance and Development. Manila. https://www.adb.org/sites/default/files/institutionaldocument/34125/gender-tool-kit-mse-finance-development.pdf.

. 2014d. RETA 7563 Pilot Project. Promoting Gender-Inclusive Growth in Central and West Asia Project. Final Report on "Professional WO=MEN: Gender Mainstreaming of Technical Vocational Education and Training in Kyrgyz Republic.” Manila.

-2014e. Report and Recommendation of the President to the Board of Directors: CAREC Corridor 1 (Bishkek-Torugart Road) Project 3. Manila.

_ 2015. A Safe Public Transportation System for Women and Girls. Policy Brief. Manila. 2016a. ADB and the Kyrgyz Republic: Fact Sheet. https://www.adb.org/sites/default/ files/publication/59620/kgz-2016.pdf.

_.2016b. Kyrgyz Republic Education Sector GAP Monitoring Report. Bishkek. 2016c. Report and Recommendation of the President to the Board of Directors: Central Asia Regional Economic Cooperation Corridors 1 and 3 Connector Road Project. Manila. 2017a. Country Operations Business Plan: Kyrgyz Republic, 2018-2020. Manila. . 2017b. Key Indicators for Asia and the Pacific, 2017: Kyrgyz Republic. https://www.adb. org/sites/default/files/publication/357006/kgz.pdf.

_.2017c. Project Completion Report: Emergency Assistance for Recovery and Reconstruction. Manila.

-2017d. Project Report: Consolidated Report on Gender Expertise of PFIs under ADB Women's Entrepreneurship Development Project. Manila.

2017e. Report and Recommendation of the President to the Board of Directors: Summary Poverty Reduction and Social Strategy. Second Investment Climate Improvement Program (Subprogram 3). Manila.

2018a. Kyrgyz Republic, 2018-2022-Supporting Sustainable Growth, Inclusion, and Regional Cooperation. Country Partnership Strategy. Manila. https://www.adb.org/ sites/default/files/institutional-document/455921/cps-kgz-2018-2022.pdf

_. 2018b. Asian Development Bank and the Kyrgyz Republic-Fact Sheet. https://www. adb.org/publications/kyrgyz-republic-fact-sheet.

_.2018c. Strategy 2030: Achieving a Prosperous, Inclusive, Resilient, and Sustainable Asia and the Pacific. Manila.

_. 2018d. Kyrgyz Republic: Country Partnership Strategy Final Review Validation, 2013-2017. Manila. 
_. 2018e. Kyrgyz Republic Education Sector GAP Monitoring Report. Manila.

—. n.d. Gender Checklist in Agriculture. Manila. n.d. Gender Checklist: Water Supply and Sanitation. Manila. https://www.adb.org/ sites/default/files/publication/28735/gender-checklist-water.pdf.

—. n.d. Investment Climate Improvement Program (ICIP). 2008. Project Data Sheet. https://www.adb.org/projects/41544-012/main\#project-pds.

Alymbaeva, A., K. Almakuchukov, E. Nasritdinov, R. Rakhimov, and B. Zhu-makadyr kyzy. 2013. Debating Internal Migrations in Kyrgyzstan. In Voices from Central Asia, No. 9. Washington, DC: Eliott School of International Affairs, George Washington University. https://www.academia.edu/2899739/on_Internal_migration_in_Kyrgyzstan.

Arrow for Change. 2015. Gender Equality, Sexual and Reproductive Health and Rights, and the 2030 Sustainable Development Agenda: Moving Ahead at the National Level in Kyrgyzstan for Better Financing, Implementation, Monitoring and Accountability. https://arrow.org.my/wp-content/uploads/2018/10/pdf-4811/index.pdf.

Bankwork Network. 2018. Gender Inclusion in the EBRD Public Transport and Water Projects in Southern Kyrgyzstan. Bishkek.

Brody, A., J. Demetriades, and E. Esplen. 2008. Gender and Climate Change: Mapping the Linkages-A Scoping Study on Knowledge and Gaps. Brighton: BRIDGE/IDS.

Committee on the Elimination of Discrimination against Women (CEDAW). 2015. Concluding Observations, CEDAW/C/KGZ/CO/4. http://tbinternet.ohchr.org/_layouts/ treatybodyexternal/Download.aspx?symbolno=CEDAW\%2fC\%2fKGZ\%2fCO $\% 2 \mathrm{f} 4 \& \mathrm{~L}$ ang=en.

Childress, S. 2017. Plates and Dishes Smash; Married Couples Clash: Cultural and Social Barriers to Help-Seeking among Domestic Violence Survivors in Kyrgyzstan. Violence Against Women. 1-23. Sage. https://journals.sagepub.com/doi/ pdf/10.1177/1077801217722239.

Commercio, M. 2014. The Politics and Economics of Retraditionalization. Kyrgyzstan and Tajikistan Post-Soviet Affairs. 31 (6). pp. 529-56. https://www.tandfonline.com/doi/ abs/10.1080/1060586X.2014.p6870.

Dyldaev, M. 2017. Urbanization Processes in the Kyrgyz Republic. Case Study: The City of Bishkek. Studia UBB Geographia, LXII, 1. http://studiageographia.geografie.ubbcluj.ro/ wp-content/uploads/2017/07/dy.pdf.

Djanaeva, O. 2015. Rural Women's Association “Alga,” Kyrgyzstan. In E. Duban. 2016. Country Gender Assessment, Kyrgyz Republic. Unpublished draft for ADB.

Duban, E. 2016. Kyrgyz Republic Country Gender Assessment. Unpublished draft for ADB.

European Bank for Reconstruction and Development (EBRD). 2013. EBRD Special Climate Change Fund: Promoting Climate Resiliency of Water Supplies in Kyrgyzstan. https:// www.thegef.org/sites/default/files/project_documents/EBRD\%2520Kyrgyz\%2520SC CF\%2520ProDoc\%2520v1-1_1.pdf.

Equal Rights Trust. 2016. Looking for Harmony: Addressing Discrimination and Inequality in Kyrgyzstan. The Equal Rights Trust Country Report Series: 9. London. https://www. equalrightstrust.org/sites/default/files/ertdocs/Kyrgyzstan_EN_0.pdf. 
European Institute for Gender Equality. 2017. Gender Equality Index 2017-Measuring Gender Equality in the European Union 2005-2015. Vilnius. https://eige.europa.eu/ sites/default/files/documents/20177277_mh0517208enn_pdf.pdf.

Food and Agriculture Organization of the United Nations (FAO). 2016. National Gender Profile of Agricultural and Rural Livelihoods-Kyrgyz Republic. Country Gender Assessment Series. Rome.

Government of the Kyrgyz Republic. 2010. Kyrgyzstan's Constitution of 2010. Bishkek. https://www.constituteproject.org/constitution/Kyrgyz_Republic_2010.pdf?lang=en.

2012. National Action Plan on Gender Equality, 2012-2014. Bishkek.

-2013. National Sustainable Development Strategy for the Kyrgyz Republic, For the period of 2013-2017. Bishkek. http://www.lse.ac.uk/GranthamInstitute/wp-content/ uploads/laws/4242_EN.pdf.

_2015. National Action Plan on Gender Equality, 2015-2017. Bishkek.

_. 2018. National Action Plan on Gender Equality, 2018-2020. Bishkek.

Hoare, J. 2009. Development and Gender in Kyrygyzstan. Unpublished SRC Research Report. https://www.files.ethz.ch/isn/145095/Hoare_Devpt_Gender.pdf.

Homans, R. 2011. Women Entrepreneurship Development Project, Kyrgyz Republic, RSC-C20368 (KGZ). ADB internal document (material provided by Gulfia Abdullaeva).

Human Rights Watch. 2017. Kyrygyzstan: New Domestic Violence Law-Government Moves to Improve Response to Abuse. https://www.hrw.org/news/2017/05/10/kyrgyzstannew-domestic-violence-law.

Ibraeva, G., A. Moldosheva, and A. Niyazova. 2011. World Development Report 2012: Gender and Development Background Paper. Kyrgyz Country Case Study. Washington, DC: The World Bank.

International Monetary Fund (IMF). 2014. Kyrgyz Republic Poverty Reduction Paper, 2014-2017. Country Report No. 14/247. Washington, DC.

Joshi, M., and S. Childress. 2017. A National Survey of Attitudes toward Intimate Partner Violence among Married Women in Kazakhstan, Kyrgyzstan, and Tajikistan: Implications for Health Prevention and Intervention. Social Work in Health Care. 56: 4. https://doi.org/10.1080/00981389.2016.1268660.

Kuehnast, K. and N. Dudwick. 2002. Better a Hundred Friends than a Hundred Rubles? Social Networks in Transition-the Kyrgyz Republic. World Bank Economists Forum. Vol. 2. pp. 51-88.

Law and Development Partnership and the EBRD. 2015. Legal Barriers to Women's Participation in the Economy in the Kyrgyz Republic. London: EBRD.

Mayoux, L. and G. Mackie. 2008. A Practical Guide to Mainstreaming Gender Analysis in Value Chain Development. Addis Ababa: International Labour Organization.

Moldosheva, A. 2008. Violence against Women: Baseline Assessment. Bishkek: United Nations Population Fund.

Muldoone, R. and U. Casabonne. 2017. Gender Norms in Flux: Bride Kidnapping and Women's Civic Participation in the Kyrgyz Republic. Washington, DC: World Bank Group. 
National Council for Sustainable Development (NCSD). 2013. National Sustainable Development Strategy for the Kyrgyz Republic, 2013-2017. http://www.un-page.org/ files/public/kyrgyz_national_sustainable_development_strategy.pdf.

National Statistical Committee (NSC) of the Kyrgyz Republic. 2015a. Employed Population Aged 15 and Over by Activity and Sex. Bishkek: Government of the Kyrgyz Republic. 2015b. Women and Men of the Kyrgyz Republic: Compendium of Gender Disaggregated Statistics, 2011-2015. pp. 75-77. Bishkek: Government of the Kyrgyz Republic.

_.2015c. Results of Sample Time Use Surveys. Part 1. Bishkek. [in Russian].

_.2015d. Time Budget Survey. Bishkek. http://stat. kg/media/publication archive/030bc- dc0-e84e-41f4-9205-9becc51ffa9f.pdf.

—. 2016a. http: //www.stat.kg/en/statistics/naselenie. 2016b. Women and Men of the Kyrgyz Republic. Bishkek: Government of the Kyrgyz Republic.

-2017. Men and Women of the Kyrgyz Republic: Compendium of Gender Disaggregated Statistics, 2012-2016. Bishkek: Government of the Kyrgyz Republic.

NSC and United Nations Children's Fund (UNICEF). 2015. Kyrgyzstan Multiple Indicator Cluster Survey 2014, Final Report. Bishkek: National Statistical Committee of the Kyrgyz Republic and UNICEF.

NSC, Ministry of Health [Kyrgyz Republic], and ICF International. 2013. Kyrgyz Republic Demographic and Health Survey 2012. Bishkek, Kyrgyz Republic, and Calverton, Maryland, USA: NSC, MOH, and ICF International. https://dhsprogram.com/pubs/ pdf/FR283/FR283.pdf.

NGOs on Child Rights. 2014. Joint Submission to the UPR. Para. 3. http://www.ohchr.org/ EN/HRBodies/UPR/Pages/UPRKGStakeholdersInfoS21.aspx.

Piga, G., T. Novovic, and R. Mogilevskii. 2016. Common Country Assessment for the Kyrgyz Republic. Bishkek: UN in the Kyrgyz Republic. http://kg.one.un.org/content/dam/ unct/kyrgyzstan/docs/Library/Книга\%200OH_Eng.pdf.

Sayakbaev, T. and E. Mokrousova. 2014. Informal Employment in the Kyrgyz Republic. Bishkek: National Institute of Strategic Studies in the Kyrgyz Republic.

Scalise. E. and A. Undeland. 2016. Kyrgyz Republic Women and Community Pasture Management. Bishkek: Landesa and Center for Women's Rights. https://www.landesa. org/wp-content/uploads/2016-Best-Practices-Case-Kyrgyzstan.pdf.

Shahrashoub, R. and C. Miller. 1995. From WID to GAD: Conceptual Shifts in the Women and Development Discourse. United Nations Research Institute Occasional Paper Series. 1 (2). Geneva: United Nations Research Institute for Social Development.

Skinner, E. 2011. Gender and Climate Change: BRIDGE Cutting Edge Pack. Brighton: Institute of Development Studies.

Transport Corridor Europe-Caucasus-Asia (TRACECA). 2013. Logistics Processes and Motorways of the Sea II LOGMOS Master Plan-Annex 9.1. Country Profile. Baku. http://www.traceca-org.org/fileadmin/fm-dam/TAREP/65ta/Master_Plan/MPA9.1KY. pdf. 
United Nations (UN). 2016. No One Left Behind-Evaluating the SDGs with an EquityFocused and Gender Equality Lens. http://kg.one.un.org/content/unct/kyrgyzstan/en/ home/news/kg-news/2016/no-one-left-behind--evaluating-the-sdgs-with-an-equityfocused-a.html.

United Nations Development Programme (UNDP). 2013. Climate Profile of the Kyrgyz Republic. Bishkek. http://www.kg.undp.org/content/dam/kyrgyzstan/Publications/ env-energy/kgz_Kyrgyzstan\%20Climate\%20profile_ENG_for\%20web-opt.pdf.

2016a. Case Study on Combating Gender Inequality in Political Participation in Kyrgyzstan. Regional Human Development Report. Progress at Risk. Inequalities and Human Development in Eastern Europe, Turkey, and Central Asia. Istanbul. http:// www.eurasia.undp.org/content/rbec/en/home/library/human_development/regionalhuman-development-report-2016--progress-at-risk.html.

_. 2016b. Briefing Note for Countries on the 2016 Human Development Report, Kyrgyzstan. New York. http://hdr.undp.org/sites/all/themes/hdr_theme/countrynotes/KGZ.pdf.

-2016c. Trade and Human Development in Kyrgyzstan: National Human Development Report. New York.

2017. Comparative Gender Profile. The Kyrgyz Republic. http://www.kg.undp.org/ content/kyrgyzstan/en/home/library/womens_empowerment/comparative-genderprofile-2017--kyrgyz-republic.

2018a. Human Development Indices and Indicators. 2018 Statistical Update. http://hdr. undp.org/sites/default/files/2018_human_development_statistical_update.pdf.

_. 2018b. Human Development Reports. Gender Inequality Index. http://hdr.undp.org/ en/composite/GII (accessed October 2018).

United Nations Environment Programme (UNEP). 2016. Third National Communication of the Kyrgyz Republic under the UN Framework Convention on Climate Change. Bishkek. https://unfecc.int/files/national_reports/non-annex_i_natcom/application/pdf/nc3_ kyrgyzstan_english_24jan2017.pdf.

2017. Gender, Poverty, and Environment in Rural Kyrgyzstan: Issues of Natural Resource Management, Biodiversity and Environmental Degradation. http://www. kg.undp.org/content/dam/kyrgyzstan/Publications/gender/Gender,\%20poverty\%20 and\%20environment_2017.pdf.

United Nations Population Fund (UNFPA). 2014. Child Marriage in Kyrgyzstan. Fact Sheet. https://www.girlsnotbrides.org/resource-centre/unfpa-child-marriage-countryprofilekyrgyz-republic/.

United Nations Children's Fund (UNICEF). 2008. Out-of-School Children in the Kyrgyz Republic. Bishkek.

—. 2015. Kyrgyzstan Multiple Cluster Survey, 2014: Final Report. Bishkek.

UN Women. 2017. New Progressive Law on Domestic Violence Adopted in Kyrgyzstan. http://www.unwomen.org/en/news/stories/2017/5/news-new-progressive-law-ondomestic-violence-adopted-in-kyrgyzstan.

UN Women/UNFPA. 2016. Gender in Society Perception Study: National Survey Results. Bishkek. 
World Economic Forum (WEF). 2017. Global Gender Gap Index, Kyrgyz Republic. http:// www3.weforum.org/docs/WEF_GGGR_2017.pdf.

World Bank. 2013. Integrating Gender Considerations into Energy Operations. Energy Sector Management Assistance Program (ESMAP) Knowledge Series 014/13. Washington, DC. https://openknowledge.worldbank.org/bitstream/handle/10986/17479/765710ESMOP 1230to0Energy0Operations.pdf? sequence $=1$ \&isAllowed $=\mathrm{y}$. 2014. Power Sector Policy Note for the Kyrgyz Republic: Final Report, Energy Sector Management Assistance. Bishkek.

2015. Kyrgyz Republic Partnership Program Snapshot. Washington, DC. http:// documents.worldbank.org/curated/en/206341486990416988/pdf/111966-WPPUBLIC-KYRGYZRE.pdf.

—. 2016. Kyrgyz Republic. https://data.worldbank.org/country/kyrgyz-republic (accessed October 2018).

_. 2017. Kyrgyz Republic Economic Update. Fall/Winter, 2017, http://documents. worldbank.org/curated/en/727401517229479407/pdf/122978-NWP-PUBLIC-Kyrgzno-6-add-series.pdf.

_. n.d.a. Gender Equality and Energy. https://www.esmap.org/sites/esmap.org/files/ DocumentLibrary/Gender_Energy_M03.pdf.

—. n.d.b. Kyrgyz Republic Country Profile. http://databank.worldbank.org/data/views/ reports/reportwidget.aspx?Report_Name=CountryProfile\&Id=b450fd57\&tbar=y\&dd=y \&inf $=\mathrm{n} \& \mathrm{zm}=\mathrm{n} \&$ country=KGZ .

n.d.c. GDP (current US\$)-Kyrgyz Republic. https://data.worldbank.org/indicator/ NY.GDP.MKTP.CD?locations=KG. 


\section{namonon \\ Gender Entry Points and Design Features in ADB's Priority Sectors}

\section{Transport}

Urban transport - Design transport infrastructure with gender-responsive physical design features that meet women's specific needs and promote universal access (e.g., (i) pram-friendly sidewalks, walkways, and pedestrian crossings; (ii) well-lit, all-weather bus stops; (iii) separate waiting spaces and/or women-only spaces in terminals; and (iv) street lights and allocated space for parked baby carriages).

- $\quad$ Provide separate male and/or female toilets and larger capacity female toilets at stations.

- Invest in safety features to reduce the risk of harassment for women users (e.g., (i) separate entrances and ticketing queues; (ii) women-only waiting areas; (iii) separate buses or train carriages; (iv) reserved seats; (v) lighting in stations; and (vi) panic buttons at stations, in trains, and in buses).

- Build safe and accessible pedestrian sidewalks, safe crossings, and street lighting as part of urban road and public transport improvement projects.

- Train public transport staff and local police (e.g., station attendants, drivers, and inspectors) on sexual harassment awareness, how to respond to observed situations of sexual harassment, and how to address complaints of harassment from the user public.

- Establish public transport schedules and pricing systems that respond to the needs of women users, including affordable off-peak, multiple trip, and group traveler ticketing.

- $\quad$ Set targets to ensure women's participation in trainings for skilled work related to providing or managing urban transport services.

- Set employment targets for women in construction and higher-skilled urban transport sector jobs generated by the project, such as station attendees, ticket collectors, drivers, and inspectors.

- Promote women's livelihoods and entrepreneurship around public transport hubs (e.g., allocation of reserved shop spaces at stations for women's businesses).

- Build the capacity of executing and implementing transport agency staff, including transport planning officials, on gender issues in urban transport and on the mobility needs of women.

Rural roads

- $\quad$ Collect and monitor sex-disaggregated transport and travel pattern statistics (with baseline) and carry out periodic surveys of public transport user demands in rural areas.

- Conduct community consultations with women and men (separately as appropriate), to identify and respond to local transport needs.

- Use gender analysis to plan and locate road alignments, including feeder roads, footpaths, and footbridges.

- Invest in feeder roads, footpaths, and footbridges where need exists.

- Design and implement gender-responsive road physical designs (e.g., roadside rest points, roadside market facilities, and wider and sealed road shoulders for walking and nonmotorized transport.

- Facilitate gender-responsive and affordable local public transport along improved roads (e.g., with safe pick-up and/or drop-off points conveniently located for women's access, schedules to suit women's different needs, and affordable and flexible fares). 


\section{Appendix Table continued}

- Prioritize nonmotorized transports and intermediate means of transport (IMTs) in transport planning; design IMTs to fit women's size and strength; and train women on how to operate, maintain, and repair IMTs.

- Where socially acceptable, consider the provision of bicycles for improving women's mobility and making it easier for girls to safely reach and attend school with reduced risk of gender-based violence en route.

- $\quad$ Plan and design rural roads for safe pedestrians use (walking lanes and crossings).

- $\quad$ Promote the use of community-based labor (e.g., roadside maintenance).

- Train women in areas for ancillary employment (e.g., rickshaw or bicycle repairs).

- $\quad$ Set targets for women's employment during construction and postconstruction.

- $\quad$ Ensure that gender targets and physical design features are specified in bidding documents for contractors, considering equipment-based versus labor-based techniques.

- $\quad$ Establish community road maintenance and safety committees with quotas to ensure the involvement of local women.

- $\quad$ Encourage women into higher-skilled jobs by providing on-the-job training (e.g., as surveyors, road safety auditors, and heavy equipment operators).

- Provide gender-responsive, HIV/AIDS, and human trafficking awarenessraising activities to the contractors and local communities.

- Target women for road safety awareness and implement road engineering measures to enhance road safety (e.g., traffic-calming devices, such as speed humps, use of local area traffic management devices, traffic signage, and manual or controlled pedestrian crossings).

National highways
- $\quad$ Set targets for women and/or women's groups to be consulted in preparatory surveys and assessments to inform project design.

- Plan highway and provincial road alignments to link to feeder roads, or directly pass close to schools, health centers, markets, and other key facilities of importance to women's gender roles and daily activities.

- Include female targets for all employment opportunities generated by the project (e.g., set percentage of women to be employed in civil works, toll collection staff, and supervisors).

- Incorporate gender-responsive physical designs along highways, such as road humps and roundabouts in populated areas, well-lit separate toilets at rest stops, and community complexes.

- Avoid unnecessary relocation of roadside economic activities and promote economic opportunities for women, such as provision of small and safely designed market stall areas at rest stops.

- Promote bus services to maximize the use of national highways and provincial roads by wider population.

- Identify opportunities to include a separate component or complementary project to benefit women, such as rural access roads, and income-generating activities or skills training to maximize the benefits of connectivity for women.

- Improve and rehabilitate access routes to highways, focusing on pedestrians and two-wheelers (e.g., dedicated pedestrian and/or two-wheeler lanes close to settlement areas).

- $\quad$ Provide separate human trafficking and HIV/AIDS awareness and behavior change communication programs for contractors and surrounding local communities, targeting young women, entertainment workers, truck drivers, and other at-risk groups. 


\section{Appendix Table continued}

Railways

\begin{tabular}{|l}
\hline Energy policy \\
\hline $\begin{array}{l}\text { Institutional } \\
\text { capacity of } \\
\text { energy agencies } \\
\text { and utilities }\end{array}$ \\
\hline
\end{tabular}

- Consult with potential female passengers on appropriate alignment of train line, location of train stations, and access to stations for their convenience and needs.

- $\quad$ Provide safe and secure rail stations and station access, with appropriate lighting and emergency panic buttons on trains.

- $\quad$ Provide separate female spaces where appropriate (e.g., separate ticketing queues, waiting areas, and train seating or carriages).

- $\quad$ Provide other gender-responsive physical design and universal access features for passenger carriages (e.g., space for parking baby carriages, appropriate height steps or level entry onto trains, and handle bars suited to the average height of women).

- Introduce flexible and affordable ticketing and train schedules for off-peak and multiple use to accommodate trip-chaining patterns of women.

- $\quad$ Provide separate male and female toilets and larger capacity female toilets at railway stations and on trains.

- Incorporate a gender perspective into station development plans, including promoting economic opportunities. (e.g., allocate reserved shop spaces in railway stations for women-owned businesses.

- Train railway and station staff on sexual harassment awareness, how to respond to observed situations of sexual harassment, and how to address complaints of harassment from the user public.

- Implement gender-sensitive sexual harassment campaigns for the public.

- Set targets for female employment in construction.

- $\quad$ Set targets for female employment in new railway jobs and provide women with equal access to on-the-job training (e.g., as railway station attendants, ticket booth operators, station managers, train drivers, ticket collectors, and railway operations and maintenance).

- Ensure that railway-related resettlement ensures equal rights for women and special assistance for women who may be particularly vulnerable.

- $\quad$ Provide support to women workers during privatization of railway operations through up-skilling training for reemployment (Box 6).

\section{Energy}

- Integrate gender elements and/or gender-responsive approaches in new and revised energy policies.

- Build gender awareness of energy sector policy makers through (i) targeted training programs to promote gender awareness; (ii) policy dialogue;

(iii) dialogue among government agencies, energy utilities, and women's organizations; and (iv) lateral learning.

- Train government and utility staff in (i) key gender issues in risk mitigation strategies and social safeguards, (ii) new energy technologies, and (iii) international standards and practice.

- Adopt a gender-equal human resources management strategy based on the implementation and application of gender equity laws and regulations in the energy sector (e.g., targets for (i) increasing the proportion of female staff and managers, (ii) establishing a gender-sensitive working environment, (iii) raising awareness of all staff on sexual harassment, and (iv) other forms of gender-based violence against women).

- Develop and update a sex-disaggregated project management database.

- Train project staff on effective implementation and monitoring of project gender features and project gender action plan. 


\section{Appendix Table continued}

Energy access

Energy-based enterprises

- $\quad$ Extend grid to widen energy access to poor households, especially those in the rural areas.

- Ensure affordability for the poor households (which often include households headed by women) through (i) free or affordable credit for up-front household connection costs (pole to house and inside household wiring), (ii) automatic eligibility for up-front household connections for poor households, (iii) revolving funds to support access for the poor, (iv) tariff levels set to reflect poor women's income levels, and (v) genderinclusive public consultation to assess women's opinions and preferences on affordability issues.

- $\quad$ Educate women and men about the new opportunities available for energybased enterprises and livelihoods.

- $\quad$ Partner with national and local nongovernment organizations (NGOs) to implement pilot livelihood programs that include (i) training for women in the use of labor-saving end-use energy technologies; (ii) access to appropriate microcredit services, grants, and/or concessional loans; (iii) finance and business management; and (iv) market access and marketing strategies.

- Conduct technical training on energy-based entrepreneurship widely to local NGOs to promote their greater participation in the energy sector.

- Promote women's entrepreneurship to serve newly emerging renewable energy markets, and the gaps in energy markets left unserved by the private sector.

- Provide incentives to improve the profitability of women entrepreneurs, such as tax benefits, public funding, energy equipment rebates, microcredit, and small and medium-sized enterprise financing. Employment/
economic
opportunities

\section{Improved} service delivery

Gendersensitive education programs
- Set targets for women's employment in project construction activities where possible.

- Provide technical and vocational training for women to promote women's employment (e.g., as technicians, in routine operation and maintenance, meter readers, and electricians).

- Partner with education service providers, such as vocational and/or technical training institutes and colleges, to implement gender-inclusive technical training programs.

- Set up scholarship programs to promote girls' education in nontraditional sectors, such as engineering.

- Implement core labor standards and/or appropriate labor laws on equal employment opportunities, equal pay for work of equal value, and women's on-the-job health and safety.

- Provide separate facilities for women, including separate toilets, rest rooms, and childcare facilities, in project sites.

- Develop user-education programs and modules targeted at women and men on the safe and efficient use of electricity and end-use technologies specifically targeted and relevant to women's household chores and economic activities; promote women's role as energy efficiency advocates; conduct awareness-raising activities on consumer entitlements, rights, and responsibilities; initiate linkages with gender equity policies, strategies, and laws; and identify conflict management and resolution provisions.

- Identify instruments and mechanisms to minimize power shortages and outages; improve service delivery to the poor, rural households, and communities, such as health clinics and schools; and improve the delivery of pumped water, and the provision of street lighting. 


\section{Appendix Table continued}

Genderresponsive CSR
- Develop and conduct community development programs for the families of employees and/or nearby communities, such as community development service center, vocational training for women, micro- and small enterprise development for services, reproductive health and family planning awareness programs, and cultural and recreational activities for women and children.

- Support scholarship programs especially targeted at increasing girls' enrollment in engineering and technical courses.

- Improve women's mobility and safety in power plant areas and in the community at large, including through investments in street lighting.

- Enhance and institutionalize gender-equitable human resources management.

- $\quad$ Provide gender training for management and staff.

$\begin{aligned} & \text { Energy access } \\ & \text { for the rural } \\ & \text { poor }\end{aligned}$

Women's
participation in
decentralized
community-
managed
distribution
models

- Extend grid to cover poor households in the rural areas.

- Ensure affordability through free or affordable credit for up-front household connections costs for rural poor households; automatic eligibility for up-front household connections for rural poor households headed by women; revolving funds to support rural poor; tariff levels to improve affordability and reflect rural women's income levels; and inform and consult rural poor women on affordability issues.

- Increase women's participation in electricity cooperatives, in users' groups and/or committees; and set targets to promote women's participation.

- Train women to be employed as system operators, technicians, managers, account staff, and others; include subjects on business management, energy efficiency, technical standards, design and maintenance of distribution networks, operation and maintenance, and safety.

- Conduct gender-sensitive activities on community entitlements, rights, and responsibilities, such as gender equity laws and regulations, energy sector regulations, and conflict management and resolution mechanisms.

- Provide gender training for electricity cooperatives and/or committees and user groups.

- Develop and implement gender-sensitive user-education programs for rural consumers.

- Educate women and men on the new opportunities to increase productivity and the value of their outputs, reduce postharvest losses in sustainable agricultural production and processing, and on nonagricultural cottage and village-level industries.

- Introduce new, clean technologies that can have a major impact on women's workload (e.g., agro-processing, food preparation, and household chores), and promote women's enterprises in new markets that emerge with energy access.

- Transfer skills to rural poor women by training them as village technicians, and providing them with jobs and livelihoods in the sustainable operation and maintenance of household village-level systems.

Energy-
based rural
entrepreneurship

- $\quad$ Partner with local and national NGOs to pilot interventions, such as training women in the use of nonpolluting and time-saving technologies, energy-efficient and sustainable agricultural production methods; enabling women to access capital through microcredit services; training in finance and business management; and market access information and marketing strategies.

- $\quad$ Provide capacity development to local NGOs so they could participate in the emerging renewable energy sector. 


\section{Appendix Table continued} Improved access
to renewable energy systems

\section{Women as service providers in renewable energy}

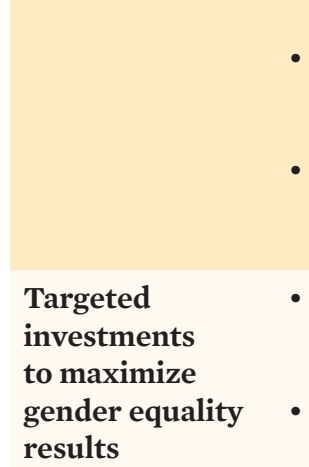

- Provide remote rural households that cannot be economically connected to national electricity grids with alternative energy supplies, such as off-grid, dispersed, renewable energy systems especially targeted for household energy use (e.g., small to micro hydro systems, solar photovoltaic home systems, etc.).

- Develop gender-inclusive, sustainable operational models for the decentralized operation and maintenance (O\&M) of these systems based on women's participation; include training for women in the new technology as system operators, technicians, and O\&M crew.

- Provide affordable options to offset the high, one-time initial cost of renewable energy technology and systems for women and low-income consumers through mechanisms, such as capital grants, consumer credit and/or microfinance, and others.

- Educate and raise awareness among women and men of the new opportunities due to the introduction of renewable energy systems (e.g., biogas plant construction masons, maintenance crop planting and animal breeding for biomass waste management, solar assembly and installation of stand-alone solar photovoltaic systems and solar panels, and others).

- Train rural women as village technicians in the construction, assembly, and routine O\&M of renewable energy systems, and set targets for women's participation.

- $\quad$ Provide targeted incentives to support women's entry as energy suppliers in the emerging renewable energy market, such as microfinance, small and medium-sized enterprise financing, tax benefits, and others.

- Invest in renewable energy technologies for street lighting, solar lamps to improve women's mobility and reduce women's vulnerability, or solar lanterns for girls and boys to improve gender gaps in education.

- Identify women's preferences in the design, use, and installation of renewable energy technologies, especially at the household and community levels, to ensure that the technologies contribute to reducing women's workloads.

\section{Water Supply and Sanitation}

Policy and institutional capacity development

Women's participation in decision-making
- Incorporate gender dimensions in new water legislation and/or policies

- Implement capacity building of staff, consultants, and NGOs in subproject social assessment and social preparation, and in gender awareness and participatory methodologies.

- Provide targets for the equal representation of men and women in decisionmaking bodies, such as in water user groups (WUGs).

- Set a mandatory number of women in the executive committees of WUGs.

- If necessary, form separate women's committees.

- To promote the active participation of women in WUGs, make leadership and management training for women one of the project training components.

- $\quad$ Provide capacity building for beneficiaries in subproject planning and implementation; financial and organizational management; and monitoring and evaluation (M\&E) training on technical, financial, and organizational matters.

- Identify organizations that could facilitate women's participation during implementation and M\&E. 


\section{Appendix Table continued}

\begin{tabular}{|c|c|}
\hline $\begin{array}{l}\text { Gender elements } \\
\text { in infrastructure } \\
\text { and services }\end{array}$ & $\begin{array}{l}\text { - Incorporate the preferences of men and women in the community on issues } \\
\text { such as (i) number and location of facilities (e.g., wells, pumps, latrines); } \\
\text { (ii) sharing vs. individual arrangement of facilities; (iii) type of wells, water } \\
\text { pumps, taps, etc.; (iv) type of latrines and other sanitary facilities (note } \\
\text { that where female seclusion is the norm, separate facilities are preferred to } \\
\text { shared ones); (v) type of acceptable intermediary means of water transport } \\
\text { (e.g., bullock cart, bicycles, mules, and others). } \\
\text { Incorporate the preferences of men and women in the community on } \\
\text { (i) financing arrangement (e.g., level of fixed cost and O\&M fees, cash vs. } \\
\text { in-kind/labor contribution); and (ii) possible preferential treatment for the } \\
\text { very poor, households with female heads, and other disadvantaged families. }\end{array}$ \\
\hline $\begin{array}{l}\text { Economic } \\
\text { opportunities } \\
\text { for women }\end{array}$ & $\begin{array}{l}\text { - During construction, ensure work conditions that are conducive to women's } \\
\text { participation (e.g., gender-equal wage rates, toilet, and childcare facilities). } \\
\text { - Consider seasonal labor demand in scheduling civil works. } \\
\text { - If appropriate, set a minimum percentage of female laborers and prohibit } \\
\text { the use of child laborers in the civil works contract. } \\
\text { Identify ways to link up with income generation, literacy, and other } \\
\text { activities to support an integrated approach to poverty reduction and } \\
\text { women empowerment (e.g., link up with ongoing or future microcredit } \\
\text { projects, dissemination of information on available services, with these as } \\
\text { project components). } \\
\text { For O\&M, provide training and appoint female pump operators, caretakers, } \\
\text { and water source monitors, where possible. }\end{array}$ \\
\hline $\begin{array}{l}\text { Sanitation and } \\
\text { hygiene }\end{array}$ & $\begin{array}{l}\text { Provide targets for women as active agents, while also ensuring the } \\
\text { involvement of male leaders. } \\
\text { Develop a program of community hygiene education and awareness raising. } \\
\text { Consider the types of media to be used depending on the target group } \\
\text { (e.g., teacher training, school curriculum, posters, billboards, and radio). } \\
\text { Raise community awareness of any possible health hazards caused by the } \\
\text { transport of water. }\end{array}$ \\
\hline $\begin{array}{l}\text { Staffing and } \\
\text { budgeting }\end{array}$ & $\begin{array}{l}\text { - } \quad \text { Provide gender-awareness training for all project staff. } \\
\text { - } \quad \text { Eire more female project staff. } \\
\text { (e.g., training budget, and consulting service budget for women's } \\
\text { organizations). }\end{array}$ \\
\hline $\begin{array}{l}\text { Monitoring and } \\
\text { evaluation }\end{array}$ & $\begin{array}{l}\text { - Develop a feedback mechanism where both male and female beneficiaries } \\
\text { have a voice. } \\
\text { Disaggregate all relevant indicators by gender (e.g., level of water supply } \\
\text { and sanitation (WSS) use and awareness among males and among females, } \\
\text { level of satisfaction, patterns of use, access rates, extent of service coverage, } \\
\text { awareness of hygienic practices, time saved in collecting and/or carrying } \\
\text { water, complaints and/or grievances, and others. }\end{array}$ \\
\hline
\end{tabular}




\section{Kyrgyz Republic Country Gender Assessment}

This country gender assessment (CGA) provides a comprehensive, up-to-date gender analysis of key socioeconomic areas in the Kyrgyz Republic. It reviews progress, identifies gaps in gender mainstreaming, and provides key recommendations for future planning in different sectors. The 2010 amended Constitution of the Kyrgyz Republic enshrines the principles of inalienable human rights and gender equality, but it is yet to fully recognize discrimination on the grounds of sexual orientation, gender identity, or disability. Although the country has achieved near gender parity in enrollment and literacy rates, it fares poorly in key global indicators concerning women. This report will be of primary interest to development partners designing or undertaking projects in the Kyrgyz Republic and the Central Asia region.

The Asian Development Bank initiates CGAs to map key gender equality issues, focusing on sectors supported by the bank's funding. This is the second CGA for the Kyrgyz Republic, following the first one published in 2005.

\section{About the Asian Development Bank}

ADB is committed to achieving a prosperous, inclusive, resilient, and sustainable Asia and the Pacific, while sustaining its efforts to eradicate extreme poverty. Established in 1966, it is owned by 68 members -49 from the region. Its main instruments for helping its developing member countries are policy dialogue, loans, equity investments, guarantees, grants, and technical assistance. 